SUBSTANCE FLOW ANALYSIS OF MERCURY IN TURKEY FOR POLICY DECISION SUPPORT

A THESIS SUBMITTED TO

THE GRADUATE SCHOOL OF NATURAL AND APPLIED SCIENCES OF

MIDDLE EAST TECHNICAL UNIVERSITY

BY

DIDDEM CIVANCIK

IN PARTIAL FULFILLMENT OF THE REQUIREMENTS

FOR

THE DEGREE OF MASTER OF SCIENCE

IN

ENVIRONMENTAL ENGINEERING

FEBRUARY 2015 

Approval of the thesis:

\section{SUBSTANCE FLOW ANALYSIS OF MERCURY IN TURKEY FOR POLICY DECISION SUPPORT}

submitted by DİDEM CIVANCIK in partial fulfillment of the requirements for the degree of Master of Science in Environmental Engineering Department, Middle East Technical University by,

Prof. Dr. Gülbin Dural Ünver

Dean, Graduate School of Natural and Applied Sciences

Prof. Dr. Dilek Sanin

Head of Department, Environmental Engineering

Prof. Dr. Ülkü Yetiş

Supervisor, Environmental Engineering Dept., METU

\section{Examining Committee Members}

Prof. Dr. Göksel N. Demirer

Environmental Engineering Dept., METU

Prof. Dr. Ülkü Yetiş

Environmental Engineering Dept., METU

Prof. Dr. Gürkan Karakaş

Chemical Engineering Dept., METU

Assoc. Prof. Dr. Emre Alp

Environmental Engineering Dept., METU

Gülsen Avaz, M.Sc.

Researcher, TÜBİTAK MAM

Date: February 5, 2015 
I hereby declare that all information in this document has been obtained and presented in accordance with academic rules and ethical conduct. I also declare that, as required by these rules and conduct, I have fully cited and referenced all material and results that are not original to this work.

Name, Last Name: Didem CIVANCIK

Signature 


\title{
ABSTRACT \\ SUBSTANCE FLOW ANALYSIS OF MERCURY IN TURKEY FOR POLICY DECISION SUPPORT
}

\author{
Civanc1k, Didem \\ M.S., Department of Environmental Engineering \\ Supervisor: Prof. Dr. Ülkü Yetiş
}

February 2015, 121 pages

Identification and quantification of mercury flows in Turkey is essential for better policy development regarding to the implementation of water-related legislation. To this end, in this study, substance flow analysis (SFA) of mercury in Turkey was conducted in order to identify and quantify mercury releases to different environmental compartments and help policy decision makers to better understand their options to reduce mercury flows. For the quantification of mercury flows, United Nations Environment Programme (UNEP) Mercury Toolkit, which was develop by UNEP Chemicals Branch with the aim of assisting countries to develop their own mercury inventory, was used. Results of the study showed that a total of 34.61 tons of mercury is released annually from the activities in Turkey to different environmental compartments. It was found that the most of the mercury releases were to the atmosphere (74\%) and relatively smaller amounts were to land $(21 \%)$ and to water (5\%). Mercury naturally found in the lithosphere was found to be responsible for most of the releases while intentional mercury uses have smaller shares and decreasing importance because of the phasing out of mercury.

Keywords: Substance Flow Analysis, SFA, Turkey, UNEP Mercury Toolkit, Mercury Inventory 


\title{
ÖZ
}

\section{POLITIKA GELIŞTIRME AMAÇLI TÜRKIYE'DE CIVANIN MADDE AKIŞ ANALIZI}

\author{
Civancık, Didem \\ Yüksek Lisans, Çevre Mühendisliği Bölümü \\ Tez Yöneticisi: Prof. Dr. Ülkü Yetiș
}

Şubat 2015, 121 sayfa

Türkiye'deki civa akışının saptanması ve sayıca belirlenmesi su ile ilgili mevzuatın uygulanması açısından önem taşımaktadır. $\mathrm{Bu}$ amaçla, farklı çevresel kompartmanlara olan civa salınımlarının tespit edilmesi ve politika belirleyicilere bu salınımları azaltmaya yönelik yapılması gerekenler için yol gösterilmesi için bu çalışmada, civanın Türkiye'de madde akış analizi yapılmıştır. Civa akışlarının sayıca belirlenmesi için Birleşmiş Milletler Çevre Programı (BMÇP), Kimyasallar Şubesi tarafından ülkelerin kendi civa envanterlerinin oluşturulmasına yardımcı olmak amacıyla geliştirilmiş "Mercury Toolkit" isimli program kullanılmıştır. Çalışma sonucunda, Türkiye'deki aktivitelerden farklı çevresel kompartmanlara toplamda yıllık 34.61 ton civanın salındığı bulunmuştur. Bu salınımın büyük bir oranının (\%74) havaya, daha küçük miktarların toprağa (\%21) ve suya (\%5) olduğu görülmüştür. Litosferde doğal olarak bulunan civanın bir çok önemli salınıma kaynak olduğu bulunurken, sanayi ve ürünlerde kasitlı olarak kullanılan civanın bu salınımlara daha az katkıda bulunduğu ve salınımlara olan katkısının, civanın yavaş yavaş kullanımdan kaldırılmasından dolayı giderek önemini kaybetmekte olduğu tespit edilmiştir.

Anahtar Kelimeler: Madde Akış Analizi, MAA, Türkiye, UNEP Mercury Toolkit, Civa Envanteri 
To mum and dad, 


\section{ACKNOWLEDGEMENTS}

Foremost, I would like to express my sincere appreciation and gratitude to my supervisor Prof. Dr. Ülkü Yetiş for her excellent guidance, knowledge, continuous support and friendship. I am truly fortunate to have had the opportunity to work with her. I could not have imagined having a better mentor for my study.

Besides my supervisor, I would like to thank to my examination committee members, Prof. Dr. Göksel N. Demirer, Prof. Dr. Gürkan Karakaş, Assoc. Prof. Dr. Emre Alp and Gülsen Avaz for their valuable contributions and insightful comments.

I would also like to thank to my dear friend Cansu Karakaş for her support, help and friendship, in other words, standing by me through out of the study. Without her, it would be very hard and boring.

I am grateful to my fellow roommates and friends, Fadime Kara Murdoch, Berkay Çelebi and Sema Yurdakul for their support, encouragement, friendship and giving joy to my days at METU. Also, I would like to thank to Dr. Robert Murdoch for his support and friendship.

I would like to express my thanks to my dear parents, Ferda and Levent Civancik for supporting me at every stage of my life with their endless love. I am also grateful for their patience, trust and understanding. Nothing would have been possible without them.

Finally, I would like to thank to Emre Uslu. He was always there through the good and bad times with his love, friendship and support. 


\section{TABLE OF CONTENTS}

ABSTRACT

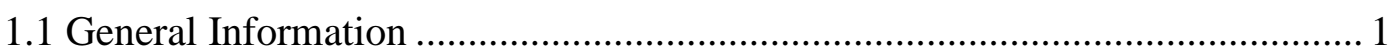

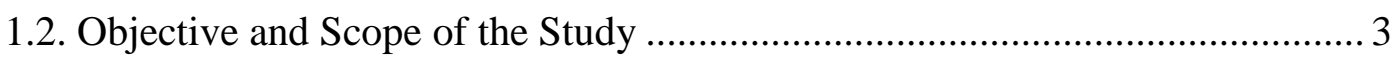

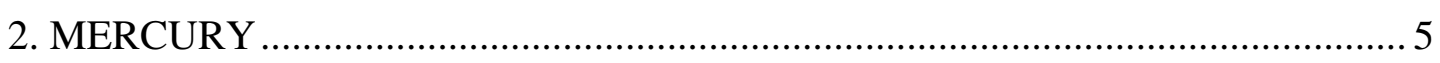

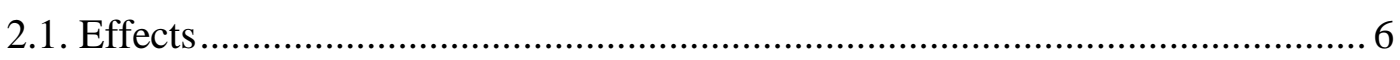

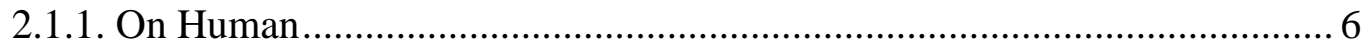

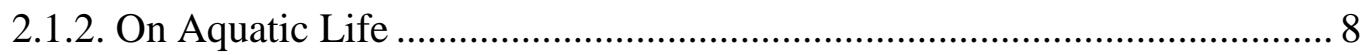

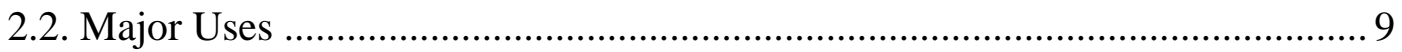

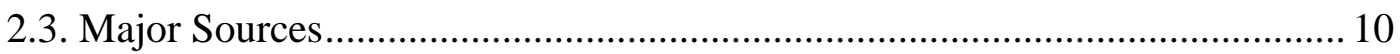

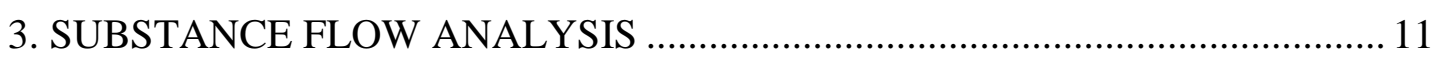

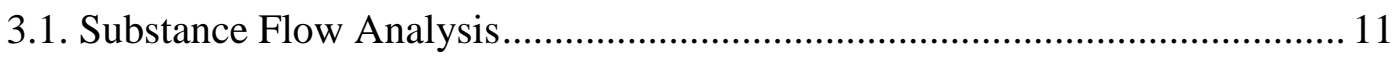

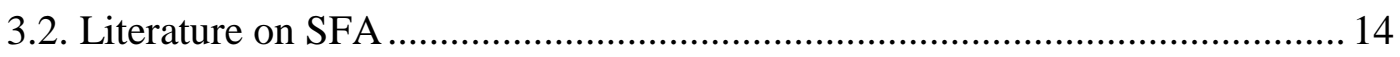

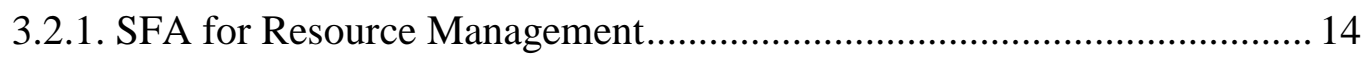

3.2.2. SFA for Environmental Management ................................................... 16

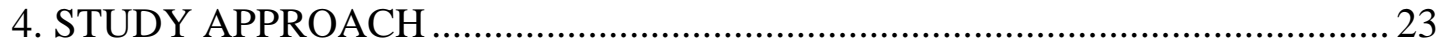

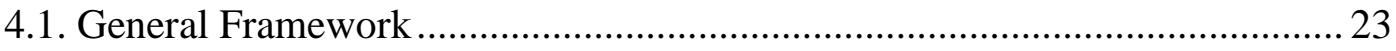

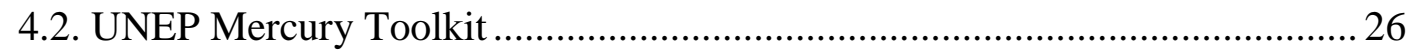

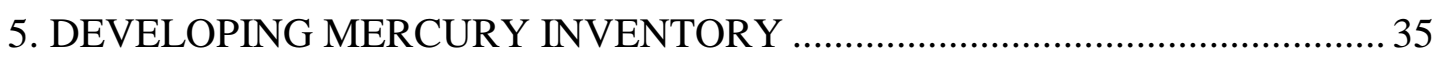

5.1. Mercury Releases from Energy Consumption and Fuel Production............... 36 
5.1.1. Coal Combustion in Large Power Plants ................................................... 37

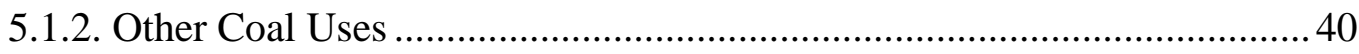

5.1.3. Oil Extraction, Refining and Use ........................................................ 41

5.1.4. Natural Gas Extraction, Processing and Use .......................................... 45

5.1.5. Biomass Fired Power and Heat Production ............................................. 46

5.2. Mercury Releases from Domestic Production of Metals and Raw Materials . 47

5.2.1. Production of Copper from Concentrates ............................................... 49

5.2.2. Gold Extraction by Methods other than Mercury Amalgamation ............ 50

5.2.3. Alumina Production from Bauxite (Aluminum Production) ....................52

5.2.4. Primary Ferrous Metal Production (Pig Iron Production) ........................ 54

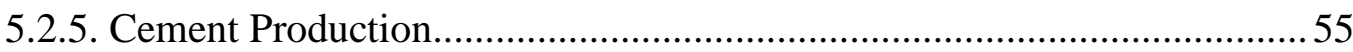

5.3. Intentional Use of Mercury in Industrial Processes and Consumer Products . 56

5.3.1. Production and Consumption of $\mathrm{Hg}$ Thermometers ................................59

5.3.2. Production and Use of Light Sources with Mercury …........................... 63

5.3.3. Production and Use of Batteries with Mercury......................................... 66

5.3.4. Production and Use of Electrical Switches and Relays with Mercury ..... 69

5.3.5. Use of Dental Amalgam Fillings ........................................................ 70

5.3.6. Other Use of Mercury in Products ........................................................... 73

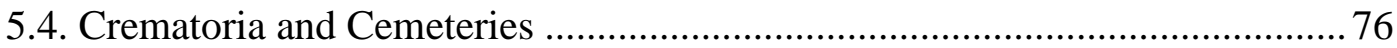

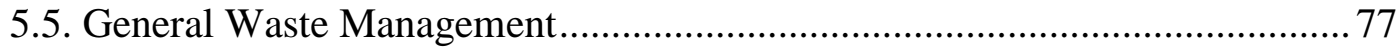

5.5.1. Incineration of Hazardous Waste.......................................................... 78

5.5.2. Incineration and Open Burning of Medical Waste ................................. 79

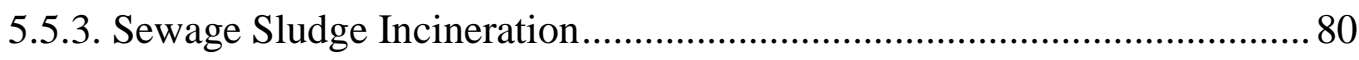

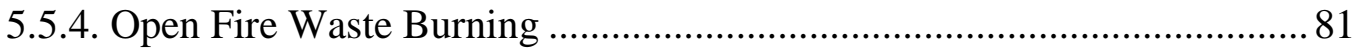

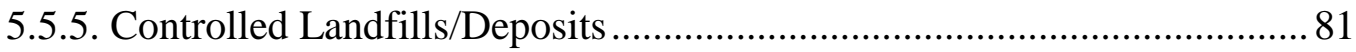

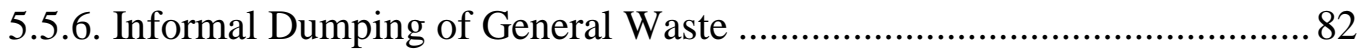

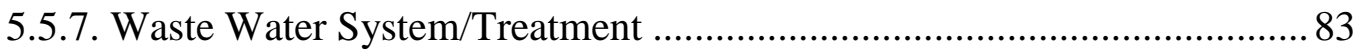

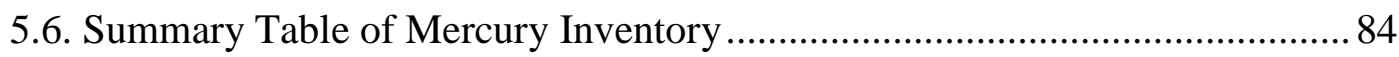

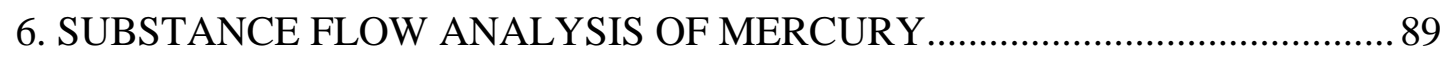

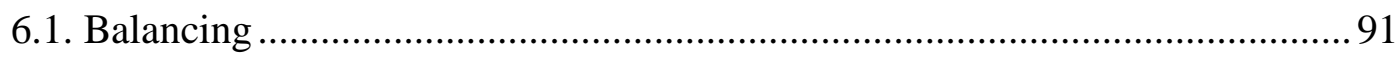

6.1.1. Balancing of "Wastewater Treatment" ................................................. 91

6.1.2. Balancing of "Waste Management"....................................................... 93 
6.2. Mercury Releases to the Environment .95

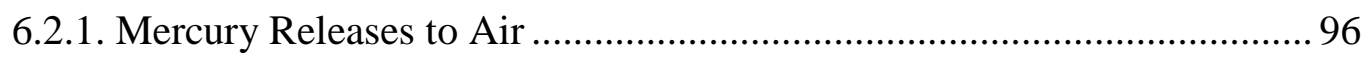

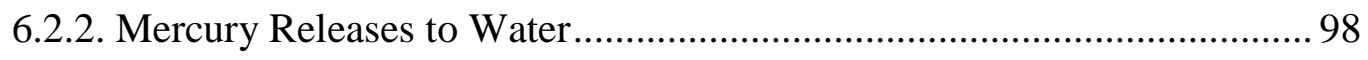

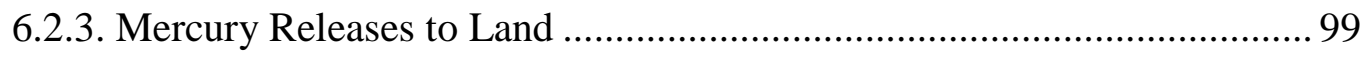

6.2.4. What to do to decrease environmental mercury releases? ..................... 100

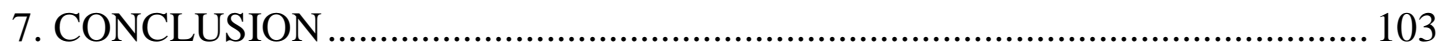

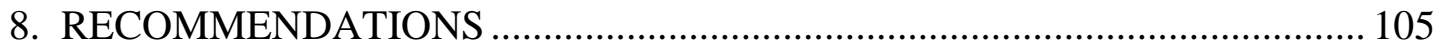

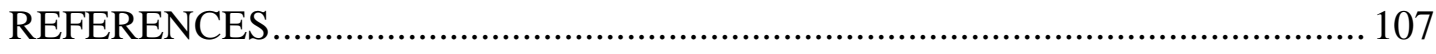
APPENDICES

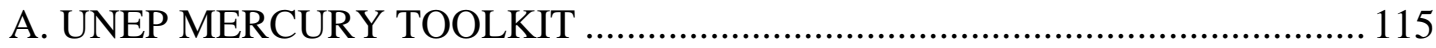

B. INPUT FACTORS AND ACTIVITY RATE DATA …................................... 119 


\section{LIST OF TABLES}

\section{TABLES}

Table 1: Physical properties of mercury (ATSDR, 2014) .......................................

Table 2: Input factors used for the estimation of mercury releases ......................... 28

Table 3: Output distribution factors (UNEP-CB, 2012) …...................................... 31

Table 4: Sub-categories covered under Energy Consumption and Fuel Production

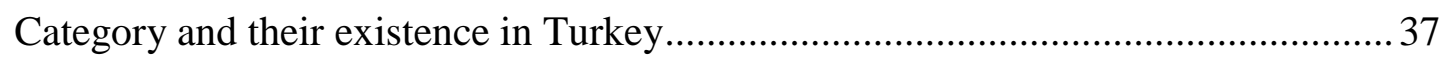

Table 5 : Amounts of coal consumed in Turkey in 2011 (TCE, 2013) ...................... 39

Table 6: Input factor range for mercury in coal used in power plants for energy

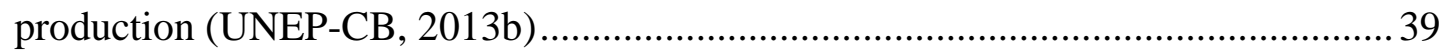

Table 7: Mercury concentrations of Turkish coals (Finkelman, 2004 as cited in

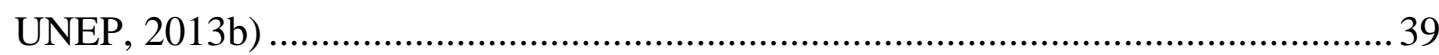

Table 8: Input factor range for mercury in oil (UNEP-CB, 2013b) .......................... 42

Table 9: Input factor range for mercury in natural gas (UNEP-CB, 2013b) .............. 45

Table 10: Input factor range for mercury in biomass used for energy production (UNEP-CB, 2013b) . .46

Table 11: Sub-categories covered under Domestic Production of Metals and Raw Materials and their existence in Turkey 48

Table 12: Input factor range for mercury in concentrates for copper production (UNEP-CB, 2013b) 49

Table 13: Amount of copper concentrate consumed in Turkey between 1999-2005 (SPO, 2006) .50

Table 14: Input factor range for mercury in the gold ore (UNEP-CB, 2013b) .........51

Table 15: Default input factor range for mercury in bauxite (UNEP-CB, 2013b).....53

Table 16: Sub-Categories covered under Intentional Use of Mercury in Industrial Processes and Consumer Products ..........................................................................58

Table 17: Mercury content of industrial thermometers (UNEP-CB, 2013b) ...............60

Table 18: Mercury content of thermometers (UNEP-CB, 2013b) .............................62

Table 19: Input factors for light sources (UNEP-CB, 2013b) ................................... 64 
Table 20: Default mercury content of batteries (UNEP-CB, 2013b)

Table 21: Input factor range for mercury use in switches, contacts and relays (UNEP$\mathrm{CB}, 2013 \mathrm{~b})$

Table 22: Mercury used during the preparation of dental amalgam fillings (UNEP$\mathrm{CB}, 2013 b)$

Table 23: Default mercury output distribution factors for dental amalgam fillings (UNEP-CB, 2013b) 72

Table 24: Mercury input factor range for medical blood pressure gauges (UNEP-CB, 2013b) .73

Table 25: Mercury input factor range for cemeteries (UNEP-CB, 2013b)................ 76

Table 26: Sub-Categories covered under General Waste Management..................... 77

Table 27: Mercury input factor range for medical waste (UNEP-CB, 2013b) .......... 78

Table 28: Output distribution factors for incineration of municipal waste with

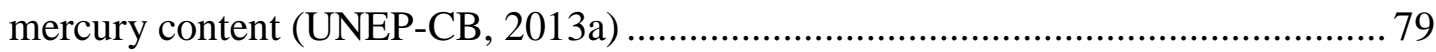

Table 29: Mercury input factor range for municipal waste (UNEP-CB, 2013b)....... 82

Table 30: Mercury input factor range for municipal wastewater (UNEP-CB, 2013b)

Table 31: Mercury Inventory 85

Table 32: Input factor range for mercury in wastewater (UNEP-CB, 2013b).... 92

Table 33 : Output distribution factors for wastewater treatment (UNEP-CB, 2013b)

Table 34: Output distribution factors for landfilling (UNEP-CB, 2013b) 94

Table 35: Input Factors and Activity Rate Data Collected for Turkey 119 


\section{LIST OF FIGURES}

\section{FIGURES}

Figure 1: Schematic description of MFA (Different colors represents different use areas of the substance of concern) (Jamtrot, Seriki, \& Pettersson, 2010) .................. 11 Figure 2: Possible pathways of mercury in the country ..........................................2 24

Figure 3: Bituminous coal consumption in Turkey in 2011 (TCE, 2013) ................. 38

Figure 4: Lignite consumption in Turkey in 2011 (TCE, 2013) ................................ 38

Figure 5: Crude oil distillation process (Littlepage, 2013) ...................................... 43

Figure 6: SFA diagram of mercury in Turkey..................................................... 90

Figure 7: Distribution of mercury to different environmental media in Turkey ........95

Figure 8: Contribution of sources to mercury releases to air in Turkey ....................96

Figure 9: Contribution of energy sources to primary energy supply in Turkey in 2011

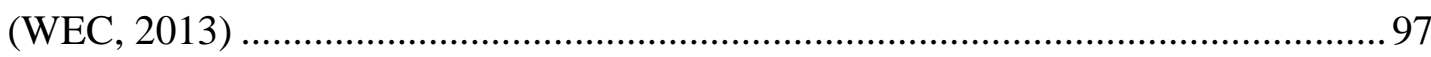

Figure 10: Contribution of sources to mercury releases to water in Turkey .............. 99

Figure 11: Contribution of sources to mercury releases to land in Turkey.............. 100 Figure 12: Screenshot of UNEP Mercury Toolkit Level 1 Step 2 Energy Consumption and Fuel Production ....................................................................... 117 


\author{
ABBREVATIONS \\ UNEP: United Nations Environment Programme \\ SFA: Substance Flow Analysis \\ MFA: Material Flow Analysis \\ EU: European Union \\ WFD: Water Framework Directive \\ EQS: Environmental Quality Standards \\ PBT: Persistent, bioaccumulative, toxic \\ TSI: Turkish Statics Institute
}

TUoCCE: The Union of Chambers and Commodity Exchanges of Turkey WWTP: Wastewater Treatment Plant 


\section{CHAPTER 1}

\section{INTRODUCTION}

\subsection{General Information}

Mercury is a naturally occurring element found in soil, rock and biomass in trace amounts (Sang and Lourie, 1997). However, it can build up in the environment as a result of anthropogenic activities; like intentional use of mercury in products and processes and activities mobilizing naturally existing mercury.

Because of its special properties mercury has been widely used in products and processes. For example, it is preferred to be used in switches, relays, barometers and thermometers because mercury conducts electricity and expands depending on the temperature and pressure changes. In addition, mercury is used in fluorescent lamps because it forms complex molecules that can emit light. Mercury can combine with other metals and form amalgams to be used in different areas like dental amalgam fillings as well as gold mining (Pollution Probe, 2003). The use of mercury in batteries is among the largest uses of mercury in products. Due to its toxic property, mercury is preferred to be used in paints, skin lightening creams, soaps and some cosmetics as preservative. It is used in biocides and pesticides because of the same reason. However, these uses are very limited and controlled.

Production and use of products containing mercury, as well as their disposal cause mercury releases to the environment. Its use in products was peak during the years 1960s, and then it has started to decrease due to the activities regarding to phasing out of mercury. The sharpest decrease was observed in the 1990s (Cain, Disch, Twaroski, Reindl, \& Case, 2007) but still continue to be used. In addition, during processing of mineral resources, production of chemicals, metal and materials 
production, mercury is released to the environment as a result of its use during the process or because of the mercury impurities in the raw material used.

Mercury and its compounds are highly persistent, bio-accumulative and toxic. They can be transported long distances in the air, remains in the water for a long time and accumulates in the food chain. They have negative effects on both environment and human health. In addition to that, exposure to mercury can cause harm on nervous system, brain, kidney, skin and developing fetus (Fridmanis, Torpovs, \& Linde, 2011). Therefore, control of mercury releases to the environment is critical.

Due to its above-mentioned effects on the environment and human health, mercury is considered as a chemical of concern by different organizations and countries all around the world. It is classified among the priority pollutants by many countries (EU countries, USA, Turkey etc.). According to the European Union (EU) Water Framework Directive (WFD, 2000/60/EC), member states should achieve "good status" of surface and ground waters until 2015. To this end, the Directive on Environmental Quality Standards (EQS) (2008/ 105/ EC) defines EQS for 45 priority substances, including mercury, in water, sediment and biota for their control in the aquatic environment. EU Member States should take necessary precautions with the purpose of gradually reducing pollution from priority substances, and phasing out emissions, and ensure the compliance of EQS according to the EQS Directive.

When Turkey's EU Accession period is considered, good management of priority pollutants become important in order to meet with the standards defined under WFD. Therefore for a better implementation of the EQS Directive, knowledge of mercury distribution in the environment is of critical importance. According to Hagreen \& Lourie (2004) when the reduction or use management of a contaminant is intended to be applied, the first action should be the determination of major uses, sources and releases. In order to make wise policy for the management of mercury in Turkey, identification of sources, pathways and releases of mercury to the environment is necessary. 
Substance Flow Analysis (SFA) is a tool used for the assessment of the flows and stocks of a substance or material within a specified space and time. It is based on the mass balance principle and links the sources to pathways and final sinks of a substance (Brunner \& Rechberger, 2004). SFA is widely preferred to be used in the area of environmental management and waste management as tool for policy-making (Brunner, 2012). Accumulation of priority pollutants could be minimized by setting priority actions to protect environment with help of SFA (Pacyna, 2009). SFA has been used by many governments and institutions with the aim of control of priority pollutants including mercury. However, there is not any study regarding to the mercury flows in Turkey. There is lack of information about mercury releases from various industrial activities and industrial products in Turkey; and hence about management options. This study which is the first SFA of mercury in Turkey could be a very useful tool for the development of a preliminary estimate of mercury release to the environment in and subsequently the development of environmental policies aiming to control mercury releases to the environment.

\subsection{Objective and Scope of the Study}

The objective of this study is to identify mercury release sources and quantify mercury flows in the borders of Turkey in order to help policy-makers to better understand their options to reduce mercury releases to different environmental compartments by conducting SFA.

Within the scope of the study, mercury inventory of Turkey is developed as a first step; after identification of all possible mercury release sources in Turkey, mercury flows from each source are quantified with the use of United Nations Environment Programme (UNEP) Mercury Toolkit Level 1 which is a spread-sheet developed by UNEP for SFA of mercury. For the calculation of mercury release estimates, default input and output distribution factors available in the toolkit are used. As the second step, SFA of mercury is conducted for mercury in Turkey by using the quantified mercury flows. For this study, Turkey is chosen as the system and time frame is one year. The study does not fit to a certain year because of the lack of data; however, the 
most recent data belonging to years of 2010, 2011 and 2012 are used. Within the concept of this study, mercury flows between the different environmental compartments are not considered.

In this study, some background information about mercury in given in Chapter 2 and SFA methodology is explained and related literature is summarized in Chapter 3. Then, in Chapter 4, methodology used in this study is explained under the name of study approach. Results of the mercury inventory developed for Turkey are given in Chapter 5 and SFA of mercury in Turkey is presented and discussed in Chapter 6. Finally, summary of the study and some future recommendations are given in Chapter 7 and Chapter 8, respectively. This study is the first to identify sources and quantify flows of mercury releases in Turkey to show the existing situation. 


\section{CHAPTER 2}

\section{MERCURY}

Mercury is a naturally found metal in earth's crust. It is also known as quicksilver, metallic mercury, hydrargyrum and liquid silver. It has some special properties making it very valuable. Elemental mercury is a heavy and odorless liquid having the silver color. It is the only metal existing in liquid form at room temperature. Since it has a very low boiling point, it evaporates easily. Even at room temperature it may volatilize. Its solubility is very low in water and organic solvents. Physical properties of mercury are listed in Table 1. In addition, mercury is among the toxins known as persistent, bioaccumulative and toxics (PBTs). It is highly toxic to both environment and human health, and does not give any sign at hazardous concentrations.

Table 1: Physical properties of mercury (ATSDR, 2014)

\begin{tabular}{|l|l|}
\hline Property & Mercury \\
\hline Description & $\begin{array}{l}\text { Liquid is shiny, silvery-white, and heavy; } \\
\text { vapor is colorless and odorless. }\end{array}$ \\
\hline Molecular weight & $200.59 \mathrm{~g} / \mathrm{mole}$ \\
\hline Boiling point $(760 \mathrm{~mm} \mathrm{Hg})$ & $356.72^{\circ} \mathrm{C}$ \\
\hline Freezing point & $-38.9^{\circ} \mathrm{C}$ \\
\hline Specific gravity & 13.6 at $25^{\circ} \mathrm{C}($ water $=1.00)$ \\
\hline Vapor pressure & $0.002 \mathrm{~mm} \mathrm{Hg}$ at $25^{\circ} \mathrm{C}$ \\
\hline Gas density & $6.9($ air $=1)$ \\
\hline Water solubility & $0.006 \%$ at $25^{\circ} \mathrm{C}$ \\
\hline Flammability & Nonflammable \\
\hline
\end{tabular}


Mercury can be found in different forms; elemental mercury $\left(\mathrm{Hg}^{\circ}\right)$, inorganic mercury salts $\left(\mathrm{Hg}_{2} \mathrm{Cl}_{2}, \mathrm{Hg}^{+}, \mathrm{HgCl}_{2}, \mathrm{Hg}^{2+}\right)$ formed through the combination of mercury with chlorine, sulphur or oxygen and organic mercury (methyl mercury, phenyl mercury) formed by the combination of mercury with carbon (ATSDR, 2011).

Most of the mercury in the environment usually is in the forms of metallic and inorganic mercury. From mining of mercury containing ores, coal combustion, municipal and medical waste burning and cement production, metallic and inorganic mercury enter the atmosphere. Since metallic mercury is liquid at room temperature, it may volatilize easily and can be transported long distances. In the air, it can turn into other forms and further carried to water and soil with rain or snow. In addition, inorganic mercury can enter to water and land from wastewater treatment plants (WWTPs) and incineration of municipal waste (containing products with mercury). In addition, the use of mercury containing fungicides can result in the release of inorganic and organic mercury release to the environment (ATSDR, 1999)

Inorganic mercury can be converted to organic mercury (methyl mercury) by microorganisms (bacteria, phytoplankton and fungi) in the environment. Methyl mercury can enter water and soil and remains there for a long time by attaching to small particles. Especially, it can settles down in the water environment and remains there for a long time (ATSDR, 1999).

\subsection{Effects}

\subsubsection{On Human}

Due to its PBT properties, mercury has some negative effects on human health when exposed. It has toxic effects on nervous, digestive and immune systems, and also on lungs, kidneys, skin and eyes (WHO, 2013). Even if exposure to each form of mercury can be toxic for human health, depending on the route of exposure, health effects on the human body may differ. Major routes of exposure are inhalation, 
skin/eye contact and ingestion. Exposure to mercury can be in two major ways; chronic and acute exposure. Factors determining the health effects of mercury are; mercury compound, dose, age of the person exposed, duration and route of exposure. Fetuses are known to be the most sensitive group to mercury toxicity. Exposure to methyl mercury in mother's womb due to fish consumption can result in the damage of developing brain and nervous system. In addition, people who are regularly exposed to mercury, like populations relying on fishing or workers are under high risk.

Elemental mercury is mostly exposed by the inhalation of mercury vapor. Nearly 70$80 \%$ of mercury vapor inhaled is absorbed by the lungs. Since mercury in liquid and vapor form has no odor, it does not provide a warning at hazardous levels. It accumulates at poorly aerated and low-lying areas because mercury vapor is heavier than air. Children who are exposed to mercury vapor through inhalation get highly affected compared to adults, since they are very sensitive. Another way of exposure is skin/eye contact. Irritating elemental mercury vapor is absorbed by the skin and eyes slowly and causes dermatitis. On the other hand, elemental mercury is considered as nontoxic when ingested because less than $0.1 \%$ of it absorbed (ATSDR, 2014).

Methyl mercury has known to be the most toxic one. It has adverse effects on immune and nervous system, ruins the genetic and enzyme systems, coordination and the senses of touch, taste and sight. It is known that exposure to mercury mostly originates from the consumption of fish contaminated with methyl mercury (WHO, 2013). Problems in cognitive thinking, memory, attention, language, and fine motor and visual spatial skills has been observed in children who were exposed to methyl mercury in their mother's womb through the consumption of fish (USEPA, 2014b).

Toxic effects of mercury on human health had been observed through the history, too. Health effects of mercury were firstly realized in Spain, which is known to be the largest producer of mercury in the world, from the workers working in mercury mines during Roman times (Pollution Probe, 2003). There is mercury related 
accidents in the history. The big mercury poisoning was observed in 1950s in Minimata which is a small town located at the western coast of Japan. Many of the people living in the town were complaining about having some difficulties in their speech and movement. On the other hand, Chisso Company was one of the country's leading companies manufacturing acetaldehyde for the production of plastics since 1907. Later, it was understood that mercury discharged from this plant to Minimata Bay was the cause of mercury poisoning in Minimata (Allchin, n.d.). Fish and selfish containing methyl mercury was the biggest portion of Minimata residents' diet on those times. As a result, an episode was observed in 1956 when many people died or got ill, including children. Because of the accident, today, mercury poisoning is named as "Minimata Disease" (Pollution Probe, 2003).

\subsubsection{On Aquatic Life}

Inorganic mercury can be released to water and soil from rocks containing mercury, industrial activities and waste management. Inorganic mercury is converted methyl mercury by microorganisms. Usually it stays in the sediment and soil, and do not reach to groundwater. However, if mercury enters to the water environment, it settles and remains there for a long time. Methyl mercury is the only form of mercury that prefers to accumulate in fish. As a result, mercury starts to accumulate in the food chain in the form of methyl mercury. When the small fish eats the methyl mercury, it starts to accumulate in its tissues. Larger fish eats the small fish and methyl mercury accumulates in its body in larger amounts. Therefore, organisms which are larger and live longer tend to accumulate more methyl mercury in their bodies (ATSDR, 1999). After that, mercury starts to accumulate in human body through the consumption of sea food. As it is mentioned before, consumption of sea food contaminated with mercury poses a risk on human health, especially on developing fetus. In addition to animals in water ecosystem and people, fish-eating birds and mammals get exposed to mercury. High levels of exposure can cause death, reduced production and growth and abnormal behavior on these animals (USEPA, 2014a). 


\subsection{Major Uses}

Mercury use has a long history. It is known that mercury is among the first metals used by human. According to historical records mercury has been known in many civilizations like Egypt and perhaps in the East since 1500 BCE ("Mercury (Hg)," 2014). In the history, mercury was used for writing and painting of tombs and medical purposes as laxative, healer and antiseptic (Pollution Probe, 2003) . In 18th century, mercury was used during the production of beaver felt hats as a preservative. It was observed that, as the time passes workers go mad as a result of mercury exposure. Its neurological effects understood at those times even its use in hat making made the phrase "mad as hatters" very famous (Gad and Pham, 2014). The character named "The Mad Hatter" in Lewis Carolls" novel "Alice in Wonderland" was mad because of mercury poisoning.

Mercury has a wide range of usage area because of its special properties. It is used mainly used in products and processes. In products like thermometers, manometers, barometers, gauges and switches, mercury is used since it conducts electricity and expands depending on the temperature and pressure changes. Mercury is used in fluorescent lamps because it can combine with other gases in its vapor phase to form complex molecules emitting light and there is no any alternative energy saving lamps to fluorescent lamps. In some type of batteries like mercury oxide (zinc-mercury) batteries and button shape batteries, mercury is used as a positive electrode. In addition, mercury is used in pesticides, paints and cosmetics as preservative due to its toxic effects. Since mercury can form amalgam with other metals, it is preferred to be used in dental amalgam fillings because of its cheaper price and long service life. Moreover, for gold mining mercury amalgamation method is sometimes used.

In addition to the use of mercury in products, mercury is preferred to be used in some processes, too. During the chlor-alkali production with mercury technology, VCM production with mercury-dichloride as catalyst and acetaldehyde production with mercury-sulphate as catalyst, mercury is used. These usage areas were used to be preferred more widely in the past; however, in today's world, alternative 
technologies or applications are preferred to be used with the aim of phasing out mercury. In addition to decreasing use of mercury in processes, its use in products are very limited and controlled with the same purpose. Therefore, it is possible to say that mercury use areas are decreasing but still in application in some parts of the world.

\subsection{Major Sources}

Mercury naturally exists in the earth crust. Breakdown of minerals in soil and rock as a result of wind, water and volcanic activity are the natural sources of mercury releases to the environment. It is known that natural mercury release to the environment is in balance, however, anthropogenic activities can cause additional mercury releases to the environment. The amount of mercury in anywhere existing naturally is very low; however, it may be thousand times higher in polluted areas. It is estimated that one third to two third of total annual mercury releases to the environment results from the human activities (ATSDR, 1999).

Mercury is released to the environment from different anthropogenic sources; either from any combustion process as an impurity in fuels and minerals or from the use of mercury on a life cycle basis. It is possible to group them into two; secondary anthropogenic sources; those where mercury is released from the intentional use of it in processes and products. Primary anthropogenic sources are those where naturally existing mercury is mobilized due to human activities like mining, fossil fuel combustion (Sundseth, Pacyna, Pacyna, \& Panasiuk, 2012). Therefore, in addition to natural mercury release sources, anthropogenic activities like fossil fuel combustion, processing of ores; non-ferrous metals and iron and steel, mining activities, production of some materials; pulp and paper and cement, production of industrial chemicals; chlor alkali, acetaldehyde and VCM, products with mercury; batteries, fluorescent lamps, thermometers etc. and waste management activities; incineration of wastes, WWTPs and landfills can be the sources of mercury releases to the environment. 


\section{CHAPTER 3}

\section{SUBSTANCE FLOW ANALYSIS}

\subsection{Substance Flow Analysis}

Material flow analysis (MFA) is an analytical tool used for the determination of flows and stocks of a material in a specified time and space. It focuses on the flows and stocks of a material in a defined region. Schematic description of MFA is presented in Figure 1.

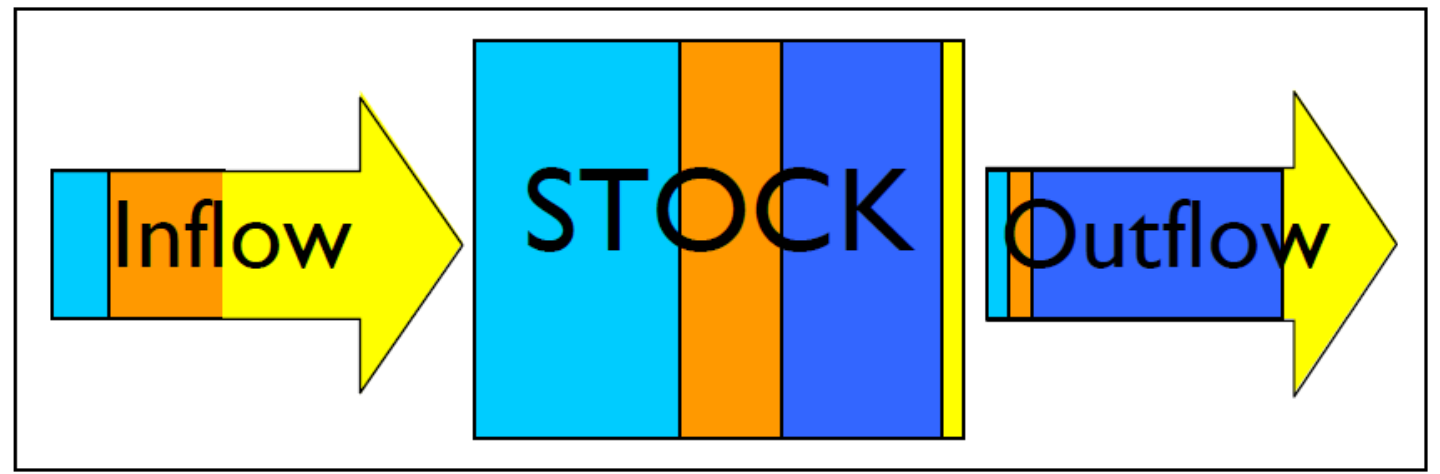

Figure 1: Schematic description of MFA (Different colors represents different use areas of the substance of concern) (Jamtrot, Seriki, \& Pettersson, 2010)

In order to standardize the MFA methodology and get comparable results from studies, common language is necessary. The word "Material" includes both substances and goods. Substance is used for a single type of matter. Good is a substance with positive or negative economic value. When MFA is applied to a substance, then it takes the name of Substance Flow Analysis (SFA). "Process" represents the activities where transformation or storage of materials takes place. Processes could be both anthropogenic and natural. "Stocks" are defined as the 
material reservoirs. Processes are linked to each other via flows or fluxes. Flows entering to a process are called as inputs, while those exiting are outputs (Brunner \& Rechberger, 2004).

SFA is based on basic mass balance principle as shown in Equation (1) (Hansen \& Lassen, 2003). Therefore, it is possible to say that MFA/SFA methodology can be explained by the law of conservation of matter.

Input + Formation $=$ Output + Degradation + Accumulation

With the use of SFA, environmental pollution sources are linked to their final sinks by determining pathways so that sources contributing to environmental releases can be identified. Thus, it can be said that SFA can be used as a tool for decision making (Brunner \& Rechberger, 2004). SFA studies may have different goals; however, understanding the industrial metabolism of a certain substance within a defined system is usually the main goal (Lindqvist \& von Malmborg, 2004). To this end, SFA is widely used with the aim of environmental policy support in different areas like, waste and resource management, environmental management, product design and life cycle assessment (Huang, Vause, Ma, \& Yu, 2012).

Material Flow studies consist of three main steps (Voet, 1996):

1. System definition

2. Quantification of flows and stocks

3. Interpretation of results

In the first step, the system and, if necessary, sub-systems must be defined regarding to space, function, time and materials. Processes, stocks and flows in the system must be specified. "Regional" or "functional" approach can be chosen regarding to "space" and "function. Then, the determination of "time" comes. The unit of material flow studies is usually "mass per time". In SFA studies, generally one-year period is chosen because of the availability of data and policy formulation. Depending on the 
study conducted; shorter or longer time periods can be chosen. After that, material to be studied is chosen. Sometimes, it can be applied to only one substance, compound material or groups of materials depending on the goal of the study (Voet et al., 1995).

The second step is quantification of flows and stocks. This step includes identifying and collecting necessary data. There are three well known ways of modelling the system; bookkeeping, static modelling and dynamic modelling.

Bookkeeping: It is the organization of collected data, therefore it can be hardly considered as a model. However, it presents valuable information for environmental policy. Data includes information about the size of the flows and stocks of a system that can be gathered from trade and production statistics. Monitoring data when applied with mass balance principle helps to have an overview of flows and stocks. This method could be useful for the identification of problem flows, potential future problems and monitoring of changes in the flows over years. It can be also useful for the determination of missing data (Voet et al., 1995).

Static Modelling: In this approach, there are variables describing the relationship between the flows and stocks of a system. Emission factors and distribution factors over the outputs are the examples of these variables. Static modelling approach could be useful for the determination of causes of an environmental pollution by trace backing the flows or predicting the effectiveness of a pollution abatement techniques (Voet et al., 1995).

Dynamic Modelling: In this method, information regarding to time dimension of the variable like half time and retention time are additionally required. Therefore, dynamic modelling could be useful for the scenario analysis (Voet et al., 1995).

After quantification of flows and stocks of a substance, the latest step is the interpretation of results. There are basically, three types of interpretation; evaluation of the robustness of the quantified data, translating the result into policy relevant terms and linking to policy instruments (Voet et al., 1995). 


\subsection{Literature on SFA}

SFA studies are very useful tools for environmental decision making. There are different applications of SFA methodology in the literature; however, they can be grouped into two according to their objective: environmental management and resource conservation. Especially, it is widely used in the area of environmental management and waste management. In the recent studies, SFA is used with the aim of resource management. In the proceeding sections, the literature on the use of SFA for these two purposes is presented separately.

\subsubsection{SFA for Resource Management}

Depletion of nonrenewable sources is more of an issue in today's world. SFA methodology has started to be used as a tool for of resource management regarding to sustainable development. In the area of resource management, SFA can be used to provide early predictions of depletion and accumulation of a substance within a selected system boundary Therefore, it could be considered as a useful tool for the identification of priorities in resource management (Brunner, 2012).

In one of the recent studies, MFA methodology was applied for silver, in Austria, for the year of 2012. Since silver is a non-renewable source, identification of silver flows in the country is considered to be important for its efficient use. Results of the study can be helpful for the development of strategies for resource, waste and environmental management of silver in the country. In the study, major silver flows including import and export were determined through the application of MFA methodology. MFA was conducted for four main categories: production, fabrication and manufacture, use and waste management process. In Austria, the role of export of silver finished products, mainly silver coin production and export is highly important. However, it is found that since there is no silver mining in Austria, the country is highly depended on silver ore import. Assuming increasing demand for the export of silver finished products, the results of the study showed that the country's dependency on silver ore import will increase. Therefore, recycling of silver and 
restarting silver mining in the country are offered to reduce dependency on the import of silver ore. (Gsodam, Lassnig, Kreuzeder, \& Mrotzek, 2014).

In a study conducted by Guo, Zhong, Song, \& Tian (2010), SFA was used to track zinc flows in China in 2006 for studying industrial metabolism of a metal in a region with the aim of showing the existing situation and recycling activities; therefore providing effective resource management. In the study, major zinc flows from ore, product and any secondary source were followed in China's economy for a year period. Inventory was developed and flows were determined by mass balance approach to give idea about the zinc flows in the country and provide guidance to resource conservation. Results of the study showed that, in 2006, China self-provided $87.5 \%$ and $94.9 \%$ of its zinc raw material need for the manufacture and fabrication stages, respectively. However, this value was found to be lower than the average of last years. This was the implication of increasing import of zinc in the country. During the manufacture and fabrication stages, recycling rates were found to be $3.6 \%$ and $9 \%$, respectively. It is possible to say that recovery of zinc in the country was unsatisfactory. In the recent years, production and use of zinc has increased all around the world. Therefore, China, having an important role in the zinc market, must focus on best management of resources and environmental protection.

The use of nickel, which is silvery white metal used in more than 300,000 products, has increased rapidly over the past century. According to today's consumption rates, nickel resources are estimated to be decreased in 50 years' time. Therefore, efficient resource management becomes more important. Comprehensive understanding of the nickel flows in the country can be useful for the development of sustainable resource use policies. Huang, Vause, Ma, Li, \& Yu (2014) developed SFA diagram of nickel in China for the year of 2009 with the aim of helping to evaluate sustainability of nickel resources. SFA was conducted for production, fabrication and manufacturing, usage and waste management of nickel. In study, five different indicators were developed to evaluate sustainability of nickel resources. One of the indicators showed that sustainability of nickel resources in China is worse than elsewhere in the world, while, another indicator showed that it is slightly better than other countries. 
Therefore, this contradiction reveals that indicators may play different roles in the sustainability assessment. In the study, SFA which can provide spatial information about the resources of nickel was conducted. However, application of dynamic SFA of nickel could help to understand temporal changes in China's nickel resources. Developed indicators showed that sustainable nickel resources could be possible by shrinking China's milling and refining capacity and improving technology and waste management capacity. Recycling ratio should be improved by reducing nickel endproducts exported. Finally, the flow chart of nickel developed showed the importance of cradle-to-cradle management method in nickel industry for sustainable resource management.

\subsubsection{SFA for Environmental Management}

SFA methodology can be used for the control of hazardous substances and priority pollutants in the environment. This is done with the determination of their sources and pathways by using the SFA so that better control strategies can be developed. According to Lindqvist \& von Malmborg (2004) since SFA can put a light on the points which require action for the reduction of pollution loads to the environment, it can show a way to policy decision makers to understand the relationships between the activities and environmental pollution before taking action.

SFA is used widely by different institutions and organizations. Danish EPA has been used SFA methodology for more than two decades in order to identify and control sources causing releases of hazardous substances to the environment. In an article by Hansen \& Lassen (2003), Danish Environment Protection Agency (EPA)'s experience with SFA methodology was evaluated. In this article, it is mentioned that more than 35 SFA studies have been conducted in Denmark. In the following, application of SFA studies summarized in the article and their results are given.

The results of the SFA studies together with other studies are used for the development of substance management and risk minimization in Denmark. The first SFA was for the lead to get idea about the cycling of lead in the country in 1986. 
Results of that study formed some part of the official statement by Danish EPA in 1989. Reduction of lead content of gasoline and to increase the recycling of lead batteries recommended in the study, since these sources were found to be major contributors of lead releases to the environment. Later, second SFA of lead was applied in 1994 to observe the changes. According to the results of the study, direct releases from industrial activities were found to be in lesser amounts compared to releases from landfills due to waste. When two SFA studies were compared in the study, it is observed that some of the major sources of lead releases had reduced significantly, especially lead in electronics due to the changes in regulatory process.

According to (Hagreen \& Lourie, 2004), application of two different SFAs can be useful for understanding the changes in the use patterns of a substance as well as monitoring the effects of regulatory framework like in the lead case. This application could be very useful for the control of some hazardous substances for which only specific use areas are regulated. To this end, SFA for cadmium was applied in Denmark two different times. Results of the study showed that nickel cadmium batteries had over taken the pigments and stabilizers in plastics with time and become the major source from 1977 to 1998 . Cadmium content of zinc and fertilizers were found to be decreased during that period as a result of new technologies and stricter regulatory framework. Also, a sharp decrease in the cadmium content of coal was estimated in the study. However, this can be the result of over estimation of cadmium content of coal when first SFA diagram was formed.

Most of the SFAs developed in Denmark focus on the hazardous substances. However, different than others, SFA of aluminum in Denmark was applied with the concern of resource conservation and environmental effects of a material through its life cycle. The aim of the study was to help minimizing aluminum losses in the cycle in order to provide ideal use of the raw material. It was found that major source of the losses is the aluminum metal in municipal solid waste from packaging products. It was also concluded that recycling is not enough but also material reduction is required. 
SFA was also applied to brominated flame retardants, (BFRs) which are in focus due to its properties like toxicity, stability and tendency to accumulate, to assess their consumption and investigate possibilities of substitution alternatives in Denmark. Use of different types of BFRs for same applications was made this study difficult. In the study, use of BFRs in circuit boards, building materials and plastics products and their import and export flows were studied for Denmark. As a result, products which are in use were estimated to be the major sources of releases to air and wastewater. SFA for BFRs provided a understanding when discussing the draft action plan (Hansen \& Lassen, 2003).

SFA methodology has been used for the identification of flows of priority pollutants in different regions with aim of controlling the pollution regarding to their release to the environment. Since mercury is among the priority pollutants, there are different SFA studies conducted for mercury in the literature.

Hazardous substances cause pollution and pose risks in the Baltic Sea Region. With the aim of identification of sources and quantification of inputs of eleven hazardous substances, including mercury, project named "Control of Hazardous Substances in the Baltic sea Region (COHIBA)" was run during the years 2009-2012 in the region. The aim of the project was to analyze the pathways and find cost effective management options for the control of substances of concern. To this end, SFA was used as a tool. According to the findings of the study, mercury releases related to energy production and industrial production such as cement and zinc production were found to dominate others. Poland was found to be the largest contributor in the region because of its large industry. Mercury releases to different environmental compartments from largest to smallest were found as; air, water and land respectively (Andersson et al., 2012).

Within the scope of the EU Commission funded project "Source Control of Priority Substances in Europe" (SOCOPSE), SFA methodology was adopted for some selected priority substances including mercury, to determine major sources and quantify the releases to the environment in Europe. Project aimed to assess sources 
and pathways of Priority Pollutants for aquatic environment. Within the content of the project, preliminary versions of SFA of priority pollutants were developed on a yearly basis for whole Europe. According to the findings of the study, atmospheric deposition was found to be an important source for mercury in the aquatic environment; especially for heavy metals and PAHs. With the findings of the project, SFA methodology has proven to be a useful tool for the identification of sources, fluxes and end points of a substance (Pacyna, 2009).

According to Sundseth, Pacyna, Pacyna, \& Panasiuk (2012), knowledge of flows of priority substances in a society is important to predict the fate as well as minimize the future environmental burdens. Identification of sources, flows and environmental endpoints of a contaminant is useful for the implementation of many directives, especially WFD (2000/60/EC). Therefore, they conducted SFA of mercury in the EU with the aim of determining existing situation and future trends affecting water quality in Europe. This study includes the updated results from the SFA on mercury from the EU SOCOPSE project mentioned above. According to the findings of the project conducted, anthropogenic sources mobilizing the naturally found mercury are becoming increasingly important. By this project, importance of development of control strategies for industrial sources, wastes and residues from combustion processes were emphasized. Power plants using water for cooling circuit systems and runoff from municipal waste treatment systems were found to be responsible for the majority of mercury discharges to waters in the EU countries. Coal combustion associated with the energy and heat production has appeared as the major source of mercury releases to the atmosphere, while mercury flows in the soil were found to be due to the waste treatment and disposal of ash and fly ash activities (Sundseth et al., 2012).

Since products containing mercury release mercury through their lifecycles, SFA could be applied for the follow of mercury in products. In a study conducted by Cain et al. (2007) in United States, SFA was used to estimate environmental mercury releases from the use of mercury containing products in order to help policy makers to understand the options to reduce releases. In the study, releases from mercury 
containing products; fluorescent lamps, dental amalgam, switches and relays and some control devices were estimated on a life cycle basis; production, distribution, use and disposal. Moreover, analyses were applied for two major sources of mercury releases in United States in 1990: batteries and paints. Results of the study showed that mercury releases from products has decreased dramatically from 1990 to 2005; however, they are still important sources of the releases. Application of SFA methodology helped to understand where mercury releases are originated and informed about the contribution of iron and steel recycling to atmospheric mercury releases. Switches, relays, dental amalgam and measurement and control devices were found to be major contributors of the releases to land in United States in 2005. In the study, it was observed that dental amalgam is the major source of mercury releases to the water.

In another study, Asari et al. (2008) used SFA for one of the mercury-containing products, fluorescent lamps, to quantify mercury flows from production to disposal and assess current management strategies. Nearly 5 tons of mercury flows originate from fluorescent lamps in Japan and the amount is increasing because of the rapid increasing in the use of Liquid Crystal Displays (LCD) containing mercury lamps. It was found that most of the mercury used is disposed while very small amounts are recovered. In the study, SFA is used for the evaluation of different recycling scenarios; present, improved and complete recycling scenario Results of the study showed that recycling of fluorescent lamps should be increased with public participation since fluorescent lamps are among the hazardous household wastes.

SFA methodology could be very useful in the area of environmental policy assessment and development. In one of the studies in which SFA is used, different emission control strategies for cadmium and mercury were evaluated with the help of SFA in order to protect inland surface and groundwater regarding to EU Water Framework Directive (Revitt, Lundy, Eriksson, \& Viavattene, 2013). In the study, two different semi-hypothetical case cities were developed with data from literature and expert judgment. It was found that current EU Legislation is available for reducing cadmium and mercury emissions only between $11 \%$ and $20 \%$. Application 
of voluntary reduction processes was found to be useful for the reduction of emissions from cadmium. The most effective ways of protecting water environment were found to existence of storm water management practices for one city ( $59 \% \mathrm{Hg}$ reduction; 39\% Cd reduction), and advanced water treatment applications for the other city (63\% $\mathrm{Hg}$ reduction; $43 \% \mathrm{Cd}$ reduction).

In one of the studies, the use of SFA methodology for environmental policy decision making was discussed (Reisinger et al., 2009). In the study, for the use of SFA the system was chosen as Austria and time frame as 2005 and substances of concern were lead, cadmium and mercury. After collecting required data, flow diagrams were drawn for the substances. In the study, two major advantages of SFA were highlighted: since SFA is based on law of conservation of matter, balancing inputs and outputs helps to find missing data. Secondly, as cited in Reisinger et al.'s study (2009), because SFA provides "whole picture and full transparency", it is useful for the assessment of different environmental policy strategies. SFA flow charts showed the points requiring further action regarding to resource, waste and environmental policy. 


\section{CHAPTER 4}

\section{STUDY APPROACH}

\subsection{General Framework}

In this study, the goal is to quantify mercury flows to determine major sources of mercury in the environment so that policy decision makers can focus on major contributing sources. For doing this, the system is considered as the whole Turkey and possible exposure pathways for mercury are determined. The pathways considered are of two groups (Figure 2); mercury flows in imports/exports, production, processes, consumption, discharges and removal (including degradation, landfill, and incineration by built facilities); and flows in environment media (Huang, Ma, \& Yu, 2014). In the study, first group of pathway is also divided in two groups depending on the sources of mercury; mercury from import/exports and mercury naturally found in the lithosphere.

Mercury enters to the defined system through importing and leaves through exporting as presented in Figure 2. Since there is no mercury production in the borders of Turkey, import of mercury in the products could be considered as the major source of mercury intentionally used in products. It is the only way of mercury supply for Turkey. As it is shown in the Figure 2, imported mercury in products can go under further production processes. Then it is sold on the market and consumed. Products with mercury cause mercury releases to the environment during their life cycles; both production and consumption. These can be direct releases to the air as a result of breakage of products, mercury in municipal or hazardous solid waste and mercury in wastewater due to use of products with mercury. Wastewater is sent to WWTPs in order to be treated; however, most of the time, mercury is discharged to the surface waters from WWTPs in the treated effluents. 
On the other hand, solid waste could be handled in landfills or incinerated. From both solid waste management methods, releases to the environment may occur depending on the conditions, but still in less amounts compared to wild dumping of solid waste. Since sewage sludge also includes some amounts of mercury, land application of the sludge could result in the mercury releases to the land. In this study, during the estimation of mercury releases from the products with intentionally used mercury, import and export amounts are taken into consideration.

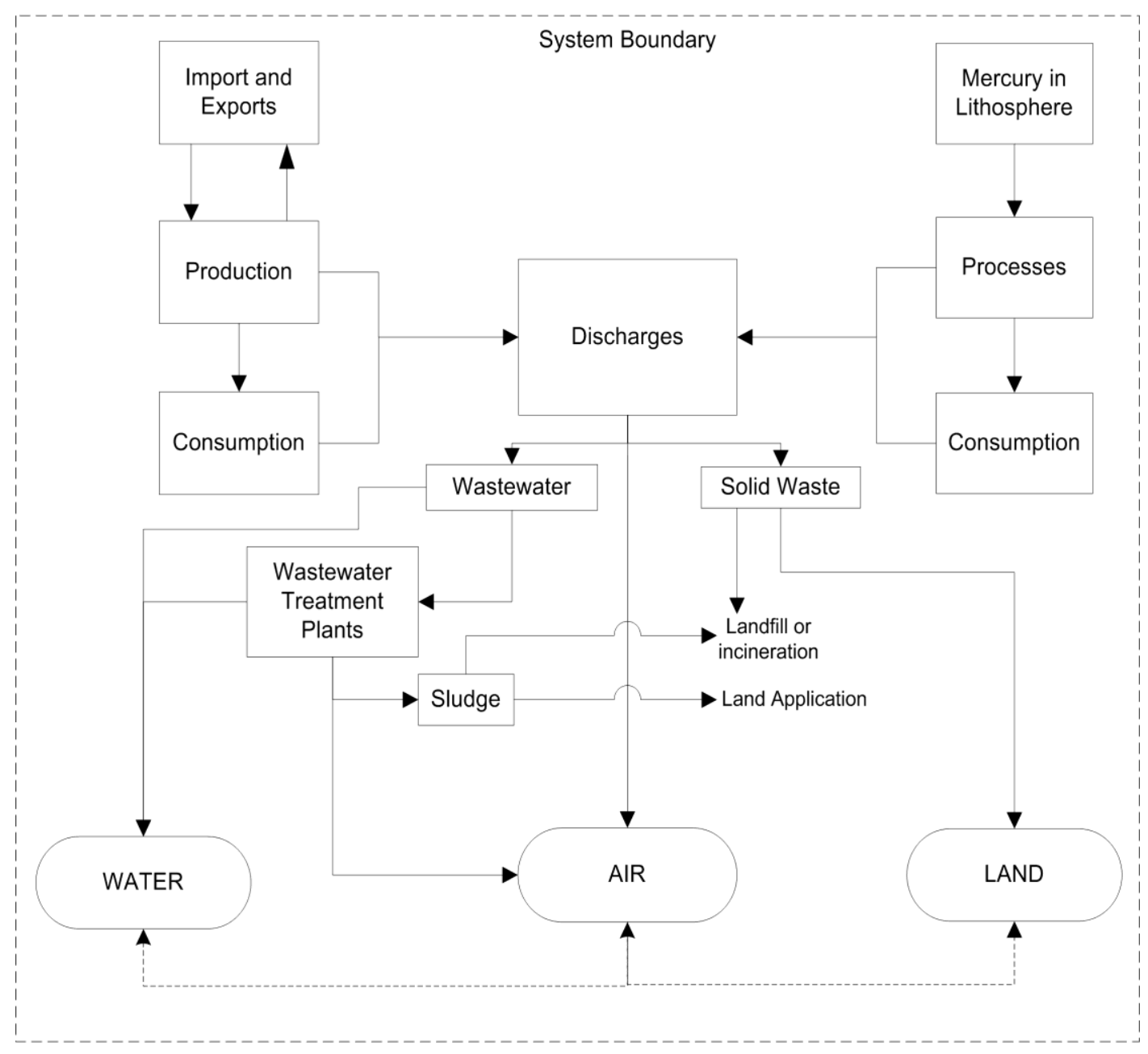

Figure 2: Possible pathways of mercury in the country

Since mercury is naturally found in the environment, mercury in the lithosphere can be another source of mercury pathways shown in Figure 2 because of the anthropogenic activities mobilizing mercury unintentionally. Activities like fossil 
fuel combustion for electricity and heat production and mining of minerals mobilize mercury impurities existing in the fossil fuel and minerals. Therefore, any processes in which fossil fuel combustion take place is considered as the source of mercury release to the environment. Discharges from this pathway are the same as with the pathway of mercury from import/export.

Flows between different environmental media (air, water and land) are not studied within the concept of this study. The time frame is chosen as one year; however, the most recent available data used for the estimation of mercury flows due to the lack of data. Therefore, results of this study can be mostly considered as a representative of average of the years of 2010, 2011 and 2012.

Quantification of yearly flows of mercury for each pathway is done based on the best available estimates. As the second step, identification and quantification of flows are done by using a ready-made toolkit "Mercury Toolkit Level 1" which is developed by UNEP (explained in Section 4.2).

After quantification of mercury flows with the help of UNEP Mercury Toolkit, one year static SFA of mercury in Turkey is formed by linking quantified environmental releases to their sources and presented as a diagram. Input values which are the mercury imported or produced are balanced with the output values which are the environmental releases to different environmental compartments.

During the quantification of flows, the stock of mercury is assumed to be constant and therefore is not included in calculations. With the help of the SFA diagram formed pathways of mercury flows in Turkey is determined and major sources contributing to these releases are identified to help policy decision makers when implementing regulatory framework. 


\subsection{UNEP Mercury Toolkit}

Identification of mercury releases to the environment is of critical importance in order to control and minimize them. To this end, UNEP has developed an instrument named "Mercury Toolkit" with the aim of helping countries to develop their national mercury inventories so that mercury releases can be identified and addressed all over the world. Different datasets from different countries can help to understand general picture about the mercury releases all around the world. Some additional information about the toolkit is provided in Appendix A.

There are two levels of Mercury Toolkit: Level 1 and Level 2. Mercury Toolkit Level 1, which is the further simplified version of Level 2, uses some default input and output factors for the quantification of mercury release estimates; however, Level 2 is more adaptable to the different situations where specific input and output distribution factors are available for the sources. In this study, UNEP Mercury Toolkit Level 1 is used for the quantification of mercury flows, which are required for the formation of SFA, since Level 1 is recommended for the developing countries which have not developed their preliminary inventories yet and usually lack of required data to develop their own national mercury inventory. After the formation of preliminary inventory with Level 1 , more specific and complex inventory can be developed with Level 2. The basic aim of the both toolkits is to estimate average annual mercury releases from sources (UNEP-CB, 2013b).

Mercury Toolkit is MS Excel based program and consisted of different sheets in which major activities where mercury releases may occur are studied. These major sources are energy consumption and fuel production, domestic production of metals and raw materials, domestic production and processing with intentional mercury use, waste treatment and recycling, general consumption of mercury in products and crematoria and cemeteries. Under each major source category, subcategories are defined regarding to major activity. Through the development of mercury inventory, as a first step, main sources presenting in Turkey are identified and further subcategorized regarding to main sources given above. 
As a next step, quantitative inventory is developed. With that purpose, toolkit defines default input and output distribution factors for each source based on literature and field data. Input factor is defined as mercury concentration in the feed material. Output distributions factors are used to determine how releases are distributed to different environmental compartments. Since Mercury Toolkit Level 1 includes default input and output distribution factors, only activity rate data, which is the amount of mercury containing material fed into the system, must be supplied to the toolkit for the quantification of mercury release estimates (UNEP-CB, 2013a).

\section{Activity Rate Data Collection}

Activity rate data could be in the form of tons/year, item consumed/year, item produced/year, etc. Activity rate data is collected for 45 different sources/activities. Required activity rate data which is specific to Turkey are mostly gathered from the following sources:

- Turkish sector reports like Turkish Coal Sector Report prepared by Turkish Coal Enterprises, Turkish Cement Industry Report prepared by Turkish Ministry of Science, Industry and Technology, etc.

- Industrial Development Plans prepared by Turkish State Planning Organization

- Turkish Statistics Institute (TSI) Databases: Foreign Trade Statistics, Demography Statistics and Environmental Statistics Databases

- The Union of Chambers and Commodity Exchanges of Turkey (TUoCCE) Industrial Database

- Personal Communication

After required activity rate data is collected, for the calculation of mercury input from a defined source, activity rate data is multiplied with default mercury input factor given in the toolkit by UNEP. Generalized formula for mercury input calculation from whole sources are given in Equation (2), 


$$
M I=A R D \times I F
$$

Where MI is mercury input to the environment from the activity/source, ARD is activity rate data for the activity/source, and IF is mercury input factor for the activity/source.

Input factors used in this study are given in Table 2. In the toolkit guideline, input factor ranges are defined for each source based on the literature and field data. However; in the Mercury Toolkit Level 1, medium values of the range are taken as default, and calculation of estimates are done with the use of those numbers. Only for the estimation of mercury releases from gold extraction, input value specific to Turkey is used in this study in order to prevent overestimation. For all other sources, default input factors defined by UNEP are used because of the lack of data in Turkey. However; during the formation of SFA diagram, input factors for controlled landfills and WWTPs are estimated by going back through the diagram formed with the aim of balancing (Section 6.1). However, it should be noted that these input factors are preliminary and future revisions are required.

Table 2: Input factors used for the estimation of mercury releases

\begin{tabular}{|l|c|c|}
\hline Source & Input Factor & Reference \\
\hline \multicolumn{2}{|l|}{ Energy Consumption and Fuel Production } \\
\hline Coal combustion in large power plants & $0.15 \mathrm{~g} / \mathrm{t}$ & (UNEP-CB, 2012) \\
\hline Other coal uses & $0.13 \mathrm{~g} / \mathrm{t}$ & (UNEP-CB, 2012) \\
\hline Oil extraction & $3.4 \mathrm{mg} / \mathrm{t}$ & $(\mathrm{UNEP}-\mathrm{CB}, 2012)$ \\
\hline Oil refining & $3.4 \mathrm{mg} / \mathrm{t}$ & $(\mathrm{UNEP}-\mathrm{CB}, 2012)$ \\
\hline $\begin{array}{l}\text { Combustion/use of petroleum coke and } \\
\text { heavy oil }\end{array}$ & $55 \mathrm{mg} / \mathrm{t}$ & (UNEP-CB, 2012) \\
\hline $\begin{array}{l}\text { Combustion/use of diesel, gasoil, } \\
\text { petroleum, kerosene }\end{array}$ & $5.5 \mathrm{mg} / \mathrm{t}$ & (UNEP-CB, 2012) \\
\hline Extraction and processing of natural gas & $100 \mu \mathrm{g} / \mathrm{Nm}^{3}$ & (UNEP-CB, 2012) \\
\hline Use of pipeline gas (consumer quality) & $0.2 \mu \mathrm{g} / \mathrm{Nm}{ }^{3}$ & (UNEP-CB, 2012) \\
\hline Biomass fired power and heat production & $0.03 \mathrm{~g} / \mathrm{t}$ & (UNEP-CB, 2012) \\
\hline Domestic Production of Metals and Raw Materials \\
\hline Production of copper from concentrates & $30 \mathrm{~g} / \mathrm{t}$ & (UNEP-CB, 2012) \\
\hline
\end{tabular}


Table 2 (continued)

\begin{tabular}{|c|c|c|}
\hline Source & Input Factor & Reference \\
\hline $\begin{array}{l}\text { Gold extraction by methods other than } \\
\text { mercury amalgamation }\end{array}$ & $1 \mathrm{~g} / \mathrm{t}$ & $\begin{array}{c}\text { (Canadian } \\
\text { Environmental and } \\
\text { Metallurgical Inc., 2006) }\end{array}$ \\
\hline Alumina production from bauxite & $0.5 \mathrm{~g} / \mathrm{t}$ & (UNEP-CB, 2012) \\
\hline Primary ferrous metal production & $0.05 \mathrm{~g} / \mathrm{t}$ & (UNEP-CB, 2012) \\
\hline Cement production & $0.13 \mathrm{~g} / \mathrm{t}$ & (UNEP-CB, 2012) \\
\hline \multicolumn{3}{|c|}{ Intentional Use of Mercury in Industrial Processes and Consumer Products } \\
\hline Production of $\mathrm{Hg}$ Thermometers & $10 \mathrm{~g} /$ item & (UNEP-CB, 2012) \\
\hline $\begin{array}{l}\text { Use of Ambient air temperature } \mathrm{Hg} \\
\text { thermometer }\end{array}$ & $3.5 \mathrm{~g} /$ item & (UNEP-CB, 2012) \\
\hline Use of Industrial $\mathrm{Hg}$ thermometers & $10 \mathrm{~g} /$ item & (UNEP-CB, 2012) \\
\hline Use of Other glass $\mathrm{Hg}$ thermometers & $20.5 \mathrm{~g} /$ item & (UNEP-CB, 2012) \\
\hline $\begin{array}{l}\text { Production of Discharge Lamps with } \\
\text { Mercury }\end{array}$ & $30 \mathrm{mg} /$ item & (UNEP-CB, 2012) \\
\hline Production of UV Lamps with Mercury & $25 \mathrm{mg} /$ item & (UNEP-CB, 2012) \\
\hline Use of High pressure sodium lamp & $30 \mathrm{mg} /$ item & (UNEP-CB, 2012) \\
\hline Use of Metal halide lamp & $25 \mathrm{mg} /$ item & (UNEP-CB, 2012) \\
\hline Use of UV light for tanning & $25 \mathrm{mg} /$ item & (UNEP-CB, 2012) \\
\hline Use of Florescent tubes (double end) & $25 \mathrm{mg} /$ item & (UNEP-CB, 2012) \\
\hline $\begin{array}{l}\text { Use of Compact florescent lamp (CFL } \\
\text { single end) }\end{array}$ & $10 \mathrm{mg} /$ item & (UNEP-CB, 2012) \\
\hline Use of Mercury oxide batteries & $320 \mathrm{~kg} / \mathrm{t}$ & (UNEP-CB, 2012) \\
\hline Use of Zinc-air button cells batteries & $12 \mathrm{~kg} / \mathrm{t}$ & (UNEP-CB, 2012) \\
\hline Use of Alkaline button cells batteries & $5 \mathrm{~kg} / \mathrm{t}$ & (UNEP-CB, 2012) \\
\hline Use of Silver oxide button cells batteries & $4 \mathrm{~kg} / \mathrm{t}$ & (UNEP-CB, 2012) \\
\hline $\begin{array}{l}\text { Production and Use of Electrical } \\
\text { Switches and Relays with Mercury }\end{array}$ & $\begin{array}{c}0.07 \\
\text { g/person.year }\end{array}$ & (UNEP-CB, 2012) \\
\hline Use of Dental Amalgam Fillings & $\begin{array}{c}0.2 \\
\text { g/person.year }\end{array}$ & (UNEP-CB, 2012) \\
\hline Use of medical blood pressure gauges & $80 \mathrm{~g} / \mathrm{item}$ & (UNEP-CB, 2012) \\
\hline Use of manometers and gauges & $\begin{array}{c}0.005 \\
\text { g/person }\end{array}$ & (UNEP-CB, 2012) \\
\hline Use of mercury in laboratories & $0.01 \mathrm{~g} /$ person & (UNEP-CB, 2012) \\
\hline \multicolumn{3}{|l|}{ Cemeteries } \\
\hline Cemeteries & $2.5 \mathrm{~g} /$ corpse & (UNEP-CB, 2012) \\
\hline
\end{tabular}


Table 2 (continued)

\begin{tabular}{|c|c|c|}
\hline Source & Input Factor & Reference \\
\hline \multicolumn{3}{|l|}{ General Waste } \\
\hline Incineration of Hazardous Waste & $24 \mathrm{~g} / \mathrm{t}$ & (UNEP-CB, 2012) \\
\hline $\begin{array}{l}\text { Incineration and Open Burning of } \\
\text { Medical Waste }\end{array}$ & $24 \mathrm{~g} / \mathrm{t}$ & (UNEP-CB, 2012) \\
\hline Sewage Sludge Incineration & $2 \mathrm{~g} / \mathrm{t}$ & (UNEP-CB, 2012) \\
\hline Open Fire Waste Burning & $5 \mathrm{~g} / \mathrm{t}$ & (UNEP-CB, 2012) \\
\hline Controlled Landfills/Deposits & $0.48 \mathrm{~g} / \mathrm{t}$ & Present Study \\
\hline Informal Dumping of General Waste & $5 \mathrm{~g} / \mathrm{t}$ & (UNEP-CB, 2012) \\
\hline Waste Water System/Treatment & $0.63 \mathrm{mg} / \mathrm{m} 3$ & Present Study \\
\hline
\end{tabular}

Toolkit is based on mass balance principle; all mercury input to the system must come out as environmental releases or remain in product. Therefore, after determination of mercury input from an activity, mercury releases to different environmental compartments are calculated by multiplying calculated mercury input with default output distribution factors given in the toolkit by UNEP as shown in Equation (3);

$$
M O=M I x O F
$$

Where MO is amount of mercury output from the activity/source to a specific compartment, MI is estimated mercury input from the activity/source, and OF is mercury output factor for the activity/source for a specific compartment.

Toolkit defines output distribution factors for five main mercury release pathways for each source, if applicable, as follows (UNEP-CB, 2013b);

- Air: releases to atmosphere

- Water: releases to aquatic environment

- Land: releases to terrestrial environment

- By-products: by- products containing mercury and sent back to the market

- General Waste: municipal waste 
- Sector Specific Waste Treatment: waste from industry and products, collected and handled separately.

While developing mercury inventory for Turkey, releases to given pathways are determined for each source. Since specific data about output distribution factors for each source in Turkey is not available, default output distribution factors defined by UNEP as shown in Table 3, which are determined based on collected field data from different facilities, are used for the estimation of mercury releases from each source.

It should be noted that while using the toolkit, required consumption data is calculated as shown in Equation (4) (UNEP-CB, 2013b);

Consumption $=$ Production + Import - Export $($ annually $)$

Table 3: Output distribution factors (UNEP-CB, 2012)

\begin{tabular}{|c|c|c|c|c|c|c|}
\hline \multirow[b]{2}{*}{ Source } & \multicolumn{6}{|c|}{ Output Distribution Factors } \\
\hline & Air & Water & Land & $\begin{array}{c}\text { By- } \\
\text { products } \\
\text { and } \\
\text { impurities }\end{array}$ & $\begin{array}{l}\text { General } \\
\text { waste }\end{array}$ & $\begin{array}{c}\text { Sector } \\
\text { specific } \\
\text { waste } \\
\text { treatment } \\
\text { /disposal }\end{array}$ \\
\hline \multicolumn{7}{|c|}{ Energy Consumption and Fuel Production } \\
\hline $\begin{array}{l}\text { Coal Combustion in } \\
\text { Large Power Plants }\end{array}$ & 0.88 & - & - & - & - & 0.12 \\
\hline Other Coal Uses & 1 & - & - & - & - & - \\
\hline Oil Extraction & - & 0.2 & - & - & - & - \\
\hline Oil Refining & 0.25 & 0.01 & - & - & - & 0.15 \\
\hline $\begin{array}{l}\text { Combustion/use of } \\
\text { Petroleum Coke and } \\
\text { Heavy Oil }\end{array}$ & 1 & - & - & - & - & - \\
\hline $\begin{array}{l}\text { Combustion/use of } \\
\text { Diesel, Gasoil, } \\
\text { Petroleum, Kerosene }\end{array}$ & 1 & - & - & - & - & - \\
\hline
\end{tabular}


Table 3 (continued)

\begin{tabular}{|c|c|c|c|c|c|c|}
\hline \multirow[b]{2}{*}{ Source } & \multicolumn{6}{|c|}{ Output Distribution Factors } \\
\hline & Air & Water & Land & $\begin{array}{l}\text { By- } \\
\text { products } \\
\text { and } \\
\text { impurities }\end{array}$ & $\begin{array}{l}\text { General } \\
\text { waste }\end{array}$ & $\begin{array}{c}\text { Sector } \\
\text { specific } \\
\text { Waste } \\
\text { treatment } \\
\text { /disposal }\end{array}$ \\
\hline $\begin{array}{l}\text { Extraction and } \\
\text { Processing of Natural } \\
\text { Gas }\end{array}$ & 0.15 & 0.2 & - & 0.3 & - & 0.35 \\
\hline $\begin{array}{l}\text { Use of Pipeline Gas } \\
\text { (consumer quality) }\end{array}$ & 1 & - & - & - & - & - \\
\hline $\begin{array}{l}\text { Biomass Fired Power } \\
\text { and Heat Production }\end{array}$ & 1 & - & - & - & - & - \\
\hline \multicolumn{7}{|c|}{ Domestic Production of Metals and Raw Materials } \\
\hline $\begin{array}{l}\text { Production of Copper } \\
\text { from Concentrates }\end{array}$ & 0.1 & 0.02 & - & 0.42 & - & 0.46 \\
\hline $\begin{array}{l}\text { Gold Extraction by } \\
\text { Methods Other than } \\
\text { Mercury Amalgamation }\end{array}$ & 0.04 & 0.02 & 0.9 & 0.04 & - & - \\
\hline $\begin{array}{l}\text { Alumina production } \\
\text { from bauxite }\end{array}$ & 0.15 & 0.1 & - & - & 0.65 & 0.1 \\
\hline $\begin{array}{l}\text { Primary ferrous metal } \\
\text { production }\end{array}$ & 0.95 & - & - & - & - & 0.05 \\
\hline Cement production & 0.75 & - & - & 0.25 & - & - \\
\hline \multicolumn{7}{|c|}{ Intentional Use of Mercury in Industrial Processes and Consumer Products } \\
\hline $\begin{array}{l}\text { Production of } \mathrm{Hg} \\
\text { Thermometers }\end{array}$ & 0.01 & 0.005 & 0.1 & - & 0.1 & 0.01 \\
\hline $\begin{array}{l}\text { Consumption of } \mathrm{Hg} \\
\text { Thermometers }\end{array}$ & 0.1 & 0.3 & - & - & 0.6 & - \\
\hline $\begin{array}{l}\text { Production of Light } \\
\text { Sources with Mercury }\end{array}$ & 0.01 & 0.005 & 0.1 & - & 0.1 & 0.01 \\
\hline $\begin{array}{l}\text { Use of Light Sources } \\
\text { with Mercury }\end{array}$ & 0.05 & - & - & - & 0.95 & - \\
\hline $\begin{array}{l}\text { Production and Use of } \\
\text { Batteries with Mercury }\end{array}$ & - & - & - & - & 1 & - \\
\hline $\begin{array}{l}\text { Production and Use of } \\
\text { Electrical Switches and } \\
\text { Relays with Mercury }\end{array}$ & 0.1 & - & 0.1 & - & 0.8 & - \\
\hline
\end{tabular}


Table 3 (continued)

\begin{tabular}{|c|c|c|c|c|c|c|}
\hline \multirow[b]{2}{*}{ Source } & \multicolumn{6}{|c|}{ Output Distribution Factors } \\
\hline & Air & Water & Land & $\begin{array}{c}\text { By- } \\
\text { products } \\
\text { and } \\
\text { impurities }\end{array}$ & $\begin{array}{l}\text { General } \\
\text { waste }\end{array}$ & $\begin{array}{c}\text { Sector } \\
\text { specific } \\
\text { waste } \\
\text { treatment } \\
\text { /disposal }\end{array}$ \\
\hline \multicolumn{7}{|c|}{ Use of Dental Amalgam Fillings } \\
\hline $\begin{array}{l}\text { Prep. of fillings at } \\
\text { dentist clinics }\end{array}$ & 0.02 & 0.14 & - & 0.6 & 0.12 & 0.12 \\
\hline $\begin{array}{l}\text { Use- from fillings in } \\
\text { the mouth }\end{array}$ & - & 0.02 & - & - & - & - \\
\hline Disposal & - & 0.3 & - & 0.06 & 0.12 & 0.12 \\
\hline $\begin{array}{l}\text { Use of medical blood } \\
\text { pressure gauges }\end{array}$ & 0.1 & 0.3 & - & - & 0.6 & - \\
\hline $\begin{array}{l}\text { Use of manometers } \\
\text { and gauges }\end{array}$ & 0.1 & 0.3 & - & - & 0.6 & - \\
\hline $\begin{array}{l}\text { Use of mercury in } \\
\text { laboratories }\end{array}$ & - & 0.33 & - & - & 0.33 & 0.33 \\
\hline \multicolumn{7}{|c|}{ Crematoria and Cemeteries } \\
\hline Cemeteries & - & - & 1 & - & - & - \\
\hline \multicolumn{7}{|l|}{ General Waste } \\
\hline $\begin{array}{l}\text { Incineration of } \\
\text { Hazardous Waste }\end{array}$ & 0.9 & - & - & - & - & 0.1 \\
\hline $\begin{array}{l}\text { Incineration and Open } \\
\text { Burning of Medical } \\
\text { Waste }\end{array}$ & 0.9 & - & - & - & - & 0.1 \\
\hline $\begin{array}{l}\text { Sewage Sludge } \\
\text { Incineration }\end{array}$ & 0.9 & - & - & - & - & 0.1 \\
\hline $\begin{array}{l}\text { Open Fire Waste } \\
\text { Burning }\end{array}$ & 1 & - & - & - & - & - \\
\hline $\begin{array}{l}\text { Controlled } \\
\text { Landfills/Deposits }\end{array}$ & 0.01 & 0.0001 & - & - & - & - \\
\hline $\begin{array}{l}\text { Informal Dumping of } \\
\text { General Waste }\end{array}$ & 0.1 & 0.1 & 0.8 & - & - & - \\
\hline $\begin{array}{l}\text { Waste Water } \\
\text { System/Treatment }\end{array}$ & - & 0.5 & 0.2 & - & 0.15 & 0.15 \\
\hline
\end{tabular}




\section{CHAPTER 5}

\section{DEVELOPING MERCURY INVENTORY}

There are different anthropogenic activities contributing to mercury releases to the different environmental compartments. These activities can be grouped into five major categories. The first category is energy consumption and fuel production. This group includes coal, biomass and charcoal combustion, oil and natural gas production, refining and combustion with the aim of electricity and heat production. The second one is domestic production of metals and raw materials like copper production from concentrates, alumina production from bauxite, gold extraction without mercury amalgamation and cement production. The third category is the intentional use of mercury in industrial processes and products. It includes the use of mercury during production processes like vinly chloride monomer, acetaldehyde and chlor-alkali production, and the use of mercury in consumer products like thermometers, light sources, batteries, electrical switches and relays and dental amalgam fillings throughout their lifecycles, both production and use. The fourth group of activities includes crematoria and cemeteries. Finally, in the fifth group, activities regarding to general waste management like hazardous and municipal solid waste management and wastewater treatment are covered (UNEP-CB, 2013b).

Above-mentioned activities cause the release of mercury intentionally used or naturally found in the lithosphere. In this chapter, for the formation of mercury inventory of Turkey; as the first step, present sources contributing to mercury releases to the environment are determined. After that, mercury flows required for the development of SFA of mercury in Turkey are estimated by using UNEP Mercury Toolkit Level 1. 


\subsection{Mercury Releases from Energy Consumption and Fuel Production}

Objective of this section is to determine possible sources and estimate annual releases of mercury from sources to different environmental compartments as a result of activities related to energy consumption and fuel production in Turkey. Under this section, mercury release sources from energy and heat production activities are studied to determine mercury release estimates.

Since fossil fuel and biomass contain trace amounts of mercury, they contribute to mercury releases to the environment. Mercury is released to atmosphere as a result of fossil fuel and biomass burning. On the other hand, some of the releases to the atmosphere are captured by air pollution reduction equipment and end up in residue as bottom ash or fly ash. Landfills are usually the ultimate points to these sources (Jasinski, 1995). Therefore, in this section all possible releases from different sources related to energy consumption and fuel production are considered.

Major sources in this category are coal combustion in large power plants, other coal uses like combustion in smaller power plants and residential use, mineral oil and natural gas extraction, refining and consumption. Sub-categories covered under this section are given in Table 4. The first step is identification of sub-categories which are present in Turkey. Identified mercury release sources under this category are shown in Table 4.

Since there is no specific data about the quality of natural gas consumed in Turkey, it is all considered as cleaned pipeline quality and use of raw or pre-cleaned natural gas sub-category is not taken as a source. Moreover, charcoal combustion category is not studied in order to prevent double counting because it has already included in other coal uses. The next step is to go over one by one all sub-categories, collect necessary activity rate data, which is the fossil fuel produced or used in Turkey in a year, from different sources and estimate mercury releases to environmental compartments with the help of distribution factors. 
Table 4: Sub-categories covered under Energy Consumption and Fuel Production Category and their existence in Turkey

\begin{tabular}{|l|c|}
\hline Fuel Consumption & Existence \\
\hline Coal combustion in large power plants(above 300 MW) & Yes \\
\hline Other coal uses (sum for all other uses) & Yes \\
\hline Combustion/use of petroleum coke and heavy oil & Yes \\
\hline Combustion/use of diesel, gasoil, petroleum, kerosene & No \\
\hline Use of raw or pre-cleaned natural gas & Yes \\
\hline Use of pipeline gas (consumer quality) & Yes \\
\hline Biomass fired power and heat production (wood, etc.) & No \\
\hline Charcoal combustion & Yes \\
\hline Fuel Production & Yes \\
\hline Oil extraction & Yes \\
\hline Oil refining & \\
\hline Extraction and processing of natural gas & \\
\hline
\end{tabular}

\subsubsection{Coal Combustion in Large Power Plants}

This sub-category covers coal combustion for electricity and heat production in large power plants with capacity above $300 \mathrm{MW}$. It is considered as substantial source because they form high portion of coal consumption (UNEP-CB, 2013b). Mercury in coal is thermally released to atmosphere during combustion process. Releases from this activity depend on mercury concentration of coal used.

Turkey's annual coal combustion is found as 100.1 million tons of which 26.2 million tons are bituminous coal and 73.9 million tons are lignite in 2011 (TCE, 2013). Bituminous coal and lignite consumption in Turkey according to their usage areas are presented in Figure 3 and Figure 4. Therefore, activity rate data, which is the total of both bituminous coal and lignite combusted with the aim of electricity production, is accepted as 70.34 million tons annually depending on the data presented in Table 5. 


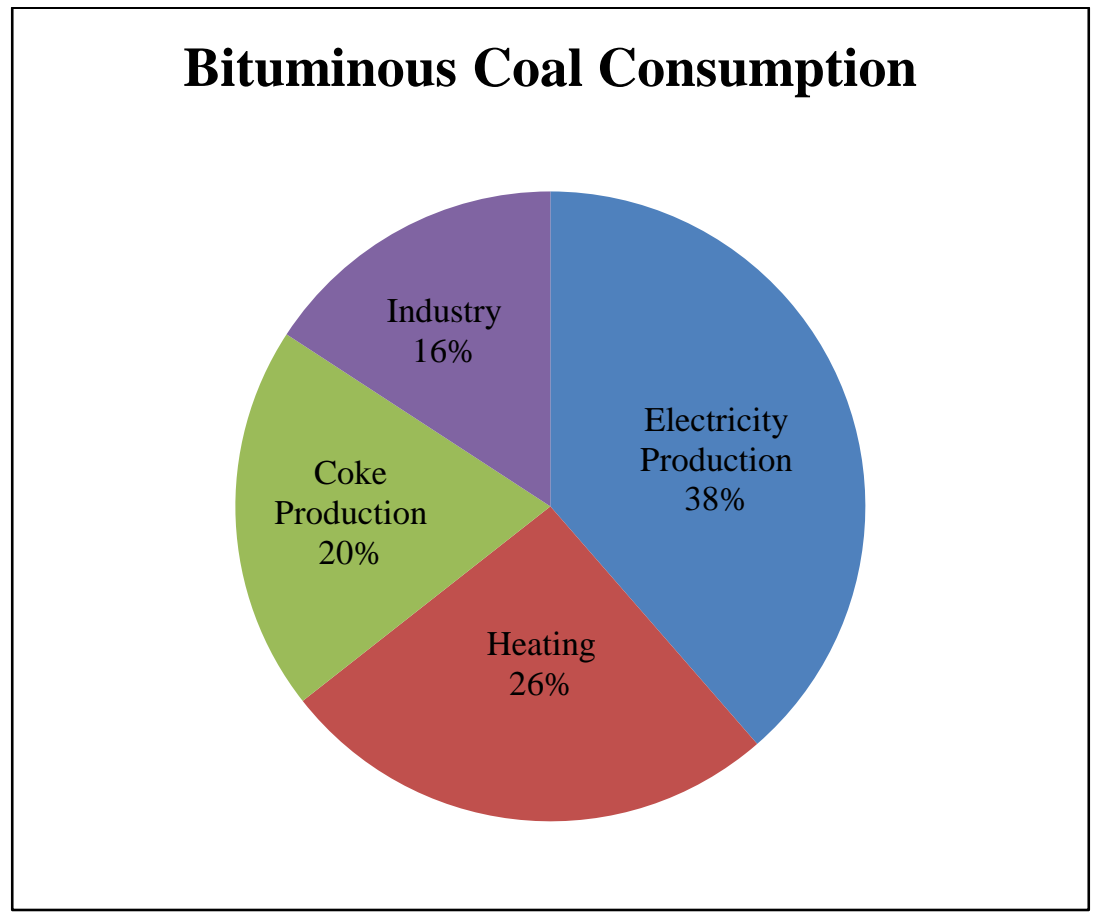

Figure 3: Bituminous coal consumption in Turkey in 2011 (TCE, 2013)

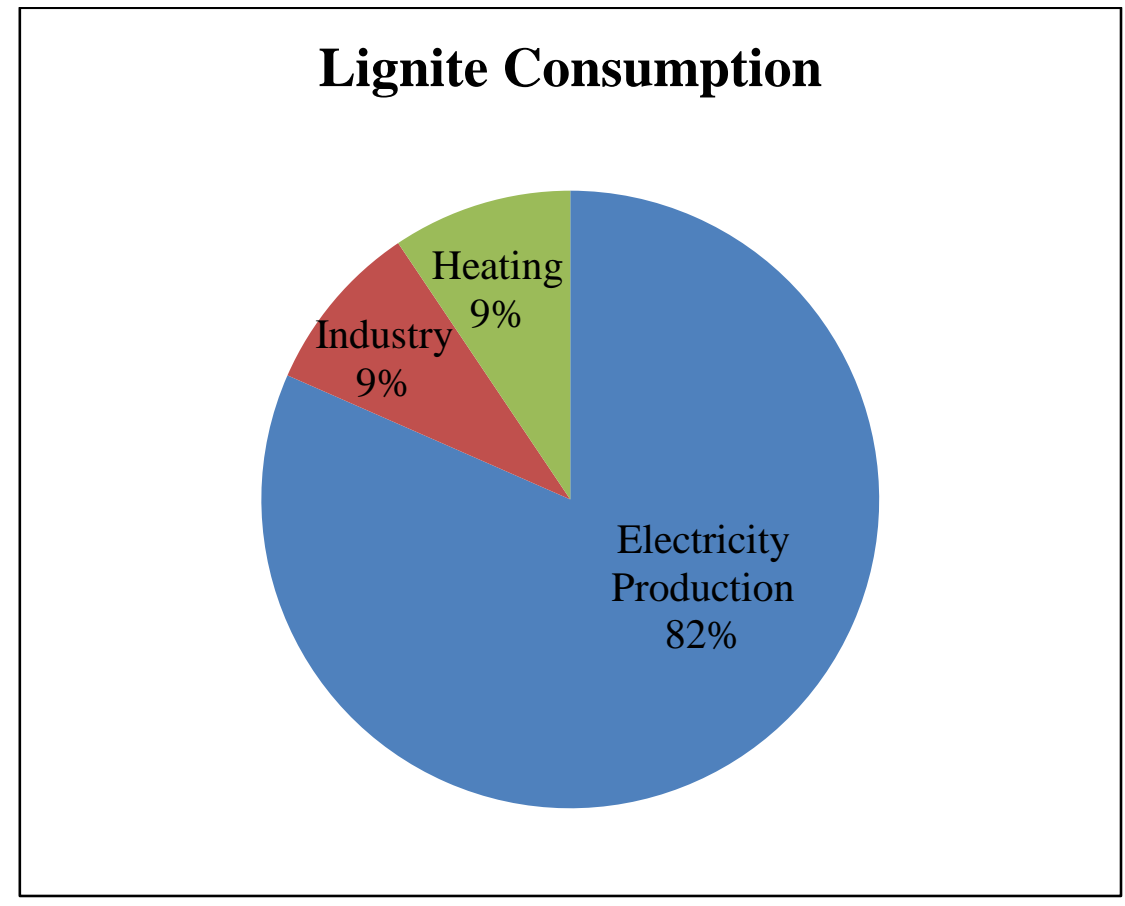

Figure 4: Lignite consumption in Turkey in 2011 (TCE, 2013) 
Table 5 : Amounts of coal consumed in Turkey in 2011 (TCE, 2013)

\begin{tabular}{|l|c|l|c|}
\hline \multicolumn{1}{|c|}{ Use Area } & $\begin{array}{c}\text { Bituminous } \\
\text { Coal } \\
\text { Consumption } \\
\left(\mathbf{x 1 0}^{\mathbf{6}} \mathbf{t} / \mathbf{y}\right)\end{array}$ & Use Area & $\begin{array}{c}\text { Lignite } \\
\text { Consumption } \\
(\mathbf{x 1 0} \mathbf{6} \text { t/y })\end{array}$ \\
\hline Electricity Production & 10.11 & Electricity Production & 60.23 \\
\hline Heating & 6.76 & Industry & 6.65 \\
\hline Coke Production & 5.19 & Heating & 6.95 \\
\hline Industry & 4.14 & & 73.9 \\
\hline Total Use & 26.2 & & \\
\hline
\end{tabular}

For developing the inventory, calculations are done based on general mix of $1 / 3$ bituminous, $1 / 3$ sub-bituminous and 1/3 lignite. Default mercury input factor of 0.15 $\mathrm{g} \mathrm{Hg} / \mathrm{t}$ of coal combusted from the range given in Table 6 is used for the calculation of mercury input (UNEP-CB, 2013b). As it can be seen in Table 7, default input factor defined by UNEP in the toolkit is very close to the value defined by Finkelman (2004) for Turkish coals.

Table 6: Input factor range for mercury in coal used in power plants for energy production (UNEP-CB, 2013b)

\begin{tabular}{|c|c|}
\hline \multicolumn{1}{|c|}{ Material } & $\begin{array}{c}\text { Input factor } \\
\text { (g mercury/ton of coal) }\end{array}$ \\
\hline Coal used in power plants & $0.05-0.5$ \\
\hline
\end{tabular}

Table 7: Mercury concentrations of Turkish coals (Finkelman, 2004 as cited in UNEP, 2013b)

\begin{tabular}{|c|c|c|c|}
\hline Origin & Coal Type & $\begin{array}{c}\text { Mean Hg } \\
\text { Concentration }\end{array}$ & $\begin{array}{c}\text { Range of Hg Concentrations } \\
\text { (Number of samples taken) }\end{array}$ \\
\hline Turkey & Lignite & $0.11 \mathrm{~g} / \mathrm{t}$ & $0.03-0.66 \mathrm{~g} / \mathrm{t}(143)$ \\
\hline
\end{tabular}


Therefore, activity rate data which is 70.34 million t/y is multiplied with mercury content of the coal (input factor) and estimated mercury input is calculated as;

$$
70.34 \times 10^{6} \frac{t}{y} \times 0.15 \frac{g H g}{t}=10551 \frac{\mathrm{kg}}{y}
$$

Another important point is air pollution control systems used in power plants because they affect amount of mercury releases to the environmental compartments. It is assumed that power plants use "Particulate Matter Simple APC: Electrostatic Separator (ESP)/ Particle scrubber (PS)/ Cyclone (CYC)" as air pollution control units and distributes mercury input as air releases, incineration residues and flue gas cleaning residues (UNEP-CB, 2013b). Calculated outputs are;

$$
10551 \frac{\mathrm{kg}}{\mathrm{y}} \times 0.88=9284.9 \frac{\mathrm{kg}}{\mathrm{y}} \text { air releases }
$$

$10551 \frac{\mathrm{kg}}{\mathrm{y}} \times 0.12=1266.1 \frac{\mathrm{kg}}{\mathrm{y}}$ sector specific waste treatment $/$ disposal

\subsubsection{Other Coal Uses}

Under this sub-category coal combustion in smaller combustion plants which are below the $300 \mathrm{MW}$, industrial combustion/ boilers in different sectors, household use of coal and production and use of coke are covered. According to European Union (2005) small combustion plants and residential heating are important sources of mercury releases, also small combustion plants can be more important sources compared to large combustion plants because they may not as well controlled as large plants. In addition, coke production and use is another source for mercury releases since it is produced from coal by carbonization process (UNEP-CB, 2013b).

For this category, calculations are done based on the coal mixture of $1 / 3$ bituminous, 1/3 sub-bituminous and 1/3 lignite as for coal combustion in large power plants and it is assumed that combustion takes place without any air pollution control units. 
Mercury content of $0.13 \mathrm{~g} / \mathrm{t}$ coal, which is defined in UNEP toolkit as default factor, is used for the calculation (UNEP-CB, 2013a), since default factor is very close to the value found by Finkelman (2004) for Turkish coals as given in Table 7.

Coal consumption for heating, coke production and industrial use are included during estimation of mercury releases from this category. Activity rate data is accepted as 29.69 million $\mathrm{t} / \mathrm{y}$ of coal according to data presented in Table 5. Thus estimated mercury input to the environment from this category is calculated by multiplying coal consumption rate with coal content as;

$$
29.69 \times 10^{6} \frac{t}{y} \times 0.13 \frac{g H g}{t}=3859.7 \frac{\mathrm{kg}}{y}
$$

For this category, combustion with no air pollution unit is assumed and all mercury input is assumed to become by releases to air directly (UNEP-CB, 2013b). Therefore, an estimated mercury release to air is found as $3859.7 \mathrm{~kg} / \mathrm{year}$.

\subsubsection{Oil Extraction, Refining and Use}

Mercury naturally exists in the oil (known as petroleum oil and mineral oil) . Naturally existing mercury in the oil is released to the environment during extraction, refining and use of oil and its products. This sub-category covers all these possible steps where mercury releases can occur.

First of all, releases are resulted from extraction of crude oil. Mercury content of crude oil is highly variable depending on the reservoir and geographical region (Littlepage, 2013). However, for the estimation of releases from this source, default mercury input factor, which is defined as $3.4 \mathrm{mg} /$ ton crude oil by UNEP, is used for calculating the amount of mercury input to the environment (UNEP-CB, 2013a). The ranges defined for the mercury content of crude oil and its products are presented in Table 8. 
Table 8: Input factor range for mercury in oil (UNEP-CB, 2013b)

\begin{tabular}{|l|c|}
\hline \multicolumn{1}{|c|}{ Oil Product } & \multicolumn{1}{|c|}{$\begin{array}{c}\text { Input factor } \\
\text { (mg mercury/ton of oil ) }\end{array}$} \\
\hline Crude oil & $1-66$ \\
\hline $\begin{array}{l}\text { Petrol/gasoline, diesel, distilled fuel oil, } \\
\text { kerosene and other light distillates }\end{array}$ & $1-10$ \\
\hline Petroleum coke and heavy oil & $10-100$ \\
\hline
\end{tabular}

Turkey's annual oil extraction amount obtained from Turkish Energy Report as 2.4 million tons in 2011 (WEC, 2013). Then, mercury input amount from oil extraction is calculated as;

$$
2.4 \times 10^{6} \frac{\mathrm{t}}{\mathrm{y}} \times 3.4 \frac{\mathrm{mg} \mathrm{Hg}}{\mathrm{t}}=8.16 \frac{\mathrm{kg}}{\mathrm{y}}
$$

It is assumed that $20 \%$ of mercury input is released to water while $80 \%$ of it remains in the oil (UNEP-CB, 2013b). Therefore, release to water environment from extraction of oil is calculated as follows;

$$
8.16 \frac{\mathrm{kg}}{\mathrm{y}} \times 0.2=1.6 \frac{\mathrm{kg}}{\mathrm{y}} \text { water release }
$$

After extraction, crude oil is separated in refineries by cracking. At the end of this process, different types of oil products are formed as shown in Figure 5. They can basically grouped into two; one is heavy fuel oil including petroleum coke and heavy oil and other group is light fuel oil like diesel, gasoil, petroleum and kerosene. Basic idea behind the oil refining is to separate oil by distillation process using different boiling points (UNEP-CB, 2013b). For example, gas is the product with lowest boiling point and residue has the highest boiling point as shown in Figure 5. Mercury is released to the environment during the refining process; however, some portion of it remains in the products and released during the use. 


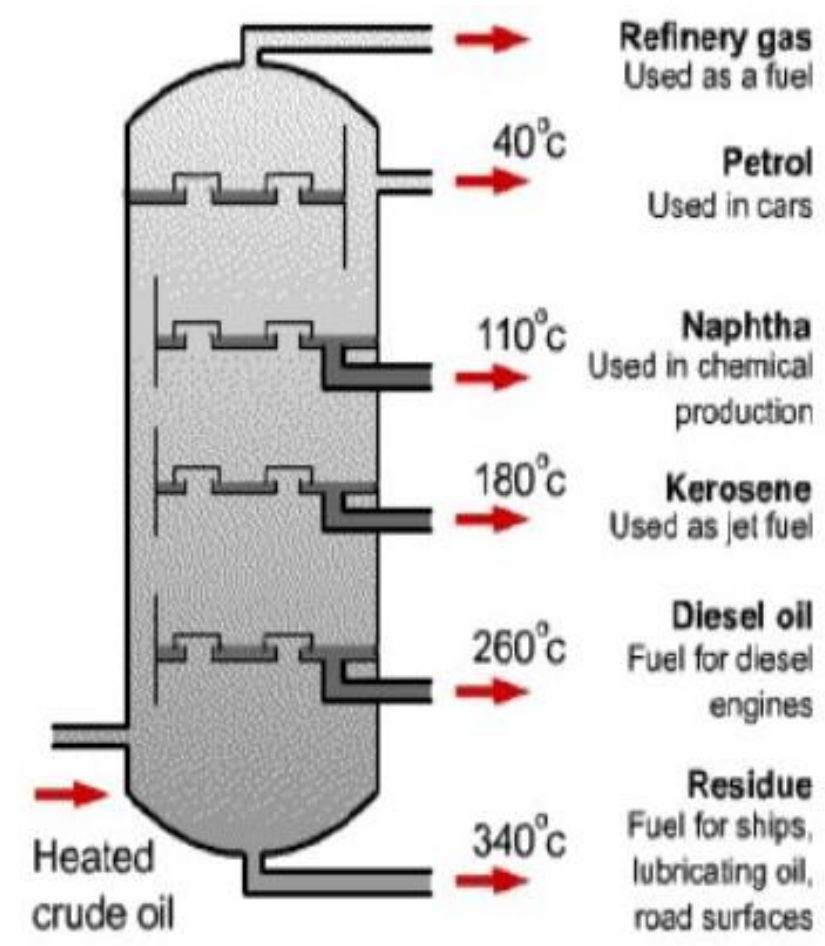

Figure 5: Crude oil distillation process (Littlepage, 2013)

Mercury input factor for oil refining is taken as $3.4 \mathrm{mg} / \mathrm{t}$ crude oil since it is taken as mercury in the crude oil as given in

According to World Energy Council (2012) in 2011, 21 million crude oil is processed in Turkish refineries. Mercury input value from this process is;

$$
21 \times 10^{6} \frac{\mathrm{t}}{y} \times 3.4 \frac{\mathrm{mg} \mathrm{Hg}}{\mathrm{t}}=71.4 \frac{\mathrm{kg}}{\mathrm{y}}
$$

Mercury releases from this process is calculated as $17.9 \mathrm{~kg} / \mathrm{y}$ to air, $0.7 \mathrm{~kg} / \mathrm{y}$ to water and $10.7 \mathrm{~kg} / \mathrm{y}$ is handled in sector specific waste treatment/disposal according to output distribution factors (Table 3) used for this category (UNEP-CB, 2013a).

As mentioned before, remaining mercury is released during combustion/use of oil products produced. In order to determine releases from these sources, petroleum products used in Turkey are gathered from Turkish Petroleum Industry Report (TPC, 
2013) as in two main categories. One of them is combustion/use of petroleum coke and heavy oil. For this category Turkey's annual petroleum coke, asphaltite and bitumen consumption amounts are gathered. Petroleum coke demand are found as 2620 tons per year and asphaltite demand is 865 thousand per year (WEC, 2013). Since according to TPC (2013), 13\% of petroleum refined in refineries is bitumen and about $80 \%$ of bitumen used in road building, total bitumen demand is found as 2185 thousand tons per year. Therefore, combustion/use of petroleum coke and heavy oil is found as 5670 thousand tons/year. Mercury input factor for this category is taken as the intermediate value of $55 \mathrm{mg} / \mathrm{t}$ heavy petroleum product from the given range in Table 8 . Therefore, mercury input calculation is;

$$
5670 \times 10^{3} \frac{\mathrm{t}}{\mathrm{y}} \times 55 \frac{\mathrm{mg} \mathrm{Hg}}{\mathrm{t}}=312 \frac{\mathrm{kg}}{\mathrm{t}}
$$

When calculating the output from combustion/use of petroleum coke and heavy oil no emission control is assumed when deciding on output distribution factors. Mercury input with this category is all assumed to become releases to air. Thus, air release from this activity is found as $312 \mathrm{~kg} / \mathrm{t}$.

Other category is combustion/use of diesel, gasoil, petroleum and kerosene. Since according to TPC (2013), 79\% of petroleum processed in refineries belong to this category and the amount of petroleum annually processed in facilitates in Turkey is 21 million tons (WEC, 2013), 16590 thousand tons/year diesel, gasoil, petroleum and kerosene combustion is assumed in Turkey in 2012. Mercury input factor is determined as $5.5 \mathrm{mg} \mathrm{Hg} /$ ton which is the medium value of range in Table 8. Input value calculation is;

$$
16590 \times 10^{3} \frac{t}{y} \times 5.5 \frac{\mathrm{mg} \mathrm{Hg}}{t}=91 \frac{\mathrm{kg}}{\mathrm{y}}
$$

For the determination of output distribution factors no air pollution control is assumed and releases assumed to be as air releases. Therefore, release to air is found as $91 \mathrm{~kg} / \mathrm{y}$. 


\subsubsection{Natural Gas Extraction, Processing and Use}

Natural gas is extracted and use for different purposes, especially for electricity production and heating. Found naturally in all hydrocarbons, natural gas contains mercury impurities which are released to the environment during extraction, processing and use. In this category, mercury releases from all of these steps are estimated. During extraction and processing of natural gas, mercury in the gas is mobilized. Even amount of mercury in natural gas can change depending on the geography, for the calculation of mercury input from this activity, mercury input factor of $100 \mu \mathrm{g} \mathrm{Hg} / \mathrm{Nm}^{3}$ is used for extraction and processing steps (UNEP-CB, 2013b). Input factor range of mercury for natural gas is given in Table 9.

Table 9: Input factor range for mercury in natural gas (UNEP-CB, 2013b)

\begin{tabular}{|l|c|}
\hline \multicolumn{1}{|c|}{ Gas Quality } & $\begin{array}{c}\text { Input factor } \\
\left(\boldsymbol{\mu g} \text { mercury } / \mathbf{N m}^{\mathbf{3}}\right)\end{array}$ \\
\hline Raw or pre-cleaned gas & $2-200$ \\
\hline Pipeline gas (consumer quality) & $0.03-0.4$ \\
\hline
\end{tabular}

Natural gas extracted and processed in Turkey in 2011 is found as 793 million $\mathrm{m}^{3}$ (WEC, 2013). Mercury input from this activity is calculated by multiplying activity rate data which is the natural gas extracted in a year with input factor as follows;

$$
793 \times 10^{6} \frac{\mathrm{m}^{3}}{y} \times 100 \frac{\mu \mathrm{g} \mathrm{Hg}}{\mathrm{m}^{3}}=79.3 \frac{\mathrm{kg}}{y}
$$

Some of the natural gas extraction and processing plants use mercury removal units, some do not. Output distribution is done based on the scenario of $50 \%$ of natural gas processed with mercury removal unit and $50 \%$ processed without mercury removal unit by using output distribution factors given in Table 3. Mercury releases to the environment are found as $11.9 \mathrm{~kg} / \mathrm{y}$ to air, $15.9 \mathrm{~kg} / \mathrm{y}$ to water and $23.8 \mathrm{~kg} / \mathrm{y}$ as byproduct and impurities and $27.8 \mathrm{~kg} / \mathrm{y}$ sector specific treatment/disposal. 
Mercury is released to the environment during the use of processed natural gas. Since there is no specific data about the quality of natural gas consumed in Turkey, all natural gas consumed is assumed to have consumer quality (known as pipeline gas). Turkey's natural gas consumption for the year of 2011 is found as $44.1{\text { billion } \mathrm{m}^{3}}^{3}$ (WEC, 2013). For the calculation of mercury input from this activity to the environment, mercury input factor of medium value which is $0.2 \mu \mathrm{g} \mathrm{Hg} / \mathrm{Nm}^{3}$ is chosen as given in Table 9. Mercury input is calculated as;

$$
44.1 \times 10^{9} \frac{\mathrm{m}^{3}}{y} \times 0.2 \frac{\mu \mathrm{g} \mathrm{Hg}}{\mathrm{m}^{3}}=10 \frac{\mathrm{kg}}{\mathrm{y}}
$$

It is assumed that $100 \%$ of this value is released to air (UNEP-CB, 2013b). Therefore, air release is calculated as $10 \mathrm{~kg} \mathrm{Hg} / \mathrm{y}$ for the use of pipeline quality natural gas.

\subsubsection{Biomass Fired Power and Heat Production}

Power and heat can be produced from combustion of biomass like wood, twigs, bark, sawdust, wood shavings and agricultural residues. In industry and residential applications, this way of energy production can be preferred. In this category, biomass combustion in wood-fired boilers, wood stoves and fireplaces are considered as sources (UNEP-CB, 2013b). For the calculation of mercury input from this category, mercury input factor for biomass burned is used as $0.03 \mathrm{~g} / \mathrm{t}$ from the range given in Table 10.

Table 10: Input factor range for mercury in biomass used for energy production

(UNEP-CB, 2013b)

\begin{tabular}{|c|c|}
\hline \multicolumn{1}{|c|}{ Material } & $\begin{array}{c}\text { Input factor } \\
\text { (g mercury/ton) }\end{array}$ \\
\hline Biomass used in combustion (principally wood) & $0.007-0.07$ \\
\hline
\end{tabular}


For this source, amount of biomass combusted in Turkey for energy production is found from World Energy Council's Turkey's Energy Report 2012 as 8154 thousand tons for the year 2011. All biomass combusted assumed to be wood. Mercury input from this category is calculated as;

$$
8154 \times 10^{3} \frac{t}{y} \times 0.03 \frac{g H g}{t}=245 \frac{k g}{y}
$$

It is assumed that all of the mercury input from this source is turned into air releases when calculating the estimated mercury releases to the environment (UNEP-CB, 2013b). Therefore, mercury output from biomass fired power and heat production is assumed as $245 \mathrm{~kg} / \mathrm{y}$ air release.

\subsection{Mercury Releases from Domestic Production of Metals and Raw Materials}

In this section, activities regarding to domestic production of metals and raw materials in Turkey are determined and annual mercury releases from these activities to the environment are estimated.

This section covers mainly three groups of activities: 1) Primary production of metals 2) gold mining 3) production of materials; cement and paper. The source for mercury releases during the mining and primary production of metals and materials is the trace amounts of mercury existing in the ore released to the environment during the activities. In gold mining, the source for mercury release can be the technique of gold extraction with mercury amalgamation as well as mercury itself in the ore processed. Raw materials, naturally containing mercury, like fossil fuels and woods used during the production of materials, are the sources for mercury releases during the production of materials; cement and paper (UNEP-CB, 2013a). Therefore, it can be concluded that mercury releases to the environment can occur as a result of activities mentioned.

In order to estimate mercury releases some subcategories are studied as shown in Table 11. First of all, existence of these subcategories in Turkey is investigated. 
Mercury extraction and processing is not a valid source for Turkey, because most of the mercury production mines were closed during 1990s and today there is no mercury production in Turkey because of the declining foreign sale as a result of use of alternatives and environmental concerns (MoEU, 2010). Since Turkey does not have enough metal ore processing capacity, ores extracted in Turkey are exported while required metals are imported. There is only a facility processing copper in Turkey, however, there is not any to process zinc and lead ores and concentrates. Therefore, production of zinc and lead from their concentrates are not valid sources for Turkey (SPO, 2006). It is known that techniques of gold extraction with mercury amalgamation- with and without use of resort are not used in Turkey, thus are not taken as sources for mercury releases. Moreover, since there is not any pulp production and the imported pulp is used for the production of paper in Turkey, pulp and paper production is not considered as a source for mercury releases in this study.

Table 11: Sub-categories covered under Domestic Production of Metals and Raw Materials and their existence in Turkey

\begin{tabular}{|l|c|}
\hline Primary metal production & Existence \\
\hline Mercury extraction and initial processing & No \\
\hline Production of zinc from concentrates & Yes \\
\hline Production of copper from concentrates & No \\
\hline Production of lead from concentrates & Yes \\
\hline Gold extraction by methods other than mercury amalgamation & Yes \\
\hline Alumina production from bauxite (aluminum production) & No \\
\hline Primary ferrous metal production (pig iron production) & No \\
\hline Gold mining with mercury amalgamation & \\
\hline $\begin{array}{l}\text { Gold extraction with mercury amalgamation- without use of } \\
\text { resort }\end{array}$ & Yes \\
\hline Gold extraction with mercury amalgamation- with use of retort & No \\
\hline Other materials production & \\
\hline Cement production & \\
\hline Pulp and paper production & \\
\hline
\end{tabular}


After determination of existence of possible sources for mercury releases in Turkey, activity rate data for each subcategory are gathered. By using activity rate data and distribution factors, estimated mercury releases from activities are calculated.

\subsubsection{Production of Copper from Concentrates}

Copper ore usually contains trace amounts of mercury that can be released to the environment from rock material due to extraction. During copper production process, firstly concentrate is produced from the raw ore and after that, concentrate is gone under roasting process and smelted in a furnace at high temperatures. This process includes numerous steps, and a final step named as "converting" aiming to remove iron ad sulphur and leave copper. Facilities applying this whole process for copper production are known as "primary cooper smelters".

Mercury releases can occur during the roasting/drying process and from smelting in furnace. Moreover, converters and refining furnaces can emit residual mercury remaining in the process. If there is no precaution to remove mercury in the off gas treatment before the acid plant, most of the releases will be to the atmosphere (UNEP-CB, 2013b). In this study, mercury input factor of $30 \mathrm{~g} \mathrm{Hg} / \mathrm{t}$ is used which is the default value of the toolkit as shown in Table 12.

Table 12: Input factor range for mercury in concentrates for copper production

(UNEP-CB, 2013b)

\begin{tabular}{|l|c|}
\hline \multicolumn{1}{|c|}{ Material } & $\begin{array}{c}\text { Input factor } \\
\text { (g mercury/ton of concentrate) }\end{array}$ \\
\hline Copper concentrate & $1-100$ \\
\hline
\end{tabular}

Since it is very hard to find consumption data for mining products, the only way is to use the most recent data. Unfortunately, the only available data for the consumption of copper concentrate in Turkey is for the years 1999-2005 as shown in Table 13. For 
the calculation of mercury input, copper concentrate consumed in Turkey for the year of 2005 which is 157000 tons/year is used (SPO, 2006).

Table 13: Amount of copper concentrate consumed in Turkey between 1999-2005 (SPO, 2006)

\begin{tabular}{|c|c|c|c|c|c|c|c|}
\hline & 1999 & 2000 & 2001 & 2002 & 2003 & 2004 & 2005 \\
\hline $\begin{array}{c}\text { Copper Concentrate } \\
\begin{array}{c}\text { Consumed (1000 } \\
\text { tons/year) }\end{array}\end{array}$ & 145 & 182 & 185 & 115 & 176 & 53 & 157 \\
\hline
\end{tabular}

In order to calculate mercury input from copper production from concentrates, activity rate data is multiplied with mercury content of copper concentrate (input factor) and estimated mercury input is calculated as;

$$
157000 \frac{t}{y} \times 30 \frac{g H g}{t}=4710 \frac{\mathrm{kg}}{y}
$$

While calculating mercury releases from this activity, smelters with wet gas cleaning and acid plant is assumed for the determination of output distribution. Mercury releases are found as $471 \mathrm{~kg} \mathrm{Hg} / \mathrm{y}$ to air, $94.2 \mathrm{~kg} \mathrm{Hg} / \mathrm{y}$ to water, $1978.2 \mathrm{~kg} \mathrm{Hg} / \mathrm{y}$ as by products and impurities and $2166.6 \mathrm{~kg} \mathrm{Hg} / \mathrm{y}$ as sector specific waste treatment/disposal by multiplying the output distribution factors with the mercury input calculated above.

\subsubsection{Gold Extraction by Methods other than Mercury Amalgamation}

Some gold ore may contain high mercury amounts as much as gold concentrations. Gold extraction process is a very important source for mercury releases all around the world, even if mercury amalgamation methodology is not used (UNEP-CB, 2013b). USA and Russia are the largest contributors to the Artic Atmospheric mercury releases because of the gold extraction processes existing. It should be 
noticed that the source for mercury releases is the mercury naturally existing in the ore because mercury amalgamation method used in small scale gold mining is not used anymore in USA and it is illegal in Russia (ACAP, 2005).

Since mercury content of the gold ore can vary a lot, for a better estimation of mercury input from gold extraction the amount of $\mathrm{Hg}$ in gold ore is found from Kışladağ Gold Mine Capacity Increasing Report as 1 ppm (Canadian Environmental and Metallurgical Inc., 2006) The found value is also in the range given in Table 14 by UNEP.

Table 14: Input factor range for mercury in the gold ore (UNEP-CB, 2013b)

\begin{tabular}{|l|c|}
\hline Material & $\begin{array}{c}\text { Input factor } \\
\text { (g mercury/ton of ore })\end{array}$ \\
\hline Gold ore & $1-30$ \\
\hline
\end{tabular}

Amount of gold extracted in Turkey has showed an increase in the last decade. In 2011, 24.4 tons of gold is produced (MoENR, 2013). Since input factor is available in terms of amount of mercury in gold ore and activity rate data is available as gold produced in a year, unit conversion of the activity rate data is required for the calculation of mercury input from this activity. With that purpose, conversion factor which is $4 \mathrm{~g}$ gold/t ore is used and activity rate data for gold extraction is recalculated as (UNEP-CB, 2013b);

$$
24.4 \frac{t \text { gold }}{y} \times \frac{1 \text { tore }}{4 \text { g gold }}=6100000 \frac{t \text { ore }}{y}
$$

For the calculation of mercury input estimate from this sub-category, activity rate data is multiplied with input factor and it is found as;

$$
6100000 \frac{t}{y} \times 1 \frac{g H g}{t}=6100 \frac{\mathrm{kg}}{y}
$$


By multiplying estimated mercury input value with the output distribution factors, estimated mercury output values from gold extraction by methods other than mercury amalgamation are calculated as;

$$
\begin{gathered}
6100 \frac{\mathrm{kg}}{\mathrm{y}} \times 0.04=244 \frac{\mathrm{kg}}{\mathrm{y}} \text { air releases } \\
6100 \frac{\mathrm{kg}}{\mathrm{y}} \times 0.02=122 \frac{\mathrm{kg}}{\mathrm{y}} \text { water releases } \\
6100 \frac{\mathrm{kg}}{\mathrm{y}} \times 0.9=5490 \frac{\mathrm{kg}}{\mathrm{y}} \text { land releases } \\
6100 \frac{\mathrm{kg}}{\mathrm{y}} \times 0.04=244 \frac{\mathrm{kg}}{\mathrm{y}} \text { by product and impurities }
\end{gathered}
$$

\subsubsection{Alumina Production from Bauxite (Aluminum Production)}

Aluminum production is one of the most important sources of mercury releases to the environment. However, since alumina production is dominated by few countries having the major bauxite deposits, it may not be a major source for all countries. During the production of alumina, bauxite ore is refined into alumina and then reduced to metallic aluminum by electrolytically. During the process, trace amounts of mercury in feed ore, fossil fuels and hydrocarbon auxiliary materials are released to the environment (UNEP-CB, 2013b).

For the estimation of mercury input to the environment from alumina production from bauxite, default input factor which is $0.5 \mathrm{~g} \mathrm{Hg} / \mathrm{t}$ bauxite from the range shown in Table 15, is used for calculation. 
Table 15: Default input factor range for mercury in bauxite (UNEP-CB, 2013b).

\begin{tabular}{|c|c|}
\hline \multicolumn{1}{|c|}{ Process } & $\begin{array}{c}\text { Input factor } \\
\text { (g mercury/ton of bauxite) }\end{array}$ \\
\hline Production of alumina & $0.07-1$ \\
\hline
\end{tabular}

In Turkey, there is only one plant processing bauxite for the production of alumina which is Eti Aluminium Plant in Seydişehir (SPO, 2006). This plant has 400000 tons of bauxite processing capacity. Therefore, activity rate data for the calculation of mercury input from alumina production activity is taken as 400000 tons/year. For the calculation of mercury input, estimated activity rate data is multiplied with default input factor as follows;

$$
400000 \frac{t}{y} \times 0.5 \frac{g H g}{t}=200 \frac{\mathrm{kg}}{y}
$$

Multiplying mercury input value with output distribution factors, estimated releases from this activity to different environmental compartments are found as;

$$
\begin{gathered}
200 \frac{\mathrm{kg}}{\mathrm{y}} \times 0.15=30 \frac{\mathrm{kg}}{\mathrm{y}} \text { air releases } \\
200 \frac{\mathrm{kg}}{\mathrm{y}} \times 0.1=20 \frac{\mathrm{kg}}{\mathrm{y}} \text { water releases } \\
200 \frac{\mathrm{kg}}{\mathrm{y}} \times 0.65=130 \frac{\mathrm{kg}}{\mathrm{y}} \text { general waste } \\
200 \frac{\mathrm{kg}}{y} \times 0.1=20 \frac{\mathrm{kg}}{\mathrm{y}} \text { sector specific waste treatment }
\end{gathered}
$$




\subsubsection{Primary Ferrous Metal Production (Pig Iron Production)}

Iron and steel industry can be an important source for the mercury releases since high amounts of coal and iron ore containing mercury impurities are used (Fukuda et al., 2011). Feed materials, especially ore and lime are the major sources determining mercury releases from this industry. In this sector, by smelting iron ore, molten or solid form pig iron is produced, and then with the removal of carbon in the iron, pig iron is converted into steel (UNEP-CB, 2013b). Sintering process is the pre-step of pig iron production where fine particles in the ores are agglomerated. These plants prepare iron ore by producing agglomerated product (sinter) for blast furnace step where iron is produced. Sintering and blast furnace steps can be treated as an one step for mercury releases because they come out with the pig-iron as the output (UNEP-CB, 2013b). Mercury releases can occur at different points during ferrous metal production. However, usually sintering plants are the greatest contributors of mercury releases to environment (Fukuda et al., 2011).

Emission factor for sinter plants is given as $0.049 \mathrm{~g} \mathrm{Hg} /$ metric ton of sinter produced in Emission Guidebook prepared by EMEP/EEA (EMEP/EEA, 2013). In this study, for the calculation of mercury input from primary ferrous metal production (pig production) including sintering and blast furnace steps, input factor of $0.05 \mathrm{~g} \mathrm{Hg} /$ metric ton pig iron produced is used (UNEP-CB, 2013b).

Activity rate data which is the amount of pig iron produced in Turkey in the year of 2012 is found from Turkish Iron and Steel Industry Report as 35.8 million tons (MoSIT, 2013b). In order to determine mercury input from this activity, activity rate data is multiplied with the input factor given above as;

$$
35800000 \frac{t}{y} \times 0.05 \frac{g \mathrm{Hg}}{\mathrm{t}}=1790 \frac{\mathrm{kg}}{\mathrm{y}}
$$

Estimated mercury releases to the environment from primary ferrous metal production (pig iron production) are distributed to different environmental compartments by using the output distribution factors. $95 \%$ of mercury releases are 
in the form of atmospheric releases while 5\% of them end up in tailings which are landfilled. Therefore, estimated mercury releases from this activity are calculated as;

$$
\begin{gathered}
1790 \frac{\mathrm{kg}}{\mathrm{y}} \times 0.95=1700.5 \frac{\mathrm{kg}}{\mathrm{y}} \text { air releases } \\
1790 \frac{\mathrm{kg}}{\mathrm{y}} \times 0.05=89.5 \frac{\mathrm{kg}}{\mathrm{y}} \text { sector specific treatment } / \text { disposal }
\end{gathered}
$$

\subsubsection{Cement Production}

The reason for the contribution of cement production to the environmental mercury releases is the trace amounts of mercury in the raw materials used for the production. Even if cement production contains raw materials with small amounts of mercury, because of the large amounts it can be a major source for the mercury in environment. Mercury naturally presenting in raw materials like lime, coal and oil, solid residues coming from different sectors like fly-ashes and gypsum and wastes may contain high amounts of mercury and may be the major source for the releases from this activity (UNEP-CB, 2013b).

For the calculation of estimated mercury releases, it is assumed that $50 \%$ of the cement produced without co-incineration of waste while $50 \%$ of it produced with co-incineration of waste and default input factor for this activity which is defined as $0.13 \mathrm{~g} \mathrm{Hg} /$ tons of cement produced is used (UNEP-CB, 2013a).

Cement production in Turkey for the year of 2012 is found as 60.3 million tons from Turkish Cement Industry Report (MoSIT, 2013a). For the calculation of mercury input from cement production, activity data which is 60.3 million tons of cement is multiplied with the input factor which is $0.13 \mathrm{~g} \mathrm{Hg} / \mathrm{ton}$ of cement as follows;

$$
60300000 \frac{t}{y} \times 0.13 \frac{g \mathrm{Hg}}{\mathrm{t}}=7839 \frac{\mathrm{kg}}{\mathrm{y}}
$$


In order to determine estimated mercury releases from this activity, mixed output scenario of 50\% with "no filters" and 50\% "Simple particle control (ESP/ PS/ FF)" with dust recycling is assumed. Estimated mercury releases from this source are found as;

$$
\begin{gathered}
7839 \frac{\mathrm{kg}}{\mathrm{y}} \times 0.75=5879.3 \frac{\mathrm{kg}}{\mathrm{y}} \text { air releases } \\
7839 \frac{\mathrm{kg}}{\mathrm{y}} \times 0.25=1959.8 \frac{\mathrm{kg}}{\mathrm{y}} \text { by product and impurities }
\end{gathered}
$$

\subsection{Intentional Use of Mercury in Industrial Processes and Consumer Products}

In this section, industrial processes and products where mercury is used intentionally are studied to estimate annual mercury releases from these activities in Turkey. This section includes industrial production of chemicals, industrial production of mercury added products and their consumption.

Mercury is used during the production of chemicals like chlor-alkali, VCM (vinylchloride- monomer), acetaldehyde and other chemicals and polymers with different purposes and it can be released to air, water and land during the production processes. On the other hand, it is widely used in products because of its important properties like electricity conductivity, amalgamation with other metals and extension and contraction parallel to pressure and temperature changes (Cain et.al, 2007). Mercury can be released from mercury added products through their life cycles, not only during the production but during consumption and disposal. Therefore, in this study both production and consumption steps of these products are considered separately.

Sub-categories given in Table 16 are studied under this section. First of all, their existence is investigated. According to Turkish State Planning Organization, Chemicals Industry Commission's Development Plan for the years 2007-2013 (2008), mercury cell technology for chlor-alkali production has completely replaced 
with membrane electrolyzes since June, 2000. Therefore, chlor-alkali production with mercury cells is not considered as a source for Turkey. Likewise, it is determined that for the production of VCM (vinyl-chloride-monomer) instead of use of mercury- dichloride $\left(\mathrm{HgCl}_{2}\right)$ as catalyst, oxychlorination of ethylene (without use of mercury) is preferred and VCM production with mercury catalyst is not taken as a potential source for the mercury releases in Turkey. In addition, according to The Union of Chambers and Commodity Exchanges of Turkey-Industry Database, there is no acetaldehyde production in Turkey, making acetaldehyde production with mercury-cells invalid source (2013). It can be concluded that intentional use of mercury in industrial processes for the production of chemicals is not a potential source for the mercury releases in Turkey.

Production of electrical switches and relays with mercury is not considered as a source for Turkey, since the use of mercury in this sector is banned by the regulation on Control of Waste Electronic Equipment in Turkey (MoEU, 2012b). According to personal communications from the leading companies of the sector it is concluded that use of mercury has been phased out from the sector because of the regulation.

There is not any battery production facility in the borders of Turkey. The need for batteries is met by importing. Therefore, production of batteries with mercury is not considered as a source (Turkish Portable Battery Manufacturers and Importers Association, 2012).

Moreover, the use mercury is not used for the production of manometers and gauges in the borders of Turkey because of the restrictions on the supply of mercury. Since there is no mercury extraction in Turkey and import is very controlled and limited, required manometers and gauges with mercury are preferred to be imported.

The use of pesticides and biocides containing mercury is banned in Turkey under the Maximum Residue Limits of Pesticides Regulation (MoFAL, 2013). 
Table 16: Sub-Categories covered under Intentional Use of Mercury in Industrial Processes and Consumer Products

\begin{tabular}{|c|c|}
\hline Production of chemicals & Existence \\
\hline Chlor-alkali production with mercury-cells & No \\
\hline VCM production with mercury catalyst & No \\
\hline Acetaldehyde production with mercury catalyst & No \\
\hline \multicolumn{2}{|l|}{ Production of products with mercury content } \\
\hline $\mathrm{Hg}$ thermometers (medical, air, lab, industrial etc.) & Yes \\
\hline Electrical switches and relays with mercury & No \\
\hline Light sources with mercury (fluorescent, compact, others: see guideline) & Yes \\
\hline Batteries with mercury & No \\
\hline Manometers and gauges with mercury & No \\
\hline Biocides and pesticides with mercury & No \\
\hline Paints with mercury & No \\
\hline Skin lightening creams and soaps with mercury chemicals & No \\
\hline \multicolumn{2}{|l|}{ Consumption of products with mercury content } \\
\hline Dental amalgam fillings & Yes \\
\hline Thermometers & Yes \\
\hline Electrical switches and relays with mercury & Yes \\
\hline Light sources with mercury & Yes \\
\hline \multicolumn{2}{|l|}{ Batteries with mercury } \\
\hline Polyurethane (PU, PUR) produced with mercury catalyst & No \\
\hline Paints with mercury preservatives & No \\
\hline Skin lightening creams and soaps with mercury chemicals & No \\
\hline Medical blood pressure gauges (mercury sphygmomanometers) & Yes \\
\hline Other manometers and gauges with mercury & Yes \\
\hline Laboratory chemicals & Yes \\
\hline Other laboratory and medical equipment with mercury & No \\
\hline
\end{tabular}


The supply and use of paints with mercury is also banned under the Regulation on Restriction of Production, Market Supply and Use of Certain Hazardous Substances and Goods (MoEU, 2008).

The production and use of skin lightening creams and soaps with mercury chemicals are not considered as sources for this study because mercury is defined among the chemicals which are not allowed to be used in cosmetics by the Regulation on Cosmetics, except their limited use in Thiomersal (INN) and Phenylmercuric salts which are preservatives used in eye make-up products $(\mathrm{MoH}, 2005)$.

Since polyurethane (PU, PUR) is not produced with mercury catalyst in Turkey, its consumption is not considered as a remarkable source for Turkey. According to the Regulation on Medical Devices (MoH, 2007) supply of medical devices containing mercury was forbidden. Therefore, consumption of these kinds of devices is not considered as a source for the mercury releases in Turkey.

\subsubsection{Production and Consumption of $\mathrm{Hg}$ Thermometers}

Thermometers are the instruments that are used for temperature measurement. There are different types of thermometers on the market and being used in different areas like household, laboratories, industries and medical facilities. Mercury has been used in thermometers because of its physical property of expanding and contracting with temperature change (EC, 2013).

Mercury releases can occur both during the production and use of mercury containing thermometers. During the production process, mostly in the mercury filling step, some mercury vapor can be lost to the atmosphere. In addition to that other emissions can happen due to mercury spills, broken thermometers and accidents during the production. Since mercury is sealed in the thermometers, mercury releases do not occur during their use unless they break or crack. If they are broken, mercury is released to different compartments like air, water and land (UNEP-CB, 2013b). 
Even if mercury containing thermometers has been phased out and offered to be substituted by Turkish Ministry of Health, it is known that there are few facilities producing thermometers with stocked mercury for industrial use only and there are still some mercury containing thermometers on the market, however, mercury thermometers for medical use are not produced any more.

\section{Production}

Based on the information gathered from personal communications with the facility producing industrial thermometers, amount of industrial mercury thermometers produced per year in Turkey is assumed as 600 items. However, it should be noted that production of mercury containing thermometers has been phased out and planned to be stopped when the mercury stocks of facilities are run out.

It is known that there is only industrial thermometer production in Turkey. The range for mercury input factor for the industrial thermometers defined by UNEP is given in Table 17. For the determination of mercury releases from this source, mercury input factor of $10 \mathrm{~g} \mathrm{Hg} /$ item is chosen among the range since it is given for European Union (UNEP-CB, 2013b).

Table 17: Mercury content of industrial thermometers (UNEP-CB, 2013b)

\begin{tabular}{|l|c|}
\hline \multicolumn{1}{|c|}{ Material } & \multicolumn{1}{|c|}{$\begin{array}{c}\text { Input factor } \\
\text { (g mercury/item) }\end{array}$} \\
\hline $\begin{array}{l}\text { Industrial and special application } \\
\text { thermometers }\end{array}$ & $5-200$ \\
\hline
\end{tabular}

For the calculation of mercury input estimates from production of mercury containing thermometers, amount of items produced in a year is multiplied with the average mercury content in thermometers as follows; 


$$
600 \frac{\text { items }}{y} \times 10 \frac{\mathrm{g} \mathrm{Hg}}{\text { item }}=6 \frac{\mathrm{kg}}{\mathrm{y}}
$$

Output release estimates are calculated by using the output distribution factors given by the toolkit. Estimated mercury input value is multiplied with given distribution factors to estimate the releases as follows;

$$
\begin{gathered}
6 \frac{\mathrm{kg}}{\mathrm{y}} \times 0.01=0.1 \frac{\mathrm{kg}}{\mathrm{y}} \text { air releases } \\
6 \frac{\mathrm{kg}}{\mathrm{y}} \times 0.005=0.03 \frac{\mathrm{kg}}{\mathrm{y}} \text { water releases } \\
6 \frac{\mathrm{kg}}{\mathrm{y}} \times 0.1=0.6 \frac{\mathrm{kg}}{\mathrm{y}} \text { land releases } \\
6 \frac{\mathrm{kg}}{\mathrm{y}} \times 0.1=0.6 \frac{\mathrm{kg}}{\mathrm{y}} \text { general waste } \\
6 \frac{\mathrm{kg}}{\mathrm{y}} \times 0.01=0.1 \frac{\mathrm{kg}}{\mathrm{y}} \text { sector specific treatment/disposal }
\end{gathered}
$$

Use

Mercury releases may occur during the use of mercury thermometers. Since mercury concentration in a thermometer may differ a lot depending on its type, for a better estimation, thermometers sold in Turkey are grouped in three (UNEP-CB, 2013a). One of them is Medical Thermometers. Since they are forbidden by the Turkish Ministry of Health, this source is eliminated for the calculation of mercury release estimates. Other types are Glass Thermometers (air, laboratory, dairy etc.) and Engine Control Hg Thermometers/Large Industrial Hg Thermometers. Ranges of the input factors for these types of thermometers defined by UNEP are given in Table 18. Medium values of the ranges are used for the calculation of mercury input, except industrial thermometers. As it is mentioned before, mercury content of 
industrial thermometers is accepted as $10 \mathrm{~g} \mathrm{Hg} / \mathrm{item}$. It is assumed that $50 \%$ of Glass thermometers are consisted of ambient air temperature thermometers while $50 \%$ of it is consisted of other glass thermometers. Thus, calculation of estimates is done according to this assumption.

Table 18: Mercury content of thermometers (UNEP-CB, 2013b)

\begin{tabular}{|l|c|}
\hline \multicolumn{1}{|c|}{ Material } & $\begin{array}{c}\text { Input factor } \\
\text { (g mercury/item) }\end{array}$ \\
\hline Medical Thermometers & $0.5-1.5$ \\
\hline Ambient air temperature thermometer & $2-5$ \\
\hline Industrial thermometers & $5-200$ \\
\hline Other glass thermometers & $1-40$ \\
\hline
\end{tabular}

For the estimation of these releases, amount of mercury thermometers sold in a year is required. Since there is not mercury thermometer production in Turkey, whole thermometers which are on the market are assumed to be imported. Import values were collected from Import- Export database of Turkish Ministry of Economics and it is assumed that all imported thermometers will be sold and consumed ultimately. Amounts of mercury thermometers imported yearly to Turkey are found from the database for the years 2008-2012. Since the values have a fluctuating trend, the average amount of yearly imported $\mathrm{Hg}$ thermometers for the years 2008-2012 are taken for better estimate as 119457 items/ year. For the calculation, it is estimated that $50 \%$ of this value is in the glass thermometers category, while $50 \%$ of it is in Engine Control Hg Thermometers/Large Industrial Hg Thermometers category. In order to calculate mercury releases due to use of mercury thermometers, the amount produced in Turkey is added to the industrial thermometers group. Therefore, it is estimated that 59728 Glass Thermometers and 60329 Industrial Thermometers are sold in Turkey in a year. Input estimates are calculated from the use of $\mathrm{Hg}$ thermometers are calculated as; 


$$
\begin{gathered}
60329 \frac{\text { items }}{y} \times 10 \frac{\mathrm{g} \mathrm{Hg}}{\text { item }}=603 \frac{\mathrm{kg}}{\mathrm{y}} \text { from industrial thermometer use } \\
\left(\left(29864 \frac{\text { items }}{y} \times 3.5 \frac{\mathrm{g} \mathrm{Hg}}{\text { item }}\right)+\left(29864 \frac{\text { items }}{\mathrm{y}} \times 20.5 \frac{\mathrm{g} \mathrm{Hg}}{\text { item }}\right)\right) \\
=717 \frac{\mathrm{kg}}{\mathrm{y}} \text { from glass thermometer use }
\end{gathered}
$$

Total $\mathrm{Hg}$ input from two different $\mathrm{Hg}$ thermometer use is $1319 \mathrm{Kg} \mathrm{Hg} /$ year. Input value is distributed to different compartments as the releases by using the output distribution factors. While using the output distribution factors "no or very limited separate thermometer collection and all or most general waste is collected and handled in a publicly controlled manner" is assumed. Output mercury releases to different environmental compartments as a use of $\mathrm{Hg}$ thermometers are calculated as;

$$
\begin{gathered}
1319 \frac{\mathrm{kg}}{\mathrm{y}} \times 0.1=131.9 \frac{\mathrm{kg}}{\mathrm{y}} \text { air releases } \\
1319 \frac{\mathrm{kg}}{\mathrm{y}} \times 0.3=395.7 \frac{\mathrm{kg}}{\mathrm{y}} \text { water releases } \\
1319 \frac{\mathrm{kg}}{\mathrm{y}} \times 0.6=791.6 \frac{\mathrm{kg}}{\mathrm{y}} \text { general waste }
\end{gathered}
$$

\subsubsection{Production and Use of Light Sources with Mercury}

All types of fluorescent lamps contain small amounts of mercury as an essential component and there is not any alternative energy saving lighting devices like fluorescent lamps (EC, 2012). Mercury is introduced into the tube to produce UV light by passing the electrical current through the tube (UNEP-CB, 2013b). Mercury releases can happen during the production of lamps as well as their use. During the production of lamps small amounts of mercury can be lost to the environment. 
Likewise, breakage of lamps during their use can result in mercury releases to environment (UNEP-CB, 2013b).

\section{Production}

Production amount of fluorescent lamps in Turkey is gathered from Industrial Database of TUoCCE. Production amount of discharge lamps including high pressure mercury lamp, high pressure sodium lamp and metal halide lamp is found as 15530000 items/ year in total and UV light production is found as 390925 items/ year. Chosen input factors for fluorescent lamps from the ranges defined by UNEP are shown in Table 19. Input factor is decided to be taken as $30 \mathrm{mg} \mathrm{Hg} /$ item based on the given values in Table 19 for the calculation of input value from the production of discharge lamps and for the calculation of releases from UV light production, input factor is taken as $25 \mathrm{mg} \mathrm{Hg} /$ item. Amount of mercury input from this source is estimated as follows;

$$
\begin{gathered}
15530000 \frac{\text { items }}{y} \times 30 \frac{\mathrm{mg} \mathrm{Hg}}{\text { item }}=466 \frac{\mathrm{kg}}{\mathrm{y}} \text { from discharge lamps } \\
390925 \frac{\text { items }}{y} \times 25 \frac{\mathrm{mg} \mathrm{Hg}}{\text { item }}=10 \frac{\mathrm{kg}}{\mathrm{y}} \text { from UV lights }
\end{gathered}
$$

Table 19: Input factors for light sources (UNEP-CB, 2013b)

\begin{tabular}{|l|c|}
\hline \multicolumn{1}{|c|}{ Material } & \multicolumn{1}{|c|}{$\begin{array}{c}\text { Input factor } \\
\text { (mg mercury/item) }\end{array}$} \\
\hline High pressure mercury lamp & 30 \\
\hline High pressure sodium lamp & 30 \\
\hline Metal halide lamp & 25 \\
\hline UV light for tanning & 25 \\
\hline Florescent tubes (double end) & 25 \\
\hline Compact florescent lamp (CFL single end) & 10 \\
\hline
\end{tabular}


Calculated input value, which is $476 \mathrm{~kg} / \mathrm{y}$ in total, is distributed according to the default output distribution factors and the results are found as;

$$
\begin{gathered}
476 \frac{\mathrm{kg}}{\mathrm{y}} \times 0.01=4.8 \frac{\mathrm{kg}}{\mathrm{y}} \text { air releases } \\
476 \frac{\mathrm{kg}}{\mathrm{y}} \times 0.005=2.4 \frac{\mathrm{kg}}{\mathrm{y}} \text { water releases } \\
476 \frac{\mathrm{kg}}{\mathrm{y}} \times 0.1=47.6 \frac{\mathrm{kg}}{\mathrm{y}} \text { land releases } \\
476 \frac{\mathrm{kg}}{\mathrm{y}} \times 0.1=47.6 \frac{\mathrm{kg}}{\mathrm{y}} \text { general waste } \\
476 \frac{\mathrm{kg}}{\mathrm{y}} \times 0.01=4.8 \frac{\mathrm{kg}}{\mathrm{y}} \text { sector specific treatment/disposal }
\end{gathered}
$$

Use

Different types of lamps contain different amount of mercury. For more precise mercury release estimation from the use of mercury containing lamps, they are evaluated under three main groups as fluorescent tubes (double end), compact fluorescent lamp (CFL) and other $\mathrm{Hg}$ containing light sources. Other $\mathrm{Hg}$ containing light sources group is assumed to be consisted of equally between High-pressure sodium lamps, UV light and Metal halide lamps (UNEP-CB, 2013a). For the calculation of estimated mercury release from this activity input factors given in Table 19 are used.

While estimating the amount of light sources with mercury consumed in Turkey for a year, amount of lights produced in Turkey is summed up with the amount imported and the exported amount is subtracted from this value. Import and export amounts are gathered from Import-Export Database of Turkish Ministry of Economics. 
According to data collected it is assumed that 35 million fluorescent tubes with double end, 85 million compact florescent lamps (CFLs) and 27 million other $\mathrm{Hg}$ containing lamps are consumed in Turkey as the average of years 2008-2012. Mercury input estimate from this source is calculated by multiplying consumption rates with the chosen default input factors as follows;

$$
\begin{gathered}
35000000 \frac{\text { items }}{y} \times 25 \frac{\mathrm{mg} \mathrm{Hg}}{\text { item }}=875 \frac{\mathrm{kg}}{\mathrm{y}} \text { from fluorescent tubes } \\
85000000 \frac{\text { items }}{y} \times 10 \frac{\mathrm{mg} \mathrm{Hg}}{\text { item }}=850 \frac{\mathrm{kg}}{\mathrm{y}} \text { from compact fluorescent lamps } \\
\left(9000000 \frac{\text { items }}{y} \times 30 \frac{\mathrm{mg} \mathrm{Hg}}{\text { item }}\right)+\left(9000000 \frac{\text { items }}{\mathrm{y}} \times 25 \frac{\mathrm{mg} \mathrm{Hg}}{\text { item }}\right) \\
+\left(9000000 \frac{\text { items }}{\mathrm{y}} \times 25 \frac{\mathrm{mg} \mathrm{Hg}}{\text { item }}\right) \\
=720 \frac{\mathrm{kg}}{\mathrm{y}} \text { from other } \mathrm{Hg} \text { containing lamps }
\end{gathered}
$$

Calculated total input value which is $2445 \mathrm{~kg} \mathrm{Hg} / \mathrm{y}$ is distributed as output releases to the environment. While using given distribution factors, "no or very limited separate lamps collection and all or most general waste is collected and handled in a publicly controlled manner". Estimated output releases are;

$$
\begin{gathered}
2445 \frac{\mathrm{kg}}{y} \times 0.05=122.3 \frac{\mathrm{kg}}{\mathrm{y}} \text { air releases } \\
2445 \frac{\mathrm{kg}}{\mathrm{y}} \times 0.95=2322.8 \frac{\mathrm{kg}}{\mathrm{y}} \text { general waste }
\end{gathered}
$$

\subsubsection{Production and Use of Batteries with Mercury}

Mercury is used in different types of batteries and it is one of the best known uses of mercury in products. It is mainly used in primary batteries which are non- 
rechargeable. Mercury is used in mercury oxide (zinc-mercury) batteries in high concentrations like 30-32\% and mercury oxide acts as the positive electrode in the battery. In addition to these types, button shape batteries of alkaline, silver oxide and zinc/air types may contain some amounts of mercury. Other types of batteries are not assumed to contain any mercury (UNEP-CB, 2013b).

Mercury releases may occur from the production and use of batteries containing mercury. However, since there is not domestic battery production in Turkey, production of batteries is not taken as a source in this study. On the other hand, during the use of batteries with mercury, some releases to environment may occur depending on the general waste management system of the country and existence and of battery collection schemes. Usually, separately collected batteries are dispose in a safer manner, otherwise it can end up with the release of mercury in the battery to air, water and land according to its disposal type and collection ratio.

Different types of batteries contain different amounts of mercury. For better estimation, batteries are grouped as mercury oxide (mercury zinc cells), other button cells and other batteries with mercury (UNEP-CB, 2013a). Mercury contents of the batteries are shown in Table 20. Defined mercury contents are used for the calculation of mercury input from the use of batteries with mercury (UNEP-CB, 2013b).

While estimating the amount of batteries with mercury consumed in Turkey for a year, amount of batteries exported is subtracted from the amount imported. Import and export amounts are gathered from Import-Export Database of Turkish Ministry of Economics for the years 2006-2010, since there is not any available data after 2006. In order to make better mercury release estimation average amount of batteries imported and exported is used for the calculations. According to statistics, amount of mercury oxide batteries consumed in Turkey in a year is assumed as 1 ton and button cells as 47 tons, of which 23 tons are alkaline button, 9 tons are silver oxide button and 17 tons are zinc-air button cells. Since use of mercury in other types of batteries 
is limited, its import and export are also stopped and it is accepted as a non-valid source for Turkey.

Table 20: Default mercury content of batteries (UNEP-CB, 2013b)

\begin{tabular}{|l|c|}
\hline \multicolumn{1}{|c|}{ Battery type } & $\begin{array}{c}\text { Input factor } \\
\text { (kg mercury/ton battery) }\end{array}$ \\
\hline Mercury oxide (mercury-zinc cells) & 320 \\
\hline Zinc-air button cells & 12 \\
\hline Alkaline button cells & 5 \\
\hline Silver oxide button cells & 4 \\
\hline Alkaline, other than button cell shapes & 0.25 \\
\hline
\end{tabular}

Mercury input from the consumption of mercury oxide batteries and button cell batteries are calculated by multiplying the mercury concentrations of batteries with the amount of batteries consumed in Turkey in a year as follows;

$$
\begin{gathered}
1 \frac{\text { ton }}{y} \times 320 \frac{\mathrm{kg} \mathrm{Hg}}{\text { ton }}=320 \frac{\mathrm{kg}}{\mathrm{y}} \text { from mercury oxide batteries } \\
\left(23 \frac{\text { tons }}{\mathrm{y}} \times 5 \frac{\mathrm{kg} \mathrm{Hg}}{\mathrm{ton}}\right)+\left(9 \frac{\text { tons }}{\mathrm{y}} \times 4 \frac{\mathrm{kg} \mathrm{Hg}}{\mathrm{ton}}\right)+\left(17 \frac{\text { tons }}{\mathrm{y}} \times 12 \frac{\mathrm{kg} \mathrm{Hg}}{\mathrm{ton}}\right) \\
=355 \frac{\mathrm{kg}}{\mathrm{y}} \text { from button cell batteries }
\end{gathered}
$$

Output distribution of mercury releases from mercury battery use is highly depended on the general waste management strategy of the country. When Turkey's situation on the collection and recycling of batteries is considered, it is very hard to say that high rates of battery collection are achieved. There for the calculation of release estimates, "no or very limited separate battery collection is and all or most general waste collection in publicly controlled manner" is assumed to be on the safe side (UNEP-CB, 2013b). 
Mercury release from the use of batteries with mercury to the environment is calculated as by multiplying the total mercury input from use of different types of mercury batteries with the assumed output distribution factor as $675 \mathrm{~kg} / \mathrm{year}$ in general waste.

$$
675 \frac{\mathrm{kg}}{\mathrm{y}} \times 1=675 \frac{\mathrm{kg}}{\mathrm{y}} \text { general waste }
$$

\subsubsection{Production and Use of Electrical Switches and Relays with Mercury}

Mercury is used in various types of switches and relays. Switches are used to regulate electricity flow and relays are the electrically controlled switches. Switches with mercury control electricity according to changes in pressure and temperature (EC, 2010).

Mercury releases may occur during the production of switches and relays as well as during use. The use of mercury in electronic equipment including switches has been controlled by the Regulation on Control of Waste Electronic Equipment since 2009. Even if their use is controlled in electronic equipment produced, due to long service life of these items mercury switches and relays will be present in wastes (UNEP-CB, 2013b).

Table 21: Input factor range for mercury use in switches, contacts and relays (UNEPCB, 2013b)

\begin{tabular}{|l|c|}
\hline & \multicolumn{1}{|c|}{$\begin{array}{c}\text { Input factor } \\
\text { (g mercury/person.year) }\end{array}$} \\
\hline $\begin{array}{l}\text { Mercury consumed annually with mercury } \\
\text { switches and relays }\end{array}$ & $0.02-0.25$ \\
\hline
\end{tabular}

The range for the amount of mercury consumed annually with switches and relays per inhabitant is shown in Table 21. In this study, for the calculation of mercury 
input from this activity input factor is chosen as $0.07 \mathrm{~g} /$ person.year different from the default value given in the toolkit considering to Turkey's situation.

For the calculation of mercury input estimates from that use, number of people living in Turkey, which is 72698000 (UNEP-CB, 2012), is multiplied with the accepted input factor. While estimating the mercury input, $100 \%$ electrification rate helping to show the access of population to electricity for better estimate is used. Mercury input is calculated as follows;

$$
72698000 \text { inhabitants } x 0.07 \frac{\mathrm{g} \mathrm{Hg}}{\text { inhabitant.year }}=5088 \frac{\mathrm{kg} \mathrm{Hg}}{y}
$$

Output releases from the use of switches and relays with mercury are estimated by assuming "no or very limited separate switches collection and all or most general waste is collected and handled in a publicly controlled manner". Output release estimates are calculated as;

$$
\begin{gathered}
5088 \frac{\mathrm{kg}}{\mathrm{y}} \times 0.1=508.8 \frac{\mathrm{kg}}{\mathrm{y}} \text { air releases } \\
5088 \frac{\mathrm{kg}}{\mathrm{y}} \times 0.1=508.8 \frac{\mathrm{kg}}{\mathrm{y}} \text { land releases } \\
5088 \frac{\mathrm{kg}}{\mathrm{y}} \times 0.8=4070.4 \frac{\mathrm{kg}}{\mathrm{y}} \text { general waste }
\end{gathered}
$$

\subsubsection{Use of Dental Amalgam Fillings}

Dental amalgam fillings consist of the mixture of mercury, silver, copper and tin. During the production, preparation of amalgam fillings, use and disposal, mercury can be released to air, water and land. In this study, mercury releases from dental amalgam fillings are evaluated during their life-cycle phase. In addition to that 
releases may occur at the end of life of a person having fillings. However, this source will be covered in Section 5.4.

Mercury content of dental amalgam filling varies within the range given in Table 22. For the estimation of mercury input from the dental amalgam fillings, Danish situation where mercury fillings had to be used widely and now still be used to some degree are taken as a reference point. For the calculation of mercury input, recommended input factor which is $0.2 \mathrm{~g} \mathrm{Hg} /$ person per year is multiplied with the factor describing the access to dental care in terms of dental personnel density in the country and then divided by the Denmark's personnel density factor (UNEP-CB, 2013b). Input mercury release is calculated as follows;

72698000 inhabitants $x 0.2 \frac{\mathrm{g} \mathrm{Hg}}{\text { inhabitant.year }} \times \frac{0.241}{0.829}=4226 \frac{\mathrm{kg} \mathrm{Hg}}{\mathrm{y}}$

Table 22: Mercury used during the preparation of dental amalgam fillings (UNEP-

CB, 2013b)

\begin{tabular}{|l|c|}
\hline & \multicolumn{1}{|c|}{$\begin{array}{c}\text { Input factor } \\
\text { (g mercury/person.year) }\end{array}$} \\
\hline $\begin{array}{l}\text { Mercury used annually for dental amalgam } \\
\text { preparations }\end{array}$ & $0.05-0.2$ \\
\hline
\end{tabular}

Output mercury releases from the use of mercury fillings are estimated considering whole life phases of a filling. Output distribution factors are shown in Table 23. It can be seen from the table that $40 \%$ of the $\mathrm{Hg}$ supply is lost during the preparation of fillings while $60 \%$ of it ends up in mounted fillings. The part of the mercury in the mounted fillings is distributed as environmental releases according to given output distribution factors in Table 23 during use and disposal phases. While estimating output releases from the disposal phase "country where only dental chair filters/strainers are used in most clinics" is assumed. 
Table 23: Default mercury output distribution factors for dental amalgam fillings

(UNEP-CB, 2013b)

\begin{tabular}{|l|c|c|c|c|c|}
\hline \multicolumn{1}{|c|}{ Phase in Life-Cycle } & Air & Water & Products & $\begin{array}{c}\text { General } \\
\text { Waste }\end{array}$ & $\begin{array}{c}\text { Sector specific } \\
\text { treatment/disposal }\end{array}$ \\
\hline $\begin{array}{l}\text { Preparations of fillings } \\
\text { at dentist clinics }\end{array}$ & 0.02 & 0.14 & 0.6 & 0.12 & 0.12 \\
\hline $\begin{array}{l}\text { Use- from fillings in } \\
\text { the mouth }\end{array}$ & 0.02 & & & \\
\hline Disposal & & 0.3 & 0.06 & 0.12 & 0.12 \\
\hline
\end{tabular}

Estimated mercury releases from the preparation, use and disposal of amalgam fillings with mercury are calculated as follows;

$4226 \frac{\mathrm{kg}}{\mathrm{y}} \times 0.02=84.5 \frac{\mathrm{kg}}{\mathrm{y}}$ air releases

$4226 \frac{\mathrm{kg}}{\mathrm{y}} \times 0.14=591.6 \frac{\mathrm{kg}}{\mathrm{y}}$ water releases

$4226 \frac{\mathrm{kg}}{\mathrm{y}} \times 0.12=507.1 \frac{\mathrm{kg}}{\mathrm{y}}$ general waste

$4226 \frac{\mathrm{kg}}{\mathrm{y}} \times 0.12=507.1 \frac{\mathrm{kg}}{\mathrm{y}}$ sector specific treatment $/$ disposal

$4226 \frac{\mathrm{kg}}{\mathrm{y}} \times 0.6=2535.6 \frac{\mathrm{kg}}{\mathrm{y}}$ in product (as mounted fillings)

$2535.6 \frac{\mathrm{kg}}{\mathrm{y}} \times 0.02=50.7 \frac{\mathrm{kg}}{\mathrm{y}}$ water releases from use

$2535.6 \frac{\mathrm{kg}}{\mathrm{y}} \times 0.3=760.7 \frac{\mathrm{kg}}{\mathrm{y}}$ water releases from disposal 
$2535.6 \frac{\mathrm{kg}}{\mathrm{y}} \times 0.06=152.1 \frac{\mathrm{kg}}{\mathrm{y}}$ by product and impurities from disposal $2535.6 \frac{\mathrm{kg}}{\mathrm{y}} \times 0.12=304.3 \frac{\mathrm{kg}}{\mathrm{y}}$ general waste from disposal

$2535.6 \frac{\mathrm{kg}}{\mathrm{y}} \times 0.12=304.3 \frac{\mathrm{kg}}{\mathrm{y}}$ sector specific treatment from disposal

\subsubsection{Other Use of Mercury in Products}

Within the context of this part, use of mercury in manometers and gauges and laboratory chemicals are covered.

Mercury is used in medical blood pressure gauges and widely used in clinics because of its consistent results. There is no production of these kinds of gauges in the borders of Turkey but the need is met by import. For the calculation of mercury input from the use of medical blood gauges with mercury, default mercury content of 80 $\mathrm{g} /$ person.year item is chosen as mercury input factor as it can be seen in Table 24 .

Table 24: Mercury input factor range for medical blood pressure gauges (UNEP-CB, 2013b)

\begin{tabular}{|l|c|}
\hline & $\begin{array}{c}\text { Input factor } \\
\text { (g mercury/item) }\end{array}$ \\
\hline Medical blood pressure gauges & $70-85$ \\
\hline
\end{tabular}

Amount of medical blood pressure gauges consumed is assumed according to personnel communications with the purchasing office of the hospitals. It is seen that a hospital plans to buy a medical blood pressure gauges with mercury in an average of6 years. According to Turkish Statics Institute for the year 2012, there are 29960 health care organizations. Therefore, mercury input from this activity is calculated as; 


$$
29960 \times \frac{1 \text { item }}{6 \text { years }} \times 80 \frac{\mathrm{g} \mathrm{Hg}}{\text { item }}=400 \frac{\mathrm{kg} \mathrm{Hg}}{\mathrm{y}}
$$

Mercury output releases are calculated by using the distribution factors as follow;

$$
\begin{gathered}
400 \frac{\mathrm{kg}}{\mathrm{y}} \times 0.1=40 \frac{\mathrm{kg}}{\mathrm{y}} \text { air releases } \\
400 \frac{\mathrm{kg}}{\mathrm{y}} \times 0.3=120 \frac{\mathrm{kg}}{\mathrm{y}} \text { water releases } \\
400 \frac{\mathrm{kg}}{y} \times 0.6=240 \frac{\mathrm{kg}}{\mathrm{y}} \text { general waste }
\end{gathered}
$$

In addition to medical blood pressure gauges, mercury is used in manometer and gauges which are used with industrial and meteorological purposes. Like other products containing mercury, mercury releases can happen from the production, use and disposal. Usually, manometers and gauges are provided with mercury, thus in this study only use and disposal phases are considered as the sources for mercury releases.

For the calculation of mercury input from the use of manometers and gauges, default mercury content of $0.005 \mathrm{~g}$ /inhabitant (UNEP-CB, 2013b) is used. The number of inhabitants which is 72698000 (UNEP-CB, 2012) is multiplied with decided input factor by assuming $100 \%$ electrification rate helping to show the access of population to electricity. Mercury input from is calculated as;

$$
72698000 \text { inhabitants } x 0.005 \frac{\mathrm{g} \mathrm{Hg}}{\text { inhabitant }}=363 \frac{\mathrm{kg} \mathrm{Hg}}{\mathrm{y}}
$$

Mercury release estimates are calculated by using the same output distribution factors used for medical blood gauges. Estimated mercury releases are; 


$$
\begin{gathered}
363 \frac{\mathrm{kg}}{\mathrm{y}} \times 0.1=36.3 \frac{\mathrm{kg}}{\mathrm{y}} \text { air releases } \\
363 \frac{\mathrm{kg}}{\mathrm{y}} \times 0.3=108.9 \frac{\mathrm{kg}}{\mathrm{y}} \text { water releases } \\
363 \frac{\mathrm{kg}}{\mathrm{y}} \times 0.6=217.9 \frac{\mathrm{kg}}{\mathrm{y}} \text { general waste }
\end{gathered}
$$

Mercury is used in laboratories with different purposes like in instruments, or reagents, preservatives and catalysts. It can be released to air through lab ventilation and to water and land through wastewater ways and disposal (UNEP-CB, 2013b). While estimating mercury inputs, reported use of mercury in laboratories in European Union is taken as a reference point. Default input factor of $0.01 \mathrm{~g}$ Hg/inhabitant (UNEP-CB, 2013a) is used and Turkey's population of 72698000 (UNEP-CB, 2012) is used for the calculation of mercury estimate. While estimating mercury input, calculated value is reduced with the factor of 1 which is $100 \%$ electrification rate helping to show the access of population to electricity. Mercury input is calculated as;

$$
72698000 \text { inhabitants } x 0.01 \frac{\mathrm{g} \mathrm{Hg}}{\text { inhabitant }}=726 \frac{\mathrm{kg} \mathrm{Hg}}{y}
$$

Since there is not any available data related with the output distribution of mercury releases from the activity, equal distribution between water, general waste and sector specific waste treatment/disposal is assumed (UNEP-CB, 2013a). Output mercury releases are estimated as;

$$
726 \frac{\mathrm{kg}}{\mathrm{y}} \times 0.333=242 \frac{\mathrm{kg}}{\mathrm{y}}
$$

water releases, general waste and sector specific treatment/disposal 


\subsection{Crematoria and Cemeteries}

In this section, mercury releases related to cremation and burial of human bodies are studied. The main sources for the estimated releases are mainly the mercury in dental amalgam fillings and minor concentrations of mercury in human body. When the human bodies are buried, mercury is released to soil. During the cremation mercury is released to the atmosphere with the flue gas (UNEP-CB, 2013a).

Cremation is not applied in Turkey because of the religion. Therefore, it is not considered as a source for the mercury releases in Turkey. Number of corpse buried and average amount of mercury contained in each corpse are required for the calculation of mercury input from the cemeteries. Best release estimate can be done with the use of national data on grams of mercury per corpse buried. Since there is no information available about this, the interval for the amount of mercury in human bodies buried given in Table 25 is offered to be used to make a rough first estimate. The medium value of the given interval which is $2.5 \mathrm{~g} \mathrm{Hg} /$ corpse is used for the estimation of mercury releases from this source (UNEP-CB, 2013b).

Table 25: Mercury input factor range for cemeteries (UNEP-CB, 2013b)

\begin{tabular}{|c|c|}
\hline Source & $\begin{array}{c}\text { Input factor } \\
\text { (g mercury/corpse) }\end{array}$ \\
\hline Burial & $1-4$ \\
\hline
\end{tabular}

The average number of corpse buried in last 5 years is gathered from Turkish Statistical Institute's database death statistics, assuming all death bodies are buried, as 375000 persons/ year (TSI, 2013a). Mercury input is calculated as by multiplying the average death number in Turkey in a year with the given input factor as follows;

$$
375000 \frac{\text { persons }}{\text { year }} \times 2.5 \frac{\mathrm{g} \mathrm{Hg}}{\text { corpse }}=937.5 \frac{\mathrm{kg} \mathrm{Hg}}{y}
$$


Since all the mercury in human body is assumed to be released to soil in cemeteries, calculated mercury input estimate from the cemeteries is assumed to be turned into releases to land (UNEP-CB, 2013b). Therefore, it can be concluded $937.5 \mathrm{~kg}$ $\mathrm{Hg} /$ year is estimated as releases to land.

\subsection{General Waste Management}

In this section, sources related to general waste management contributing to mercury amounts in the environment are studied to determine mercury release estimates to different environmental compartments. Within the context of the section, waste incineration, waste deposition/landfilling and waste water treatment activities in Turkey are evaluated. The amount of mercury released to the environment from waste and wastewaters may change depending on the waste management strategy of the country. To determine the situation in Turkey, sub-categories related to general waste management taken into consideration are given in Table 26. First of all, the existence of given sub-categories are investigated. Except "Incineration of municipal/general waste" category, all the sub-categories are considered as valid sources for this study according to waste management system applied in Turkey.

Table 26: Sub-Categories covered under General Waste Management

\begin{tabular}{|l|c|}
\hline Waste incineration & Existence \\
\hline Incineration of municipal/general waste & No \\
\hline Incineration of hazardous waste & Yes \\
\hline Incineration and open burning of medical waste & Yes \\
\hline Sewage sludge incineration & Yes \\
\hline Open fire waste burning (on landfills and informally) & Yes \\
\hline Waste deposition/landfilling and waste water treatment & Yes \\
\hline Controlled landfills/deposits & Yes \\
\hline Informal dumping of general waste & Yes \\
\hline Waste water system/treatment & \\
\hline
\end{tabular}




\subsubsection{Incineration of Hazardous Waste}

Discarded products and some industrial wastes containing mercury are the major sources of the mercury in hazardous waste. Some of the hazardous waste is incinerated as a part of country's waste management. Mostly, incineration of hazardous waste can result in the release of mercury in waste to the atmosphere (UNEP-CB, 2013b).

Mercury content of waste can vary a lot depending on the content of the waste. The range for mercury content of hazardous waste is given in Table 27. Since there is no specific information about the mercury content of hazardous waste in Turkey, for the rough estimation of mercury input from the activity $24 \mathrm{~g} \mathrm{Hg}$ release per ton of hazardous waste incinerated, which is the medium value of the range given, is accepted as input factor.

Table 27: Mercury input factor range for medical waste (UNEP-CB, 2013b)

\begin{tabular}{|l|c|}
\hline \multicolumn{1}{|c|}{ Material } & $\begin{array}{c}\text { Input factor } \\
\text { (g mercury/ ton waste) }\end{array}$ \\
\hline Hazardous/Medical Waste & $8-40$ \\
\hline
\end{tabular}

Amount of hazardous waste incinerated is estimated by summing up the capacities of hazardous waste incineration facilities in Turkey and estimated as 42750 tons/year. Mercury input from the incineration of hazardous waste is calculated as;

$$
42750 \frac{\text { tons }}{\text { year }} \times 24 \frac{\mathrm{g} \mathrm{Hg}}{\text { ton }}=1026 \frac{\mathrm{kg} \mathrm{Hg}}{\text { year }}
$$

Estimated mercury input from this activity is distributed to different environmental compartments by using the output distribution factors given Table 28. Output distribution factors are given for incineration of municipal waste. However, in this study, due to the lack of output distribution factors for incineration of different types 
of wastes, the same factors with the assumption of "Particulate Matter Reduction with Simple ESP or similar" were used (UNEP-CB, 2013a).

Table 28: Output distribution factors for incineration of municipal waste with mercury content (UNEP-CB, 2013a)

\begin{tabular}{|c|c|c|}
\hline Source & Air & $\begin{array}{c}\text { Sector specific } \\
\text { treatment/disposal }\end{array}$ \\
\hline Incineration of waste & 0.9 & 0.1 \\
\hline
\end{tabular}

According to Table 28, output mercury release estimates are calculated as follows;

$$
\begin{gathered}
1026 \frac{\mathrm{kg} \mathrm{Hg}}{\text { year }} \times 0.9=923.4 \frac{\mathrm{kg} \mathrm{Hg}}{\text { year }} \text { air releases } \\
1026 \frac{\mathrm{kg} \mathrm{Hg}}{\text { year }} \times 0.1=102.6 \frac{\mathrm{kg} \mathrm{Hg}}{\text { year }} \text { sector specific treatment } / \text { disposal }
\end{gathered}
$$

\subsubsection{Incineration and Open Burning of Medical Waste}

Mercury in the medical waste is mostly originated from disposal of products with mercury and process waste (UNEP-CB, 2013b). There are facilities in which medical wastes are incinerated as a part of waste management or they are open burned. Like in the incineration of hazardous wastes, high portion of mercury in the waste is released to the atmosphere.

According to the content of medical waste incinerated, the amount of mercury releases may differ a lot. Since it is very hard to get data about the content of medical waste in Turkey, the medium value of the input factor range given in Table 27 which is $24 \mathrm{~g} \mathrm{Hg}$ per ton of waste incinerated is used to make rough mercury input estimate. Amount of medical waste incinerated in facilities Turkey for the year of 2010 is found as 17287 tons and the amount of medical waste open burned is found as 3408 tons in 2004 (TSI, 2013c). Since updated value of these numbers are not available at 
the time of study, the total amount of medical waste incinerated or open burned is accepted as 20695 tons per year in total. Mercury input from this activity for Turkey is calculated as;

$$
20695 \frac{\text { tons }}{\text { year }} \times 24 \frac{\mathrm{g} \mathrm{Hg}}{\text { ton }}=497 \frac{\mathrm{kg} \mathrm{Hg}}{\text { year }}
$$

For the calculation of mercury output from the incineration and open burning of medical wastes, estimated mercury input is multiplied with the factors given Table 28 with the same assumption. Output releases are estimated as;

$$
\begin{gathered}
497 \frac{\mathrm{kg} \mathrm{Hg}}{\text { year }} \times 0.9=447.3 \frac{\mathrm{kg} \mathrm{Hg}}{\text { year }} \text { air releases } \\
497 \frac{\mathrm{kg} \mathrm{Hg}}{\text { year }} \times 0.1=49.7 \frac{\mathrm{kg} \mathrm{Hg}}{\text { year }} \text { sector specific treatment } / \text { disposal }
\end{gathered}
$$

\subsubsection{Sewage Sludge Incineration}

The amount of mercury in sewage sludge depends on the amount in waste water. Depending on the type of waste water, mercury content of the sludge and sludge handling methods change. If hazardous substance content of the sludge is low, it can be used as a fertilizer, otherwise it is incinerated, landfilled or further treated to be minimized (UNEP-CB, 2013b).

For the calculation of mercury input, mercury input factor for the sewage sludge is accepted as $2 \mathrm{~g} \mathrm{Hg} /$ ton (UNEP-CB, 2013a). The amount of total sewage sludge incinerated in Turkey for the year 2011 is gathered as 8335 tons from Turkish Ministry of Environment and Urbanization (MoEU, 2012a). Mercury input from the sewage sludge incineration is calculated by multiplying the amount of sewage sludge incinerated in Turkey in a year with input factor as follows;

$$
8335 \frac{\text { tons }}{\text { year }} \times 2 \frac{\mathrm{g} \mathrm{Hg}}{\text { ton }}=17 \frac{\mathrm{kg} \mathrm{Hg}}{\text { year }}
$$


Output releases are calculated by using the output distribution factors given in Table 28 since there is not available output distribution factor for the incineration of sewage sludge (UNEP-CB, 2013a). Estimated output releases are found as follows;

$$
\begin{gathered}
17 \frac{\mathrm{kg} \mathrm{Hg}}{\text { year }} \times 0.9=15.3 \frac{\mathrm{kg} \mathrm{Hg}}{\text { year }} \text { air releases } \\
17 \frac{\mathrm{kg} \mathrm{Hg}}{\text { year }} \times 0.1=1.7 \frac{\mathrm{kg} \mathrm{Hg}}{\text { year }} \text { sector specific treatment/disposal }
\end{gathered}
$$

\subsubsection{Open Fire Waste Burning}

This sub-category covers informal incineration of waste in barrels, containers or bare land. This type of burning does not contain any air pollution control units and mercury in the waste is released to the environment during open fire.

Some portion of municipal waste is open fire burned in Turkey. Input factor of $5 \mathrm{~g}$ $\mathrm{Hg} / \mathrm{ton}$ of waste is used for the estimation of mercury input from this source (UNEPCB, 2013a). The amount of waste open fire burned in Turkey is gathered as 134000 for the year of 2010 (TSI, 2013c). Mercury input is calculated as follows;

$$
134000 \frac{\text { tons }}{\text { year }} \times 5 \frac{\mathrm{g} \mathrm{Hg}}{\text { ton }}=670 \frac{\mathrm{kg} \mathrm{Hg}}{\text { year }}
$$

It assumed that all mercury in the waste is released to the atmosphere. Therefore, mercury release estimates from the open fire waste burning is found $670 \mathrm{~kg} \mathrm{Hg} /$ year.

\subsubsection{Controlled Landfills/Deposits}

Controlled landfills/deposits are one of the sources of mercury releases to the environment because of the mercury in waste. Major sources of mercury in general waste are the discarded products with mercury, process waste, mercury naturally found in materials and mercury as anthropogenic pollutant in bulk materials (UNEP- 
$\mathrm{CB}, 2013 \mathrm{~b})$. Mercury in landfills is mostly released through the water formed which is known as leachate. If leachate is not collected separately and treated, it may reach to the ground and groundwater, causing environmental pollution. Likewise, some amount of mercury in waste is slowly released to the atmosphere by evaporation.

Table 29: Mercury input factor range for municipal waste (UNEP-CB, 2013b)

\begin{tabular}{|l|c|}
\hline \multicolumn{1}{|c|}{ Material } & $\begin{array}{c}\text { Input factor } \\
\text { (g mercury/ ton waste) }\end{array}$ \\
\hline General waste & $1-10$ \\
\hline
\end{tabular}

Amount of mercury released to the environment from landfills totally depends on the content of the waste landfilled and presence of protective lining and leachate treatment. Even if a general range for mercury content of municipal waste is given in Table 29, mercury content of the municipal waste may vary a lot between the countries, even regions. Using this as a starting point, in this study, during the formation of SFA of mercury, since landfilling is the intermediate step of mercury pathway, mercury content of the municipal waste in Turkey is calculated from the diagram with the aim of balancing. Calculations done are explained in Section 6.1.2 in detail.

\subsubsection{Informal Dumping of General Waste}

This sub-category covers waste dumping under informal conditions without taking any precautions to protect human health and the environment. As a result, mercury in the waste may be released to water, air and soil.

For the calculation of estimated mercury input from informal dumping of general waste, mercury input factor of $5 \mathrm{~g} \mathrm{Hg}$ / ton of waste which is the medium value of the range given in Table 29 is used (UNEP-CB, 2013a). The amount of general waste which is dumped informally to land, water and buried are gathered as around 200000 
tons of waste for 2010 (TSI, 2013c). Mercury input from this activity is calculated as;

$$
200000 \frac{\text { tons }}{\text { year }} \times 5 \frac{\mathrm{g} \mathrm{Hg}}{\text { ton }}=1000 \frac{\mathrm{kg} \mathrm{Hg}}{\text { year }}
$$

Since it is very hard to get information about how calculated mercury input is divided between different environmental compartments, default output distribution factors defined by UNEP (2013b) is used for the calculation of estimates. Mercury output estimates are calculated as follows;

$$
\begin{gathered}
1000 \frac{\mathrm{kg} \mathrm{Hg}}{\text { year }} x 0.1=100 \frac{\mathrm{kg} \mathrm{Hg}}{\text { year }} \text { air releases } \\
1000 \frac{\mathrm{kg} \mathrm{Hg}}{\text { year }} x 0.1=100 \frac{\mathrm{kg} \mathrm{Hg}}{y e a r} \text { water releases } \\
1000 \frac{\mathrm{kg} \mathrm{Hg}}{y e a r} x 0.8=800 \frac{\mathrm{kg} \mathrm{Hg}}{y e a r} \text { land releases }
\end{gathered}
$$

\subsubsection{Waste Water System/Treatment}

Waste water treatment systems are among the sources of mercury releases to the environment because of the mercury in wastewater. Mercury in wastewater mainly originates from the products and processes with mercury and atmospheric deposition. Mercury is released to water through treated effluent from WWTPs, land through the application of sewage sludge as fertilizer and air through sewage sludge incineration or application (UNEP-CB, 2013b).

Table 30: Mercury input factor range for municipal wastewater (UNEP-CB, 2013b)

\begin{tabular}{|l|c|}
\hline \multicolumn{1}{|c|}{ Material } & $\begin{array}{c}\text { Input factor } \\
\left(\mathbf{m g ~ m e r c u r y} / \mathbf{m}^{\mathbf{3}}\right)\end{array}$ \\
\hline Municipal waste water & $0.5-10$ \\
\hline
\end{tabular}


Mercury content of wastewater varies in the range given in Table 30. In this study, like in the case of landfills, mercury content of wastewaters in Turkey is found by using the SFA diagram formed for mercury. Estimated mercury releases are also calculated according to the mercury input value by using the default output distribution factors. Calculations done for the determination of mercury content of municipal wastewater and output releases from WWTPs are explained in section 6.1.1.

\subsection{Summary Table of Mercury Inventory}

In this section, possible sources of mercury releases to the environment and calculated mercury input and output releases which are estimated by using the Mercury Toolkit Level 1 developed by UNEP are summarized in Table 31. Used input factors and collected activity rate data for each source are presented in the Appendix B. 
Table 31: Mercury Inventory

\begin{tabular}{|c|c|c|c|c|c|c|c|}
\hline \multirow[b]{2}{*}{ Source } & \multirow[b]{2}{*}{$\begin{array}{l}\text { Input } \\
(\mathrm{kg} / \mathrm{y})\end{array}$} & \multicolumn{6}{|c|}{ Output $(\mathrm{kg} / \mathrm{y})$} \\
\hline & & Air & Water & Land & $\begin{array}{c}\text { By- } \\
\text { products } \\
\text { and } \\
\text { impurities }\end{array}$ & $\begin{array}{c}\text { General } \\
\text { waste }\end{array}$ & $\begin{array}{c}\text { Sector } \\
\text { specific waste } \\
\text { treatment } \\
\text { /disposal }\end{array}$ \\
\hline \multicolumn{8}{|l|}{ Energy Consumption and Fuel Production } \\
\hline Coal Combustion in Large Power Plants & 10551 & 9284.9 & - & - & - & - & 1266.1 \\
\hline Other Coal Uses & 3859.7 & 3859.7 & - & - & - & - & - \\
\hline Oil Extraction & 8.16 & - & 1.6 & - & - & - & - \\
\hline Oil Refining & 71.4 & 17.9 & 0.7 & - & - & - & 10.7 \\
\hline $\begin{array}{l}\text { Combustion/use of Petroleum Coke and } \\
\text { Heavy Oil }\end{array}$ & 312 & 312 & - & - & - & - & - \\
\hline $\begin{array}{l}\text { Combustion/use of Diesel, Gasoil, } \\
\text { Petroleum, Kerosene }\end{array}$ & 91 & 91 & - & - & - & - & - \\
\hline Extraction and Processing of Natural Gas & 79.3 & 11.9 & 15.9 & - & 23.8 & - & 27.8 \\
\hline Use of Pipeline Gas (consumer quality) & 10 & 10 & - & - & - & - & - \\
\hline Biomass Fired Power and Heat Production & 245 & 245 & - & - & - & - & - \\
\hline \multicolumn{8}{|c|}{ Domestic Production of Metals and Raw Materials } \\
\hline Production of Copper from Concentrates & 4710 & 471 & 94.2 & - & 1978.2 & - & 2166.6 \\
\hline $\begin{array}{l}\text { Gold Extraction by Methods Other than } \\
\text { Mercury Amalgamation }\end{array}$ & 6100 & 244 & 122 & 5490 & 244 & - & - \\
\hline Alumina production from bauxite & 200 & 30 & 20 & - & - & 130 & 20 \\
\hline Primary ferrous metal production & 1790 & 1700.5 & - & - & - & - & 89.5 \\
\hline Cement production & 7839 & 5879.3 & - & - & 1959.8 & - & - \\
\hline
\end{tabular}


Table 31 (continued)

\begin{tabular}{|c|c|c|c|c|c|c|c|}
\hline \multirow[b]{2}{*}{ Source } & \multirow[b]{2}{*}{$\begin{array}{l}\text { Input } \\
(\mathrm{kg} / \mathrm{y})\end{array}$} & \multicolumn{6}{|c|}{ Output $(\mathrm{kg} / \mathrm{y})$} \\
\hline & & Air & Water & Land & $\begin{array}{c}\text { By- } \\
\text { products } \\
\text { and } \\
\text { impurities }\end{array}$ & $\begin{array}{c}\text { General } \\
\text { waste }\end{array}$ & $\begin{array}{c}\text { Sector } \\
\text { specific } \\
\text { waste } \\
\text { treatment } \\
\text { /disposal } \\
\end{array}$ \\
\hline \multicolumn{8}{|c|}{ Intentional Use of Mercury in Industrial Processes and Consumer Products } \\
\hline Production of Hg Thermometers & 6 & 0.1 & 0.03 & 0.6 & - & 0.6 & 0.1 \\
\hline Consumption of $\mathrm{Hg}$ Thermometers & 1319 & 131.9 & 395.7 & - & - & 791.6 & - \\
\hline Production of Light Sources with Mercury & 476 & 4.8 & 2.4 & 47.6 & - & 47.6 & 4.8 \\
\hline Use of Light Sources with Mercury & 2445 & 122.3 & - & - & - & 2322.8 & - \\
\hline $\begin{array}{l}\text { Production and Use of Batteries with } \\
\text { Mercury }\end{array}$ & 675 & - & - & - & - & 675 & - \\
\hline $\begin{array}{l}\text { Production and Use of Electrical Switches } \\
\text { and Relays with Mercury }\end{array}$ & 5088 & 508.8 & - & 508.8 & - & 4070.4 & - \\
\hline Use of Dental Amalgam Fillings & 4226 & & & & & & \\
\hline \multicolumn{2}{|c|}{ Prep. of fillings at dentist clinics } & 84.5 & 591.6 & - & 2535.6 & 507.1 & 507.1 \\
\hline \multicolumn{2}{|c|}{ Use- from fillings in the mouth } & - & 50.7 & - & - & - & - \\
\hline \multicolumn{2}{|c|}{ Disposal } & - & 760.7 & - & 152.1 & 304.3 & 304.3 \\
\hline Use of medical blood pressure gauges & 400 & 40 & 120 & - & - & 240 & - \\
\hline Use of manometers and gauges & 363 & 36.3 & 108.9 & - & - & 217.9 & - \\
\hline Use of mercury in laboratories & 726 & - & 242 & - & - & 242 & 242 \\
\hline \multicolumn{8}{|l|}{ Crematoria and Cemeteries } \\
\hline Cemeteries & 937.5 & - & - & 937.5 & - & - & - \\
\hline
\end{tabular}


Table 31 (continued)

\begin{tabular}{|c|c|c|c|c|c|c|c|}
\hline \multirow[b]{2}{*}{ Source } & \multirow[b]{2}{*}{$\begin{array}{l}\text { Input } \\
(\mathrm{kg} / \mathrm{y})\end{array}$} & \multicolumn{6}{|c|}{ Output $(\mathrm{kg} / \mathrm{y})$} \\
\hline & & Air & Water & Land & $\begin{array}{c}\text { By- } \\
\text { products } \\
\text { and } \\
\text { impurities }\end{array}$ & $\begin{array}{l}\text { General } \\
\text { waste }\end{array}$ & $\begin{array}{c}\text { Sector } \\
\text { specific } \\
\text { waste } \\
\text { treatment } \\
\text { /disposal } \\
\end{array}$ \\
\hline \multicolumn{8}{|l|}{ General Waste } \\
\hline Incineration of Hazardous Waste & 1026 & 923.4 & - & - & - & - & 102.6 \\
\hline $\begin{array}{l}\text { Incineration and Open Burning of Medical } \\
\text { Waste }\end{array}$ & 497 & 447.3 & - & - & - & - & 49.7 \\
\hline Sewage Sludge Incineration & 17 & 15.3 & - & - & - & - & 1.7 \\
\hline Open Fire Waste Burning & 670 & 670 & - & - & - & - & - \\
\hline Controlled Landfills/Deposits* & 11856.5 & 118.6 & 1.2 & - & - & - & - \\
\hline Informal Dumping of General Waste & 1000 & 100 & 100 & 800 & - & - & - \\
\hline Waste Water System/Treatment* & 1726.8 & - & 863.4 & 345.4 & - & 259 & 259 \\
\hline
\end{tabular}

*Calculations are shown in Section 6.1.1 and 6.1.2 


\section{CHAPTER 6}

\section{SUBSTANCE FLOW ANALYSIS OF MERCURY}

In this chapter, SFA of Mercury in Turkey is developed. For the formation of SFA diagram, input and output estimates from different release sources which are calculated in Chapter 5 during inventory development are used. Calculated output releases from the major group of activities are linked to the other sources and environmental compartments in order to identify mercury pathways in Turkey. SFA diagram for mercury in Turkey is presented in Figure 6 as tons per year.

In the SFA diagram formed, major source categories causing mercury releases are shown at the most left of the Figure 6. Mercury input to these sources can be grouped into two; mercury naturally found and mercury imported in products. Mercury naturally found, which is presented with "Lithosphere" box in the diagram, is the source of the releases from the activities in which fossil fuel is burned or mining activities take place. On the other hand, another source of mercury is imported mercury. It is imported to the country in products or in dental amalgam fillings. This source is shown with "I" in the diagram.

After determination of mercury input values, calculated output releases from the Mercury Toolkit are distributed to the intermediate or final steps which are "Air", "Water" and "Land" as shown at the right side of the diagram formed. "General Waste Management" including landfilling and incineration activities and "Wastewater Treatment Plants" are considered as the intermediate steps of mercury pathways. Calculated output releases from the toolkit, named "General waste" and "Sector Specific Waste Treatment", are linked to the box named "General Waste Management" during the formation of SFA diagram. Calculated air releases are 
directly linked to the box "Air" as atmospheric releases, and land releases to the box named "Land".

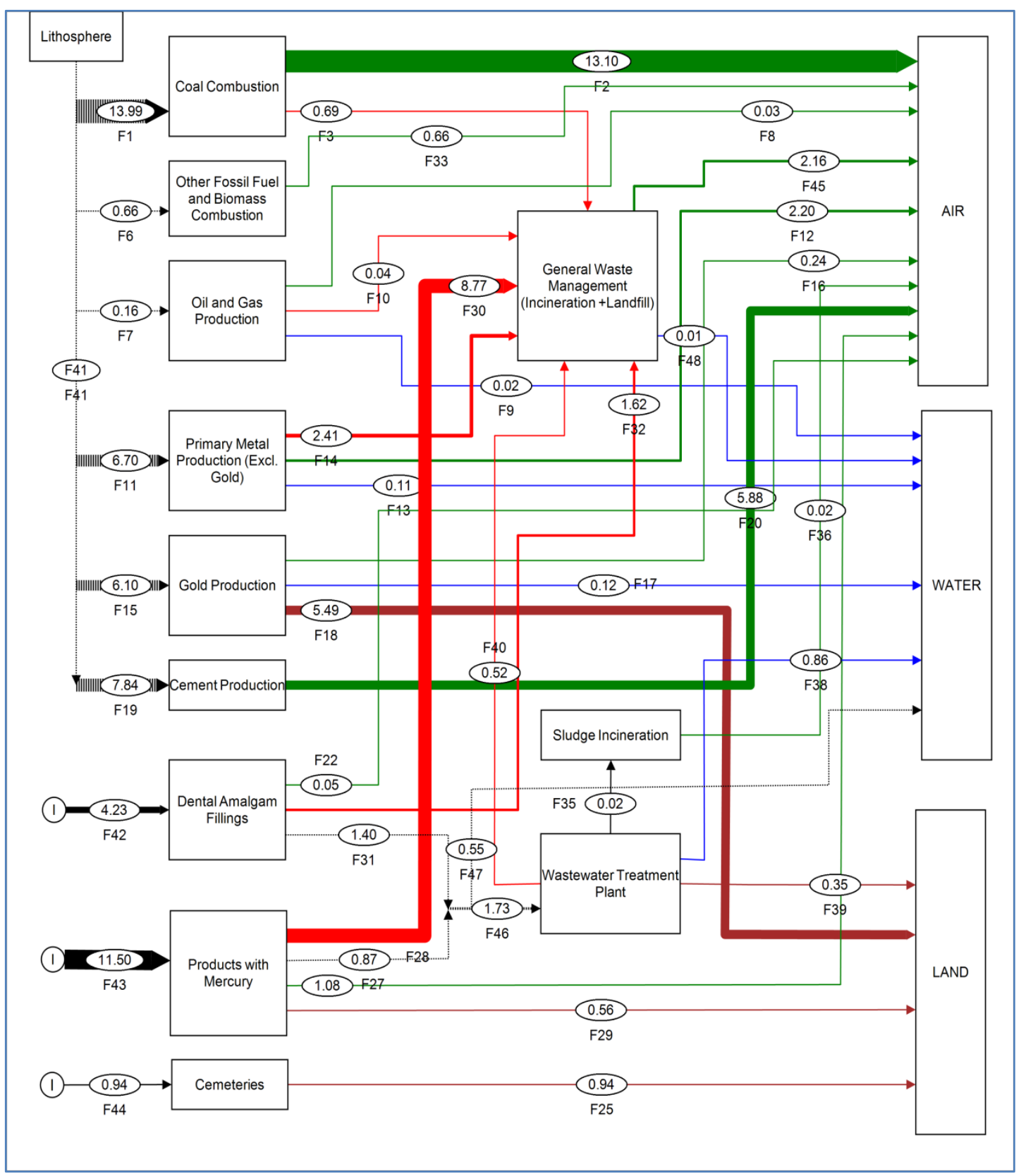

Figure 6: SFA diagram of mercury in Turkey

Wastewater produced from the use of products containing mercury is linked to the box "Wastewater Treatment Plant". However, mercury releases from other sources to water are not linked to the "wastewater treatment plants" since while calculating output releases output distribution factors assuming WWTPs were used. 
According to TSI, $24 \%$ of wastewater originated from the "use of products with mercury" and "dental amalgam fillings" are found to be directly discharged to surface waters without being treated and the remaining portion sent to the WWTPs. Therefore, this pathway of mercury is shown separately in the SFA diagram. Output releases calculated by toolkit as by-products and impurities with mercury content is not shown in the SFA diagram formed, since it circulates in the market and estimated mercury input and outputs of the source remains in the system boundary.

\subsection{Balancing}

During the formation of SFA of mercury, it is observed that estimated mercury input from mercury toolkit for the "Waste Management" and "Wastewater Treatment" categories would not be consistent with the mercury input required for the formation of SFA diagram if the default mercury input factors given in UNEP Mercury Toolkit were used. This inconsistency may originate from the use of overestimated input factors for the activities by the toolkit. Therefore, in this study, mercury input from the diagram formed is used for the estimation of mercury input factors of municipal solid waste and wastewater in Turkey. This approach is consistent with that of Brunner \& Ma (2009) who indicated that composition of wastes like municipal solid waste can be estimated with the help of SFA methodology. Mercury input factors for municipal solid waste and wastewaters are estimated from the SFA diagram formed, by dividing mercury input to amount of general waste landfilled and wastewater treated in a year in Turkey.

\subsubsection{Balancing of "Wastewater Treatment"}

In order to determine mercury input factor which is the mercury content of wastewaters produced in Turkey, mercury input from municipal wastewaters produced is found as $2272.1 \mathrm{~kg} / \mathrm{y}$ from the SFA diagram formed. Amount of wastewater produced in Turkey is gathered as 3,582,131,000 $\mathrm{m}^{3} / \mathrm{y}$ from Turkish Waste Statistics Database (TSI, 2013c). Therefore, average estimated mercury content of municipal wastewaters in Turkey is determined according to mercury 
input from the SFA diagram. It is estimated by dividing mercury input value found by the amount of wastewaters produced in Turkey as follows;

$$
\frac{2272.1 \frac{\mathrm{kg}}{\mathrm{y}}}{3582131000 \frac{\mathrm{m}^{3}}{y}}=0.63 \frac{\mathrm{mg}}{\mathrm{m}^{3}}
$$

According SFA of Mercury in Turkey, it can be concluded that mercury content of municipal wastewaters is found as $0.63 \mathrm{mg} / \mathrm{m}^{3}$. The mercury content found is also consistent with range defined by UNEP as shown in Table 32 (UNEP-CB, 2013b).

Table 32: Input factor range for mercury in wastewater (UNEP-CB, 2013b)

\begin{tabular}{|l|c|}
\hline \multicolumn{1}{|c|}{ Material } & $\begin{array}{c}\text { Input factor } \\
\left(\mathbf{m g ~ m e r c u r y} / \mathbf{m}^{\mathbf{3}}\right)\end{array}$ \\
\hline Municipal wastewater & $0.5-10$ \\
\hline
\end{tabular}

According to Turkish Waste Statistics Database, $76 \%$ of wastewater produced in Turkey is discharged after being treated while the remaining portion is given away without treatment. 2,719,151,000 $\mathrm{m}^{3} / \mathrm{y}$ wastewater is treated in WWTPs $862,980,000 \mathrm{~m}^{3} / \mathrm{y}$ is discharged without being treated (TSI, 2013c). Therefore, it is assumed that $24 \%$ of mercury input from wastewater is directly discharged to surface waters without being treated. The amount of mercury discharged to water is calculated as follows;

$2272.1 \frac{\mathrm{kg}}{\mathrm{y}} \times 0.24=545.3 \frac{\mathrm{kg}}{\mathrm{y}}$ direct releases to water from untreated $\mathrm{w} w$

By subtracting the amount of mercury discharged to water from untreated wastewater from the total amount of mercury input from wastewaters, mercury input to WWTPs is found as $1726.8 \mathrm{~kg} / \mathrm{y}$. In order to estimate mercury releases to the environmental 
compartments from WWTPs, the default distribution factors given in Table 33 are used and mercury release estimates are calculated as;

$$
\begin{gathered}
1726.8 \frac{\mathrm{kg}}{\mathrm{y}} \times 0.5=863.4 \frac{\mathrm{kg}}{\mathrm{y}} \text { water releases } \\
1726.8 \frac{\mathrm{kg}}{\mathrm{y}} \times 0.2=345.4 \frac{\mathrm{kg}}{\mathrm{y}} \text { land releases } \\
1726.8 \frac{\mathrm{kg}}{\mathrm{y}} \times 0.15=259 \frac{\mathrm{kg}}{\mathrm{y}} \text { general waste } \\
1726.8 \frac{\mathrm{kg}}{\mathrm{y}} \times 0.15=259 \frac{\mathrm{kg}}{\mathrm{y}} \text { sector specific treatment/disposal }
\end{gathered}
$$

Table 33 : Output distribution factors for wastewater treatment (UNEP-CB, 2013b)

\begin{tabular}{|c|c|c|c|c|}
\hline Source & Water & Land & $\begin{array}{c}\text { General } \\
\text { Waste }\end{array}$ & $\begin{array}{c}\text { Sector specific } \\
\text { treatment/disposal }\end{array}$ \\
\hline Wastewater treatment & 0.5 & 0.2 & 0.15 & 0.15 \\
\hline
\end{tabular}

\subsubsection{Balancing of "Waste Management"}

Average estimated mercury content of municipal solid waste of Turkey, which is also named as mercury input factor in this study, is calculated by using the input value gathered from the SFA diagram. For the balancing of SFA diagram, mercury input coming to the waste management category, which is the intermediate step of mercury pathway is found as $14049.5 \mathrm{~kg} / \mathrm{y}$. While doing this calculation, only mercury content of municipal waste is considered because there is not as much as mercury input from the incineration of solid waste as landfills. Therefore, the amount of mercury input coming from the incineration of waste in Turkey, which is $2193 \mathrm{~kg} / \mathrm{y}$, is subtracted from the whole mercury input coming to the Waste Management category in SFA diagram and found as $11856.5 \mathrm{~kg} / \mathrm{y}$. Amount of waste landfilled in 
Turkey is found as 24,329,096 tons for the year of 2010 (TSI, 2013c). Mercury content of municipal solid waste was found by dividing mercury input value found from SFA by the amount of waste landfilled in Turkey as follows;

$$
\frac{11856.5 \frac{\mathrm{kg}}{\mathrm{y}}}{24329096 \frac{\mathrm{t}}{\mathrm{y}}}=0.48 \frac{\mathrm{mg}}{\mathrm{kg}}
$$

As it is mentioned by van Velzen, Langenkamp, \& Herb (2002) mercury content in waste has showed a decrease because of measures taken for the reduction of mercury use. In Canada, 1-2 g/t mercury in waste was reported (Guest, 1992 as cited in van Velzen et al., 2002) In addition, based on the information given in the study, mercury content of MSW decreased from $4 \mathrm{~g} / \mathrm{t}$ to $2 \mathrm{~g} / \mathrm{t}$ from 1990 to 1997. Therefore, it is possible to say that the results of this study are not very different from the literature reports.

Table 34: Output distribution factors for landfilling (UNEP-CB, 2013b)

\begin{tabular}{|l|c|c|}
\hline \multicolumn{1}{|c|}{ Source } & Air & Water \\
\hline Landfilling of waste & 0.01 & 0.0001 \\
\hline
\end{tabular}

Mercury release estimates from the landfills are calculated by using the output distribution factors given in Table 34 as follows;

$$
\begin{gathered}
11856.5 \frac{\mathrm{kg}}{\mathrm{y}} \times 0.01=118.6 \frac{\mathrm{kg}}{\mathrm{y}} \text { air releases } \\
11856.5 \frac{\mathrm{kg}}{\mathrm{y}} \times 0.0001=1.2 \frac{\mathrm{kg}}{\mathrm{y}} \text { water releases }
\end{gathered}
$$

Calculated mercury releases from landfills are summed up with the releases from other sources regarding to incineration of waste (excl. informal dumping of general waste) and presented as mercury releases from the "Waste Management" category in 
the SFA diagram formed. Estimated mercury releases are $2174.6 \mathrm{~kg} / \mathrm{y}$ to air and 1.2 $\mathrm{kg} / \mathrm{y}$ to water.

\subsection{Mercury Releases to the Environment}

Sources contributing to the environmental mercury releases can be identified by trace backing the mercury flows on the SFA diagram formed. Three major environmental compartments; air, water and land are considered as the ultimate point of mercury pathways. Sources of mercury are grouped into two; mercury naturally found in the lithosphere and imported mercury. According to results of the study, activities mobilizing mercury naturally found in lithosphere contribute to environmental mercury releases more. Results showed that, in Turkey, 34.38 tons of mercury is released to air, water and land in total annually. Air releases is found to be $25.37 \mathrm{t}$ $\mathrm{Hg} / \mathrm{y}$. On the other, mercury releases are estimated as $7.34 \mathrm{t} / \mathrm{y}$ to land and $1.67 \mathrm{t} / \mathrm{y}$ to water. Therefore, it is possible to say that most of the mercury input to the environment is found to be in the form of atmospheric releases. Distribution of mercury input to different environmental compartments is presented in Figure 7 as percentages.

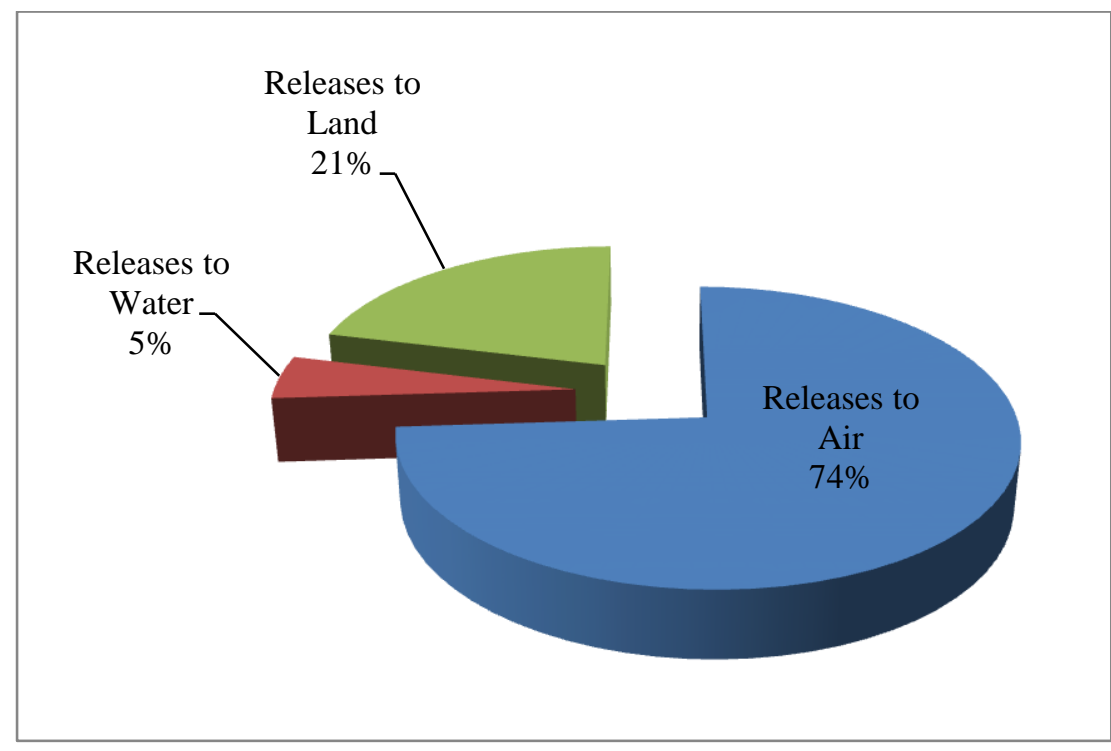

Figure 7: Distribution of mercury to different environmental media in Turkey 


\subsubsection{Mercury Releases to Air}

Estimated mercury releases to air from the SFA diagram formed are presented in Figure 8 based on their sources. According to the findings of the study, the most predominant source contributing to the atmospheric mercury releases is found to be coal combustion for electricity production, heating and industrial use. The results show that 13.1 tons of $\mathrm{Hg}$ is released to atmosphere in a year from coal combustion with the aim of electricity and heat production in Turkey. It forms the highest portion $(52 \%)$ of total atmospheric mercury releases which is estimated as $25.37 \mathrm{t} / \mathrm{y}$. With regard to the findings of the study conducted in Mediterranean Region with the aim of determining atmospheric mercury releases from different countries, amount of mercury releases to the atmosphere from coal combustion was found as $7.2 \mathrm{t} / \mathrm{y}$, being the major source of atmospheric mercury releases (44.6\%) in Turkey in 1995. The study also projected total mercury release to the atmosphere in Turkey for the year of 2010 as 21.6 t/y (Pirrone, Costa, Pacyna, \& Ferrara, 2001).

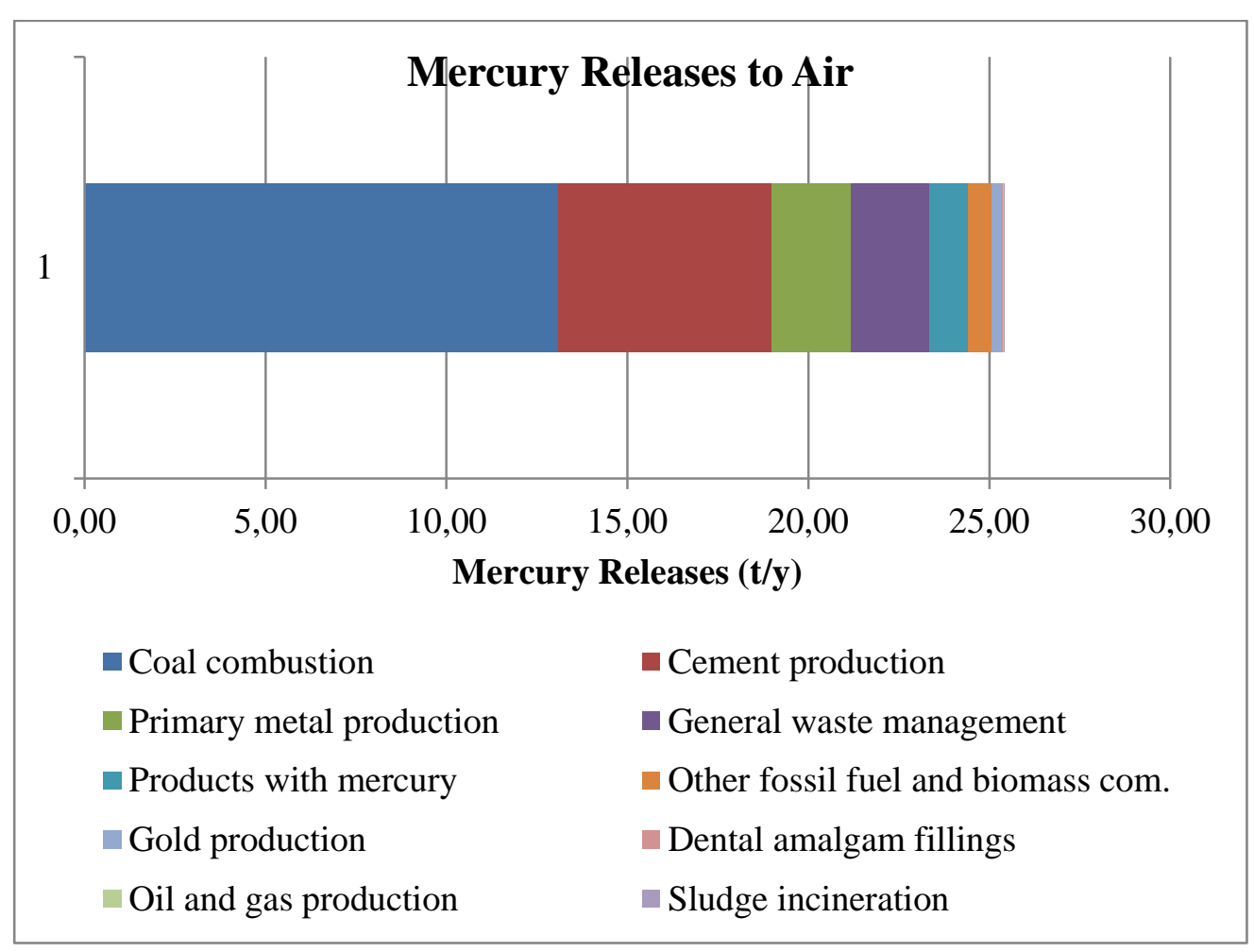

Figure 8: Contribution of sources to mercury releases to air in Turkey 
As it is given in Chapter 5, coal combustion is divided into two groups while estimating mercury releases; coal combustion in large power plants ( $>300 \mathrm{MW})$ and other coal use covering coal combustion in smaller power plants $(<300 \mathrm{MW})$, industrial and residential coal use. Atmospheric mercury releases is estimated as 9.3 t/y from coal combustion in large power plants and $3.9 \mathrm{t} / \mathrm{y}$ from other coal uses.

Turkey's demand for coal combustion with the aim of energy production in large power plants has been increasing since 1990 and it is an important energy source for Turkey's future energy policies. According to World Energy Council (WEC), Turkey supplies $29 \%$ of its energy demand, which is 33.5 million MEP, from coal combustion as presented in Figure 9. Therefore, since coal combustion in large power plants is the highest contributor of atmospheric mercury releases and it has a considerable share in supplying Turkey's energy demand, it should be handled as a primary concern.

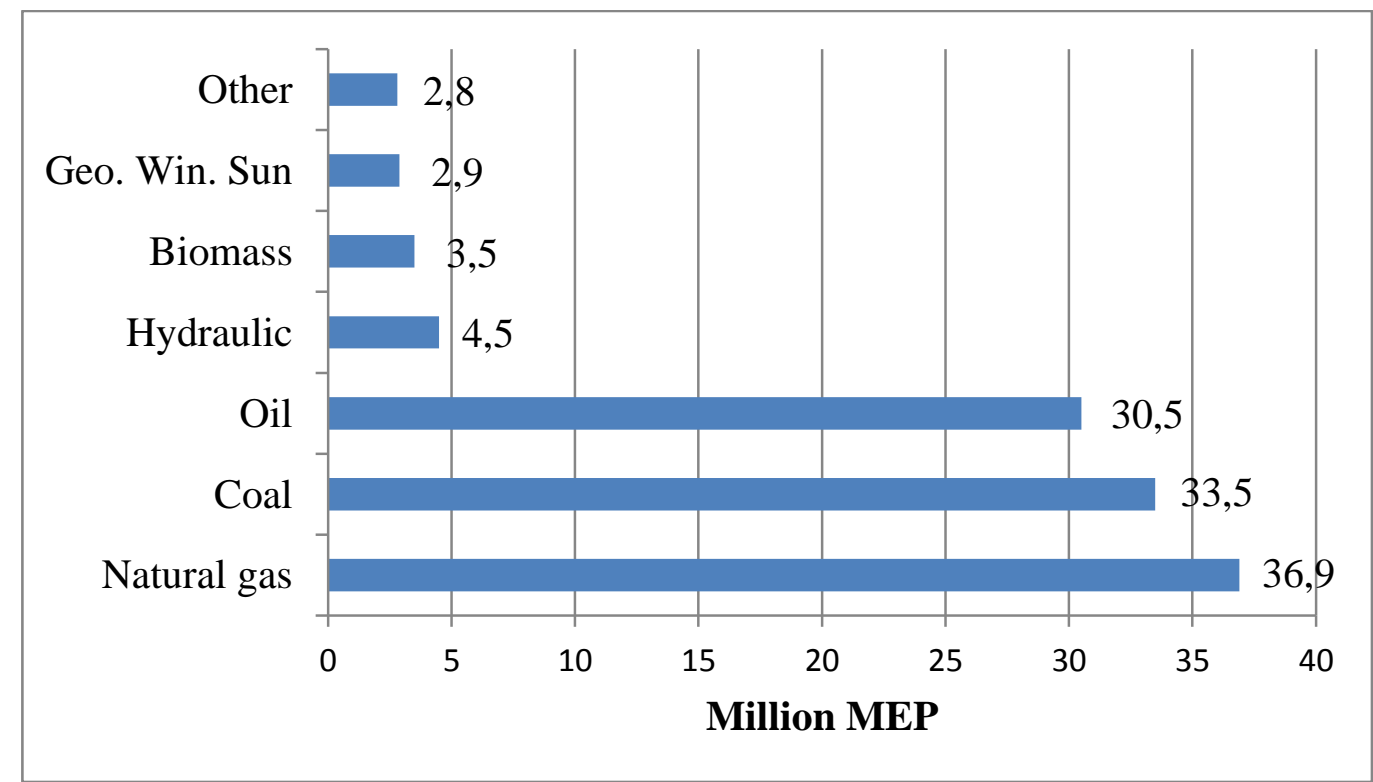

Figure 9: Contribution of energy sources to primary energy supply in Turkey in 2011 (WEC, 2013)

As it can be seen in Figure 8, second major source of atmospheric mercury releases in Turkey is found as cement production with $5.88 \mathrm{t} / \mathrm{y}$ constituting $23 \%$ of total 
releases to the atmosphere. Turkey is known to be the largest cement producer in Europe and the sixth in the world. Therefore, reduction of mercury releases from cement production in Turkey could be very helpful for the reduction of atmospheric release (MoSIT, 2013a). Masekoameng, Leaner, \& Dabrowski, (2010) also found cement production, which is 3.9 tons of mercury in South Africa for the year of 2006, as the second major contributor of atmospheric mercury releases.

Fewer quantities (about $8 \%$ for each) of air releases can be traced back to primary metal production (excluding gold) and general waste management from the SFA diagram. Contribution of sources to mercury releases from primary metal production category from largest to smallest are found as, primary ferrous metal production, production of copper from concentrates and alumina production from bauxite, respectively. Under the waste management category, incineration of hazardous and medical waste and open fire waste burning are the predominant sources. Contribution of other sources to atmospheric releases are found be in smaller amounts.

\subsubsection{Mercury Releases to Water}

Sources contributing to mercury releases to water, which are found from the SFA diagram, are presented in Figure 10. According to the findings of the study, 1.67 tons of mercury in total is released to water in a year in Turkey. WWTPs consist $53 \%$ of the releases with $0.86 \mathrm{t} / \mathrm{y}$ mercury release. Even if WWTPs are the intermediate steps of mercury releases, they are responsible for most of the mercury in water. In addition, wastewaters discharged to water without being treated also contributes a significant share, which is about $33 \%$. In Turkey, 0.55 tons of mercury is found to be released to the surface waters through untreated wastewaters. Thus, it is possible to say that wastewaters containing mercury and their management should be taken into consideration in order to control mercury in surface waters.

It can be observed from the SFA diagram (Figure 6) by trace backing the flows that mercury in wastewaters mainly originates from the production and use of products with mercury, especially from dental clinics because of the amalgam fillings used. 
Thus, it can be concluded that more strict control of mercury use in products or control of discharge of wastewaters to the wastewater treatment systems could be helpful for decreasing mercury releases to water.

Small fraction (about $7 \%$ for each) of mercury releases $(0.1 \mathrm{t} / \mathrm{y}$ for each) to water are found to be originated from the primary production of metals and gold extraction. Releases from oil and gas production and general waste management to water are found to be insignificant compared to above-mentioned major sources.

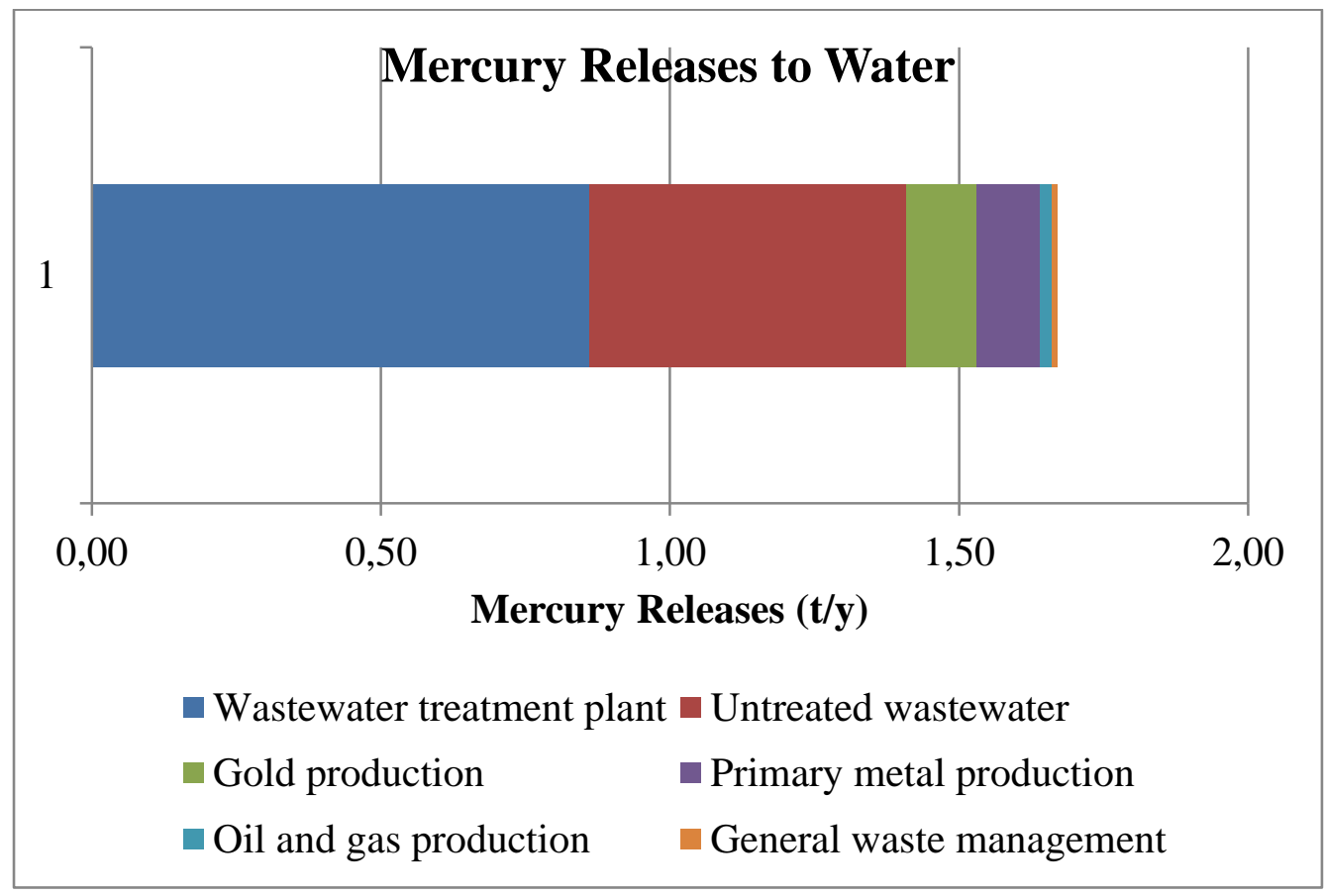

Figure 10: Contribution of sources to mercury releases to water in Turkey

\subsubsection{Mercury Releases to Land}

From the SFA diagram formed (Figure 6), mercury releases to land from different sources are found as presented in Figure 11. According to the results of the study, gold mining is found to be the major contributor of mercury releases to land with $5.49 \mathrm{t} \mathrm{Hg} / \mathrm{y}$ output. It contributes $75 \%$ of total mercury releases to land which is 7.34 $\mathrm{t} / \mathrm{y}$. It is better to note that gold extraction has showed a sharp increase in the last decade in Turkey. Therefore, assuming an increase in the near future, gold mining 
should be considered as a priority source in order to provide good management of mercury releases to land from the activity.

Fewer quantities of mercury which is $0.94 \mathrm{t} / \mathrm{y}$ is released from cemeteries to land because of the amalgam fillings in the corpses buried. Products containing mercury are also found to be responsible for mercury releases to land due to the informal dumping of products. Because of the land application and wild dumping of sludge from WWTPs, they are found to be sources of mercury releases with $0.35 \mathrm{t} \mathrm{Hg} / \mathrm{y}$ release.

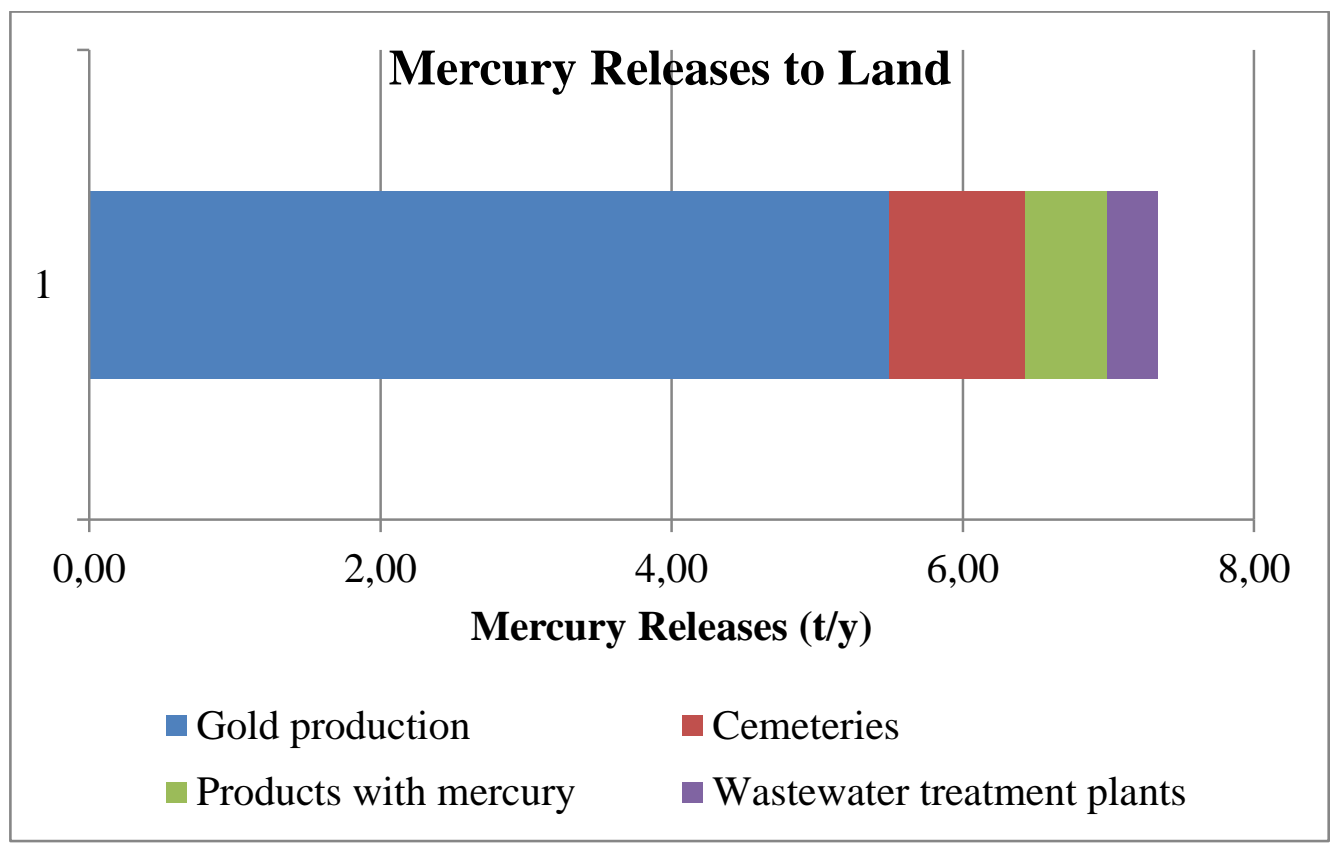

Figure 11: Contribution of sources to mercury releases to land in Turkey

\subsubsection{What to do to decrease environmental mercury releases?}

Reduction of environmental mercury releases from identified sources could be helpful in order to control of mercury in the environment, therefore for the implementation of related regulation. However, this should be done in a feasible way so that both environment and facilities do not suffer. 
In the literature there are different studies available regarding to control of mercury releases from different contributing sources. For example, UNEP has published reports within the concept of Global Mercury Partnership.

Since coal combustion with the aim of electricity production has been found as a major source of atmospheric mercury releases in most of the countries, different documents are published online on the web page of UNEP which is http://www.unep.org/chemicalsandwaste/Mercury/GlobalMercuryPartnership/Coalco mbustion/Reports/tabid/4492/language/en-US/Default.aspx.

In the report named "Processes optimization Guidance for Reducing Mercury Emissions from Coal Combustion in Power Plants", some information about reduction of environmental mercury releases like improvement plant efficiency, coal treatment, co-benefit removal and mercury specific technologies are explained in detail. The report is publicly available on UNEP's web page given above.

For the control of mercury releases from cement industry, European Cement Research Academy's Technical Report named “Guidance Document on BAT-BEP for Mercury in the Cement Industry" which is available on the web page of: http://www.unep.org/chemicalsandwaste/Portals/9/CSI_Hg-

Report_final_10_06_13.pdf could be useful. In the report, mercury removal methods and mercury monitoring techniques are explained.

As it is mentioned before, gold mining could be an important source for environmental mercury releases due to natural mercury content of gold ore even if mercury amalgamation technique is not used. In large scale sites, the use of pollution control techniques can help to reduce atmospheric mercury releases. In addition, mercury releases to land totally depend on how the residues are managed in the facilities (UNEP-CB, 2013b).

Use of mercury in household products and dental clinics are responsible for the mercury in WWTPs. Therefore, in order to control mercury in WWTPs, mercury use in products and dental clinics should be considered. Increasing limitations on the 
import, export and use of mercury in products will affect the mercury coming to WWTPs. On the other hand, use of basic filtration systems in dental clinics could be helpful for preventing mercury used in dental amalgam fillings to just given away city's waterway system, thus WWTPs. 


\section{CHAPTER 7}

\section{CONCLUSION}

In the present study, SFA of mercury in Turkey is carried out. This study is one-year static SFA; however, data used in the study mostly represent the years of 2010, 2011 and 2012. Possible sources contributing to environmental mercury releases are identified and mercury releases to the different environmental compartments are quantified with the help of SFA methodology. Results indicate that there is no domestic production of mercury, mercury naturally found in the lithosphere and mercury imported are the sources of mercury releases in Turkey. It is found that major mercury input to the environment is by anthropogenic activities mobilizing mercury naturally found in the lithosphere. These activities are found to be responsible for the most of the mercury releases to the environment, especially to air and land; however, intentional use of mercury in products and processes still continues to be important, especially for water releases through the waste water systems.

Results of the study show that in Turkey, 34.38 tons of mercury is released to air, water and land annually. According to the results, $74 \%$ of the mercury output, which is $25.37 \mathrm{t} / \mathrm{y}$, is found to be in the form of atmospheric releases. Coal combustion with the aim of electricity and heat production is found to be the major contributor of mercury releases to air. Therefore, policy decision makers should take coal combustion into consideration, especially in large power plants. Cement production is found to be the second major source of mercury in air because of fossil fuel combustion during production.

Mercury release to the land is estimated as $7.34 \mathrm{t} / \mathrm{y}$ corresponding $21 \%$ of total mercury releases to the environment. Gold mining is found to be major source for 
mercury releases to the land. Since gold ore contains mercury impurities, high amounts of mercury can be released to land from solid or liquid residues which are disposed of. It is possible to say that, policy makers should focus on good management of solid residues placed in surface impoundments in order to prevent mercury pollution.

Even if, very small amount of mercury releases $(1.67 \mathrm{t} / \mathrm{y}$ consisting $5 \%$ of total mercury output) to water is estimated compared to other compartments, WWTPs are found as the largest source of mercury in water with the highest contribution. Then, untreated wastewaters directly discharged to the surface waters in Turkey comes as the second. However, mercury in wastewater originates from the intentional use of mercury in products. Among them, the use of mercury in dental clinics has the major contribution. Therefore, in order to control mercury in wastewater and WWTPs, the ministry should control the discharge of mercury to city's' waterway systems from dental clinics.

Even the fate of mercury in the environment is not studied within the scope of this study, it is obvious to say that mercury in the air may settle into water and land through atmospheric deposition and affect the quality. Mercury falls into the ground with rain or snow (wet deposition) or due to the gravity or wind (dry deposition). When it reaches to the ground, it contributes to the mercury concentrations there. Since there is high amounts of atmospheric mercury releases (74\% of all mercury releases to the environment), it should be considered as an important source of mercury in different environmental media especially in water and further investigated in Turkey. 


\section{CHAPTER 8}

\section{RECOMMENDATIONS}

In this study, for the development of mercury inventory of Turkey, Mercury Toolkit Level 1 which is developed by UNEP Chemical's Branch is preferred to be used due to the lack of input and output factors specific to Turkey. Toolkit includes default input and outputs factors which are required for the estimation of mercury input to environment from an activity/source and output distribution factors for the distribution of mercury input to different environmental compartments. When available, a range of input factor is defined by UNEP and usually the medium value of the range is used for the estimation of mercury releases from a source/activity. However, the use of input and output distribution factors, which are specific to sources/activities in Turkey, would provide more accurate results. It is also noted by UNEP that these factors are preliminary and require further revisions.

While collecting activity rate data, which is the volume of activity per unit of time, different databases and industrial reports, are used. In order to get more accurate results, it would be better to use the activity rate data which is obtained directly from the facility.

Nevertheless, this study is the first to exhibit the existing situation in Turkey about mercury. In addition to quantitative results, the study gives some qualitative information about mercury release sources and pathways in Turkey. With these properties, this study can be useful for policy decision makers, since results can be further developed with the aim of meeting with the regulatory framework, especially environmental quality standards by focusing on the major mercury release sources/activities. 


\section{REFERENCES}

ACAP. (2005). Arctic Mercury Releases Inventory. Arctic Council Action Plan to Eliminate Pollution of the Arctic (ACAP) \& Danish Environmental Protection Agency. Danish EPA, Copenhagen.

Allchin, D. (n.d.). The Poisoning of Minimata. Retrieved October 24, 2014, from https://www1.umn.edu/ships/ethics/minamata.htm

Andersson, H., Cousins, A. P., Westerdahl, J., Braun, H., Bergfors, L., Brorströmlundén, E., ... Nielsen, U. (2012). COHIBA Project WP4 FINAL REPORT Major Sources and Flows of the Baltic Sea Action Plan Hazardous Substances. Control of Hazardous Substances in the Baltic Sea Region (COHIBA).Stockholm.

Asari, M., Fukui, K., \& Sakai, S.-I. (2008). Life-cycle flow of mercury and recycling scenario of fluorescent lamps in Japan. The Science of the Total Environment, 393(1), 1-10. doi:10.1016/j.scitotenv.2007.08.062

ATSDR. (1999). Public Health Statement Mercury. Agency for Toxic Substances and Disease Registry (ATSDR). Atlanta,GA. Retrieved December 15, 2014, from http://www.atsdr.cdc.gov/phs/phs.asp?id=112\&tid=24

ATSDR. (2011). Mercury. Agency for Toxic Substances and Disease Registry (ATSDR). Atlanta, GA. Retrieved October 22, 2014, from http://www.atsdr.cdc.gov/substances/toxsubstance.asp?toxid=24

ATSDR. (2014). Medical Management Guidelines for Mercury. Agency for Toxic Substances and Disease Registry (ATSDR). Atlanta, GA. Retrieved December 15, 2014, from http://www.atsdr.cdc.gov/mmg/mmg.asp?id=106\&tid=24

Brunner, P. H. (2012). Substance Flow Analysis, A Key Tool for Effective Resource Management. Journal of Industrial Ecology, 16(3), 293-295. doi:10.1111/j.1530-9290.2012.00496.x

Brunner, P. H., \& Ma, H.-W. (2009). Substance Flow Analysis, An Indispensable Tool for Goal-Oriented Waste Management. Journal of Industrial Ecology, 13(1), 11-14. doi:10.1111/j.1530-9290.2008.00083.x 
Brunner, P. H., \& Rechberger, H. (2004). Practical Handbook of Material Flow Analysis. Lewis Publishers. doi:10.1016/B978-1-85617-809-9.10003-9

Cain, A., Disch, S., Twaroski, C., Reindl, J., \& Case, C. R. (2007). Substance Flow Analysis of Mercury Intentionally Used in Products in the United States. Journal of Industrial Ecology, 11(3), 61-75. doi:10.1162/jiec.2007.1214

Canadian Environmental and Metallurgical Inc. (2006). Klşladă Gold Mine Capacity Increase Report.

EC. (2005). Comission Staff Working Paper. Annex to the Communication from the Comission to the Council and the European Parliament on Community Strategy Concerning Mercury Extended Impact Assessment. European Commission (EC). Brussels.

EC. (2010). Products that Contain Mercury: Switches and Relays. Environment Canada (EC). Retrieved December 16, 2014, from http://www.ec.gc.ca/mercure-mercury/default.asp?lang=En\&n=AD4A4C541\#Relays

EC. (2012). Products that Contains Mercury: Fluorescent Lamps. Environment Canada (EC). Retrieved December 16, 2014, from http://www.ec.gc.ca/mercure-mercury/default.asp?lang=En\&n=2486b388-1

EC. (2013). Products that Contain Mercury: Thermometers and Thermostats. Environment Canada (EC). Retrieved December 16, 2014, from http://www.ec.gc.ca/mercure-mercury/default.asp?lang=En\&n=AFE7D1 A3-1

EMEP/EEA. (2013). EMEP/EEA air pollutant emission inventory guidebook 2013. Technical report No 12. Iron and Steel Production.

Finkelman, B. (2004). Personal Communication. USA: United States Geological Survey (USGS).

Fridmanis, J., Torpovs, V., \& Linde, A. (2011). COHIBA Project SUMMARY REPORT LATVIA- WP4 Identification of sources and estimation of inputs/impacts on the Baltic Sea. Control of Hazardous Substances in the Baltic Sea Region (COHIBA).Latvia.

Fukuda, N., Takaoka, M., Doumoto, S., Oshita, K., Morisawa, S., \& Mizuno, T. (2011). Mercury emission and behavior in primary ferrous metal production. 
Atmospheric Environment, 45(22), 3685-3691. doi:10.1016/j.atmosenv.2011.04.038

Gad, S. C., \& Pham, T. (2014). Mercury. In Encylopedia of Toxicology (Third Edition). doi:10.1016/B978-0-12-386454-3.00875-7

Gsodam, P., Lassnig, M., Kreuzeder, A., \& Mrotzek, M. (2014). The Austrian silver cycle: A material flow analysis. Resources, Conservation \& Recycling, 88, 7684. doi:10.1016/j.resconrec.2014.05.001

Guest, T. L. (1992). Mercury retention in fly ash using activated carbon absorption. In 5th Annual Meeting \& Exhibition of the Air \& Waste Management Association. Kansas City.

Hagreen, L., \& Lourie, B. (2004). Canadian mercury inventories: the missing pieces. Environmental Research, 95(3), 272-81. doi:10.1016/j.envres.2004.01.003

Hansen, E., \& Lassen, C. (2003). Experience with the Use of Substance Flow Analysis in Denmark. Journal of Industrial Ecology, 6(3-4).

Huang, C.-L., Ma, H.-W., \& Yu, C.-P. (2014). Substance flow analysis and assessment of environmental exposure potential for triclosan in mainland China. The Science of the Total Environment, 499(3-4), 265-75. doi:10.1016/j.scitotenv.2014.08.032

Huang, C.-L., Vause, J., Ma, H.-W., Li, Y., \& Yu, C.-P. (2014). Substance flow analysis for nickel in mainland China in 2009. Journal of Cleaner Production, 84, 450-458. doi:10.1016/j.jclepro.2013.12.079

Huang, C.-L., Vause, J., Ma, H.-W., \& Yu, C.-P. (2012). Using material/substance flow analysis to support sustainable development assessment: A literature review and outlook. Resources, Conservation and Recycling, 68, 104-116. doi:10.1016/j.resconrec.2012.08.012

Jamtrot, A., Seriki, K., \& Pettersson, M. (2010). Substance Flow Analysis for selected Priority Pollutants in Case Cities. Source Control Options for Reducing Emissions of Priority Pollutants (ScorePP) Project.

Jasinski, S. M. (1995). The materials flow of mercury in the United States. Resources, Conservation and Recycling, 15(3-4), 145-179. doi:10.1016/09213449(95)00032-1 
Lindqvist, A., \& von Malmborg, F. (2004). What can we learn from local substance flow analyses? The review of cadmium flows in Swedish municipalities. Journal of Cleaner Production, 12(8-10), 909-918. doi:10.1016/j.jclepro.2004.02.012

Littlepage, T. (2013). Mercury in Crude Oils. 2013 Marine Chemist Association Spring Seminar Series.

Masekoameng, K. E., Leaner, J., \& Dabrowski, J. (2010). Trends in anthropogenic mercury emissions estimated for South Africa during 2000-2006. Atmospheric Environment, 44(25), 3007-3014. doi:10.1016/j.atmosenv.2010.05.006

Mercury (Hg). (2014). Encylopedia Britannica. Retrieved October 20, 2014, from http://0www.britannica.com.library.metu.edu.tr/EBchecked/topic/375837/mercury

MoENR. (2013). Raw Material Production Data. Turkish Ministry of Energy and Natural Resources, Ankara.

MoEU. (2008). Regulation on Restriction of Production, Market Supply and Use of Certain Hazardous Substances and Goods Vol 27092. Turkish Ministry of Environment and Urbanization (MoEU), Official Gazette.

MoEU. (2010). Turkey's Position on Mercury. Turkish Ministry of Environment and Urbanization (MoEU). Ankara.

MoEU. (2012a). 2009-2011 D10 Sewage Sludge Production Data. Turkish Ministry of Environment and Urbanization (MoEU), TABS.

MoEU. (2012b). Regulation on Control of Waste Electronic Equipment Vol 28300. Turkish Ministry of Environment and Urbanization (MoEU), Official Gazette.

MoFAL. (2013). Regulation on Chancing Regulation on Maximum Residue Limits of Pesticides Vol 28517. Turkish Ministry of Food, Agriculture and Livestock (MoFAL), Official Gazette.

MoH. (2005). Regulation on Cosmetics Vol 25823. Turkish Ministry of Health (MoH), Official Gazette.

MoH. (2007). Regulation on Medical Devices Vol 26398. Turkish Ministry of Health $(\mathrm{MoH})$, Official Gazette. 
MoSIT. (2013a). Cement Industry Report. Turkish Ministry of Science, Industry and Technology (MoSIT), Ankara.

MoSIT. (2013b). Iron and Steel Industry Report. Turkish Ministry of Science, Industry and Technology (MoSIT), Ankara.

Pacyna, J. M. (2009). SOCOPSE Project WP2 Material Flow Analysis for selected Priority Substances.

Pirrone, N., Costa, P., Pacyna, J. M., \& Ferrara, R. (2001). Mercury emissions to the atmosphere from natural and anthropogenic sources in the Mediterranean region. Atmospheric Environment, 35, 2997-3006.

Pollution Probe. (2003). Mercury in the Environment: A Primer. Canada.ISBN 0919764-51-7.

Reisinger, H., Schöller, G., Jakl, T., Quint, R., Müller, B., Riss, A., \& Brunner, P. H. (2009). Lead , Cadmium and Mercury Flow Analysis - Decision Support for Austrian Environmental Policy. Österreichische Wasser- Und Abfallwirtschaft, 61(5-6), 63-69.

Revitt, D. M., Lundy, L., Eriksson, E., \& Viavattene, C. (2013). Comparison of pollutant emission control strategies for cadmium and mercury in urban water systems using substance flow analysis. Journal of Environmental Management, 116, 172-80. doi:10.1016/j.jenvman.2012.12.007

Sang, S., \& Lourie, B. (1997). Mercury emission inventory in ontario. Environmental Monitoring and Assesment, 47, 79-88.

SPO. (2006). Ninth Development Plan- Mining Comission Report- Lead, Zinc, Cadmium Working Group Report. Turkish State Planning Organization (SPO), Ankara.

SPO. (2008). Ninth Devolepment Plan-Chemical Industry Comission ReportPetrochemistry, Chloralkali, Synthetic Fibre and Yarn Working Group. Turkish State Planning Organization (SPO), Ankara.

Sundseth, K., Pacyna, J. M., Pacyna, E. G., \& Panasiuk, D. (2012). Substance Flow Analysis of Mercury Affecting Water Quality in the European Union. Water, Air, \& Soil Pollution, 223(1), 429-442. doi:10.1007/s11270-011-0871-0

TCE. (2013). Coal Sectoral Report 2012. Turkish Coal Enterprises (TCE), Ankara. 
TPC. (2013). Crude Oil and Natural Gas Sectoral Report 2012. Turkish Petroleum Corporation (TPO), Ankara.

TSI. (2013a). Basic Statistics Database.Turkish Statistics Institute (TSI). Retrieved January 15, 2015, from http://www.tuik.gov.tr/UstMenu.do?metod=temelist

TSI. (2013b). Foreign Trade Statistics Database. Turkish Statistics Institute (TSI). Retrieved January 15, 2015, from http://tuikapp.tuik.gov.tr/disticaretapp/menu.zul

TSI. (2013c). Municipal Waste Statistics Database. Turkish Statistics Institute (TSI). Retrieved December 10, 2013, from http://tuikapp.tuik.gov.tr/cevredagitimapp/katiatik.zul

Turkish Portable Battery Manufacturers and Importers Association. (2012). Collection and Disposal of Waste Batteries.

UNEP-CB. (2012). Mercury Toolkit Level 1., 1.2 edn. United Nations Environment Program Chemicals Branch (UNEP-CB), Geneva, Switzerland.

UNEP-CB. (2013a). Toolkit for Identification and Quantification of Mercury Releases, Guideline for Inventory Level 1 Ver.1.2. United Nations Environment Program Chemicals Branch (UNEP-CB), Geneva, Switzerland.

UNEP-CB. (2013b). Toolkit for Identification and Quantification of Mercury Releases, Reference Report and Guideline for Inventory Level 2 Ver.1.2. United Nations Environment Program Chemicals Branch (UNEP-CB), Geneva, Switzerland.

UoCCET. (2013). Industry Database. Union of Chambers and Commodity Exchanges of Turkey (UoCCET). Retrieved December 22, 2014, from http://sanayi.tobb.org.tr/kod_bulma.php

USEPA. (2014a). Mercury. United States Environment Protection Agency (USEPA). Retrieved November 08, 2014, from http://www.epa.gov/mercury/about.htm

USEPA. (2014b). Mercury: Health Effects. United States Environment Protection Agency (USEPA). Retrieved October 27, 2014, from http://www.epa.gov/mercury/effects.htm 
Van Velzen, D., Langenkamp, H., \& Herb, G. (2002). Review: Mercury in waste incineration. Waste Management \& Research, 20(6), 556-568. doi:10.1177/0734242X0202000610

Voet, E. Van Der. (1996). Substances from cradle to grave; Development of a methodology for the analysis of substance flows through the economy and environment of a region with case studies on cadmium and nitrogen compounds. Leiden University.

Voet, E. Van Der, Kleijn, R., Oers, L. Van, Heijungs, R., Huele, R., \& Mulder, P. (1995). Substance Flows Through the Economy and Environment of a Region. Environmental Science and Pollution Research, 2(2), 90-96.

WEC. (2013). Energy Report 2012. World Energy Committee-National Turkish Committee, Ankara.

WHO. (2013). Mercury and Health. World Health Organiation (WHO). Retrieved October 27, 2014, from http://www.who.int/mediacentre/factsheets/fs361/en/

Xueyi, G., Juya, Z., Yu, S., \& Qinghua, T. (2010). Substance flow analysis of zinc in China. Resources, Conservation and Recycling, 54(3), 171-177. doi:10.1016/j.resconrec.2009.07.013 


\section{APPENDIX A \\ UNEP MERCURY TOOLKIT}

UNEP has developed global mercury partnership with the aim of protecting human health from mercury releases by minimizing them. In October 2013 Minimata Convention on mercury was opened and opened for signature. And, within the concept of this goal UNEP Chemicals Branch has developed Mercury Toolkit in order to help countries to identify mercury releases in their countries by developing mercury inventory.

UNEP Mercury Toolkit has been updated in 2013 based on the feedback from who has used the toolkit. Now, toolkit is available in two different versions: Level 1 and Level 2. Both levels are publicly available on the web page: http://www.unep.org/chemicalsandwaste/Mercury/MercuryPublications/GuidanceTra iningMaterialToolkits/MercuryToolkit/tabid/4566/language/en-US/Default.aspx.

In addition to that, guidelines for Mercury Toolkit Level 1 and Level 2 and Reference Report are available on the same web page. In the guidelines, working principle of the toolkit is clearly given with the default input and output distribution factors and explanation of calculation assumptions. In addition to that, brief information about the contributing activities, some example calculations and limitations of the toolkit are explained in the guidelines.

Mercury Toolkit Level 1 includes default input and output distribution factors for the estimation of mercury releases from different sources to environmental compartments. On the other hand, in level 2, country specific input and output distribution factors can be entered for the calculation of mercury releases. Therefore, level 2 can be preferred by the countries if the required data are available. In this 
study, level 1 is used for the estimation of mercury releases. A screenshot of the toolkit from this study is presented in Figure 12 with estimated output releases.

UNEP Mercury Toolkit has been used by different countries from all over the world like Panama, Peru, Mexico, Syria, Russia, Australia, New Zealand etc. Results of the developed national inventories are available on the web page of: http://www.unep.org/chemicalsandwaste/Mercury/Informationmaterials/ReleaseInve ntories/tabid/79332/Default.aspx. 


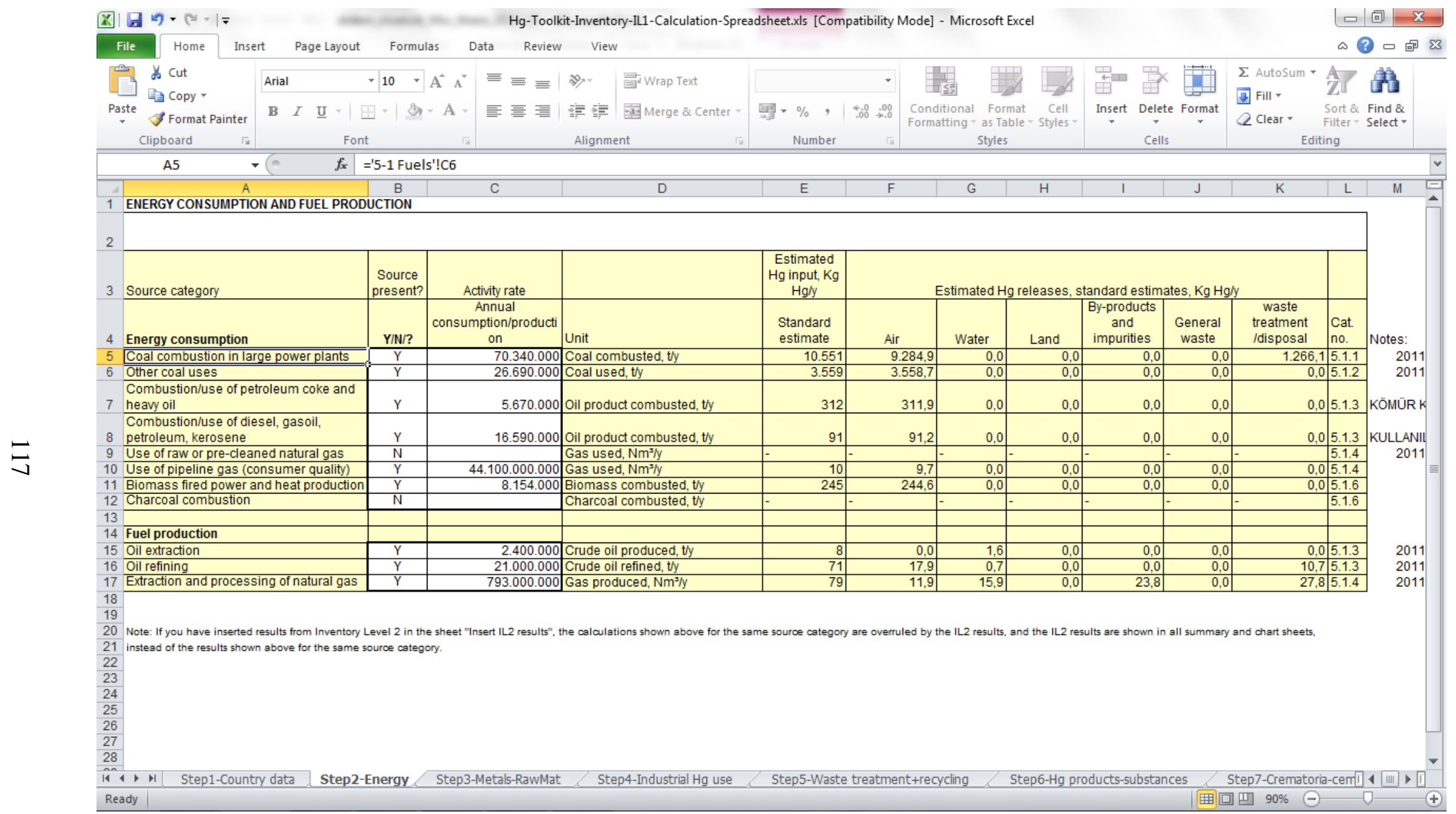

Figure 12: Screenshot of UNEP Mercury Toolkit Level 1 Step 2 Energy Consumption and Fuel Production 


\section{APPENDIX B}

\section{INPUT FACTORS AND ACTIVITY RATE DATA}

Table 35: Input Factors and Activity Rate Data Collected for Turkey

\begin{tabular}{|c|c|c|c|c|}
\hline Source & $\begin{array}{l}\text { Input } \\
\text { Factor }\end{array}$ & Reference & Activity Rate & Reference \\
\hline \multicolumn{5}{|c|}{ Energy Consumption and Fuel Production } \\
\hline $\begin{array}{l}\text { Coal combustion in } \\
\text { large power plants }\end{array}$ & $0.15 \mathrm{~g} / \mathrm{t}$ & (UNEP-CB, 2012) & $70340000 \mathrm{t} / \mathrm{y}$ & (TCE, 2013) \\
\hline Other coal uses & $0.13 \mathrm{~g} / \mathrm{t}$ & (UNEP-CB, 2012) & $29690000 \mathrm{t} / \mathrm{y}$ & (TCE, 2013) \\
\hline Oil extraction & $3.4 \mathrm{mg} / \mathrm{t}$ & (UNEP-CB, 2012) & $2400000 \mathrm{t} / \mathrm{y}$ & (WEC, 2013) \\
\hline Oil refining & $3.4 \mathrm{mg} / \mathrm{t}$ & (UNEP-CB, 2012) & $21000000 \mathrm{t} / \mathrm{y}$ & (WEC, 2013) \\
\hline $\begin{array}{l}\text { Combustion/use of } \\
\text { petroleum coke and } \\
\text { heavy oil }\end{array}$ & $55 \mathrm{mg} / \mathrm{t}$ & (UNEP-CB, 2012) & $5670000 \mathrm{t} / \mathrm{y}$ & (TPC, 2013) \\
\hline $\begin{array}{l}\text { Combustion/use of } \\
\text { diesel, gasoil, } \\
\text { petroleum, } \\
\text { kerosene }\end{array}$ & $5.5 \mathrm{mg} / \mathrm{t}$ & (UNEP-CB, 2012) & 16590000 t/y & (TPC, 2013) \\
\hline $\begin{array}{l}\text { Extraction and } \\
\text { processing of } \\
\text { natural gas }\end{array}$ & $\begin{array}{c}100 \\
\mu \mathrm{g} / \mathrm{Nm}^{3}\end{array}$ & (UNEP-CB, 2012) & $\begin{array}{c}793000000 \\
\mathrm{Nm}^{3} / \mathrm{y}\end{array}$ & (WEC, 2013) \\
\hline $\begin{array}{l}\text { Use of pipeline gas } \\
\text { (consumer quality) }\end{array}$ & $0.2 \mu \mathrm{g} / \mathrm{Nm}^{3}$ & (UNEP-CB, 2012) & $\begin{array}{c}44100000000 \\
\mathrm{Nm}^{3} / \mathrm{y}\end{array}$ & (WEC, 2013) \\
\hline $\begin{array}{l}\text { Biomass fired } \\
\text { power and heat } \\
\text { production }\end{array}$ & $0.03 \mathrm{~g} / \mathrm{t}$ & (UNEP-CB, 2012) & $8154000 \mathrm{t} / \mathrm{y}$ & (WEC, 2013) \\
\hline \multicolumn{5}{|c|}{ Domestic Production of Metals and Raw Materials } \\
\hline $\begin{array}{l}\text { Production of } \\
\text { copper from } \\
\text { concentrates }\end{array}$ & $30 \mathrm{~g} / \mathrm{t}$ & (UNEP-CB, 2012) & $157000 \mathrm{t} / \mathrm{y}$ & $(\mathrm{SPO}, 2006)$ \\
\hline $\begin{array}{l}\text { Gold extraction by } \\
\text { methods other than } \\
\text { mercury } \\
\text { amalgamation }\end{array}$ & $1 \mathrm{~g} / \mathrm{t}$ & $\begin{array}{c}\text { (Canadian } \\
\text { Environmental } \\
\text { and Metallurgical } \\
\text { Inc., 2006) }\end{array}$ & $24.4 \mathrm{t} / \mathrm{y}$ & (MoENR, 2013) \\
\hline $\begin{array}{l}\text { Alumina } \\
\text { production from } \\
\text { bauxite }\end{array}$ & $0.5 \mathrm{~g} / \mathrm{t}$ & (UNEP-CB, 2012) & $400000 \mathrm{t} / \mathrm{y}$ & $(\mathrm{SPO}, 2006)$ \\
\hline
\end{tabular}


Table 35 (continued)

\begin{tabular}{|c|c|c|c|c|}
\hline Source & $\begin{array}{l}\text { Input } \\
\text { Factor }\end{array}$ & Reference & Activity Rate & Reference \\
\hline $\begin{array}{l}\text { Primary ferrous } \\
\text { metal production }\end{array}$ & $0.05 \mathrm{~g} / \mathrm{t}$ & (UNEP-CB, 2012) & $35800000 \mathrm{t} / \mathrm{y}$ & (MoSIT, 2013b) \\
\hline Cement production & $0.13 \mathrm{~g} / \mathrm{t}$ & (UNEP-CB, 2012) & $60300000 \mathrm{t} / \mathrm{y}$ & (MoSIT, 2013a) \\
\hline \multicolumn{5}{|c|}{ Intentional Use of Mercury in Industrial Processes and Consumer Products } \\
\hline $\begin{array}{l}\text { Production of } \mathrm{Hg} \\
\text { Thermometers }\end{array}$ & $10 \mathrm{~g} / \mathrm{item}$ & (UNEP-CB, 2012) & 600 items/y & $\begin{array}{c}\text { Personal } \\
\text { communication }\end{array}$ \\
\hline $\begin{array}{l}\text { Use of Ambient air } \\
\text { temperature } \mathrm{Hg} \\
\text { thermometer }\end{array}$ & $3.5 \mathrm{~g} / \mathrm{item}$ & \multirow{3}{*}{ (UNEP-CB, 2012) } & \multirow{3}{*}{$\begin{array}{l}119457 \\
\text { items/y }\end{array}$} & \multirow{3}{*}{ (TSI, 2013b) } \\
\hline $\begin{array}{l}\text { Use of Industrial } \\
\mathrm{Hg} \text { thermometers }\end{array}$ & $10 \mathrm{~g} /$ item & & & \\
\hline $\begin{array}{l}\text { Use of Other glass } \\
\mathrm{Hg} \text { thermometers }\end{array}$ & $20.5 \mathrm{~g} / \mathrm{item}$ & & & \\
\hline $\begin{array}{l}\text { Production of } \\
\text { Discharge Lamps } \\
\text { with Mercury }\end{array}$ & $30 \mathrm{mg} /$ item & (UNEP-CB, 2012) & $\begin{array}{l}15530000 \\
\text { items/y }\end{array}$ & (UoCCET, 2013) \\
\hline $\begin{array}{l}\text { Production of UV } \\
\text { Lamps with } \\
\text { Mercury }\end{array}$ & $25 \mathrm{mg} /$ item & (UNEP-CB, 2012) & $\begin{array}{l}390925 \\
\text { items/y }\end{array}$ & (UoCCET, 2013) \\
\hline $\begin{array}{l}\text { Use of High } \\
\text { pressure sodium } \\
\text { lamp }\end{array}$ & $30 \mathrm{mg} /$ item & \multirow{5}{*}{ (UNEP-CB, 2012) } & \multirow{3}{*}{$\begin{array}{l}27000000 \\
\text { items/y }\end{array}$} & \multirow{5}{*}{ (TSI, 2013b) } \\
\hline $\begin{array}{l}\text { Use of Metal halide } \\
\text { lamp }\end{array}$ & $25 \mathrm{mg} /$ item & & & \\
\hline $\begin{array}{l}\text { Use of UV light for } \\
\text { tanning }\end{array}$ & $25 \mathrm{mg} /$ item & & & \\
\hline $\begin{array}{l}\text { Use of Florescent } \\
\text { tubes (double end) }\end{array}$ & $25 \mathrm{mg} /$ item & & $\begin{array}{l}35000000 \\
\text { items/y }\end{array}$ & \\
\hline $\begin{array}{l}\text { Use of Compact } \\
\text { florescent lamp } \\
\text { (CFL single end) }\end{array}$ & $10 \mathrm{mg} /$ item & & $\begin{array}{l}85000000 \\
\text { items/y }\end{array}$ & \\
\hline $\begin{array}{l}\text { Use of Mercury } \\
\text { oxide batteries }\end{array}$ & $320 \mathrm{~kg} / \mathrm{t}$ & \multirow{4}{*}{ (UNEP-CB, 2012) } & $1 \mathrm{t} / \mathrm{y}$ & \multirow{4}{*}{ (TSI, 2013b) } \\
\hline $\begin{array}{l}\text { Use of Zinc-air } \\
\text { button cells } \\
\text { batteries }\end{array}$ & $12 \mathrm{~kg} / \mathrm{t}$ & & $17 \mathrm{t} / \mathrm{y}$ & \\
\hline $\begin{array}{l}\text { Use of Alkaline } \\
\text { button cells } \\
\text { batteries }\end{array}$ & $5 \mathrm{~kg} / \mathrm{t}$ & & $23 \mathrm{t} / \mathrm{y}$ & \\
\hline $\begin{array}{l}\text { Use of Silver oxide } \\
\text { button cells } \\
\text { batteries }\end{array}$ & $4 \mathrm{~kg} / \mathrm{t}$ & & $9 \mathrm{t} / \mathrm{y}$ & \\
\hline
\end{tabular}


Table 35 (continued)

\begin{tabular}{|c|c|c|c|c|}
\hline Source & $\begin{array}{l}\text { Input } \\
\text { Factor }\end{array}$ & Reference & Activity Rate & Reference \\
\hline $\begin{array}{l}\text { Production and } \\
\text { Use of Electrical } \\
\text { Switches and } \\
\text { Relays with } \\
\text { Mercury }\end{array}$ & $\begin{array}{c}0.07 \\
\text { g/person.ye } \\
\text { ar }\end{array}$ & (UNEP-CB, 2012) & $\begin{array}{c}72698000 \\
\text { people }\end{array}$ & $\begin{array}{l}\text { (UNEP-CB, } \\
\text { 2012) }\end{array}$ \\
\hline $\begin{array}{l}\text { Use of Dental } \\
\text { Amalgam Fillings }\end{array}$ & $\begin{array}{c}0.2 \\
\text { g/person.ye } \\
\text { ar }\end{array}$ & (UNEP-CB, 2012) & $\begin{array}{c}72698000 \\
\text { people }\end{array}$ & $\begin{array}{l}\text { (UNEP-CB, } \\
\text { 2012) }\end{array}$ \\
\hline \multirow{2}{*}{$\begin{array}{l}\text { Use of medical } \\
\text { blood pressure } \\
\text { gauges }\end{array}$} & \multirow{2}{*}{$80 \mathrm{~g} /$ item } & \multirow{2}{*}{ (UNEP-CB, 2012) } & $\begin{array}{l}29960 \text { health } \\
\text { care org. }\end{array}$ & (TSI, 2013b) \\
\hline & & & 1 item/ 6 years & $\begin{array}{c}\text { Personal } \\
\text { communication }\end{array}$ \\
\hline $\begin{array}{l}\text { Use of manometers } \\
\text { and gauges }\end{array}$ & $\begin{array}{c}0.005 \\
\text { g/person }\end{array}$ & (UNEP-CB, 2012) & $\begin{array}{c}72698000 \\
\text { people }\end{array}$ & $\begin{array}{l}\text { (UNEP-CB, } \\
\text { 2012) }\end{array}$ \\
\hline $\begin{array}{l}\text { Use of mercury in } \\
\text { laboratories }\end{array}$ & $\begin{array}{c}0.01 \\
\text { g/person }\end{array}$ & (UNEP-CB, 2012) & $\begin{array}{c}72698000 \\
\text { people }\end{array}$ & $\begin{array}{l}\text { (UNEP-CB, } \\
\text { 2012) }\end{array}$ \\
\hline \multicolumn{5}{|l|}{ Cemeteries } \\
\hline Cemeteries & $\begin{array}{c}2.5 \\
\text { g/corpse } \\
\end{array}$ & (UNEP-CB, 2012) & $\begin{array}{l}375000 \\
\text { people }\end{array}$ & (TSI, 2013a) \\
\hline \multicolumn{5}{|l|}{ General Waste } \\
\hline $\begin{array}{l}\text { Incineration of } \\
\text { Hazardous Waste }\end{array}$ & $24 \mathrm{~g} / \mathrm{t}$ & (UNEP-CB, 2012) & $42750 \mathrm{t} / \mathrm{y}$ & (TSI, 2013c) \\
\hline $\begin{array}{l}\text { Incineration and } \\
\text { Open Burning of } \\
\text { Medical Waste }\end{array}$ & $24 \mathrm{~g} / \mathrm{t}$ & (UNEP-CB, 2012) & $20695 \mathrm{t} / \mathrm{y}$ & (TSI, 2013c) \\
\hline $\begin{array}{l}\text { Sewage Sludge } \\
\text { Incineration }\end{array}$ & $2 \mathrm{~g} / \mathrm{t}$ & (UNEP-CB, 2012) & $8335 \mathrm{t} / \mathrm{y}$ & (MoEU, 2012a) \\
\hline $\begin{array}{l}\text { Open Fire Waste } \\
\text { Burning }\end{array}$ & $5 \mathrm{~g} / \mathrm{t}$ & (UNEP-CB, 2012) & $134000 \mathrm{t} / \mathrm{y}$ & (TSI, 2013c) \\
\hline $\begin{array}{l}\text { Controlled } \\
\text { Landfills/Deposits }\end{array}$ & $0.48 \mathrm{~g} / \mathrm{t}$ & Present Study & 24329096 t/y & (TSI, 2013c) \\
\hline $\begin{array}{l}\text { Informal Dumping } \\
\text { of General Waste }\end{array}$ & $5 \mathrm{~g} / \mathrm{t}$ & (UNEP-CB, 2012) & $200000 \mathrm{t} / \mathrm{y}$ & (TSI, 2013c) \\
\hline $\begin{array}{l}\text { Waste Water } \\
\text { System/Treatment }\end{array}$ & $\begin{array}{c}0.63 \\
\mathrm{mg} / \mathrm{m} 3\end{array}$ & Present Study & $\begin{array}{c}2719151000 \\
\mathrm{~m}^{3} / \mathrm{y}\end{array}$ & (TSI, 2013c) \\
\hline
\end{tabular}

